\section{Pacific Northwest}

National Laboratory

Operated by Battelle for the

U.S. Department of Energy

\title{
Summary of Hanford Subsurface Air Flow and Extraction (SAFE) Activities for Fiscal Year 2002
}

\author{
RJ Cameron \\ JC Evans \\ MD Johnson \\ TL Liikala
}

March 2002

Prepared for the U.S. Department of Energy under Contract DE-AC06-76RL01830 


\title{
DISCLAIMER
}

This report was prepared as an account of work sponsored by an agency of the United States Government. Neither the United States Government nor any agency thereof, nor Battelle Memorial Institute, nor any of their employees, makes any warranty, express or implied, or assumes any legal liability or responsibility for the accuracy, completeness, or usefulness of any information, apparatus, product, or process disclosed, or represents that its use would not infringe privately owned rights. Reference herein to any specific commercial product, process, or service by trade name, trademark, manufacturer, or otherwise does not necessarily constitute or imply its endorsement, recommendation, or favoring by the United States Government or any agency thereof, or Battelle Memorial Institute. The views and opinions of authors expressed herein do not necessarily state or reflect those of the United States Government or any agency thereof.

\author{
PACIFIC NORTHWEST NATIONAL LABORATORY \\ operated by \\ BATTELLE \\ for the \\ UNITED STATES DEPARTMENT OF ENERGY \\ under Contract DE-ACO6-76RLO183O
}

Printed in the United States of America

$$
\begin{aligned}
& \text { Available to DOE and DOE contractors from the } \\
& \text { Office of Scientific and Technical Information, } \\
& \text { P.O. Box 62, Oak Ridge, TN 37831-0062; } \\
& \text { ph: (865) 576-8401 } \\
& \text { fax: (865) 576-5728 } \\
& \text { email: reports@adonis.osti.gov }
\end{aligned}
$$

\footnotetext{
Available to the public from the National Technical Information Service, U.S. Department of Commerce, 5285 Port Royal Rd., Springfield, VA 22161 ph: (800) 553-6847 fax: (703) 605-6900 email: orders@ntis.fedworld.gov online ordering: http://www.ntis.gov/ordering.htm
} 


\title{
Summary of Hanford Subsurface Air Flow and Extraction (SAFE) Activities for Fiscal Year 2001
}

\author{
RJ Cameron \\ JC Evans \\ MD Johnson \\ TL Liikala
}

March 2002

\author{
Prepared for \\ the U.S. Department of Energy \\ under Contract DE-AC06-76RL01830 \\ Pacific Northwest National Laboratory \\ Richland, WA 99352
}




\section{Executive Summary}

Potential leak detection, monitoring, and mitigation (LDMM) techniques are being developed to support Hanford single-shell tank (SST) retrieval operations. In July and August 2001, Pacific Northwest National Laboratory (PNNL) demonstrated LDMM technologies for CH2M HILL Hanford Group, Inc. (CHG) at the Mock Tank Site in the 200 East Area as part of a tank leak detection demonstration (TLDD). These subsurface air flow and extraction technologies (collectively referred to as SAFE) use air injection and extraction wells, creating an advective air flowfield beneath a tank. SAFE includes the following nine technologies:

Leak detection: in-tank tracers, flowfield disturbance, radon displacement, and tank waste vapor

Leak monitoring: the partitioning tracer and reactive tracer methods

Leak mitigation: soil desiccation before and after leakage and in situ gaseous reduction

Subsurface characterization: interfacial tracers.

Of this suite of technologies, four were demonstrated in fiscal year (FY) 2001: in-tank tracers, flowfield disturbance, the partitioning tracer method, and soil desiccation. This report provides an overview of these SAFE technologies and describes the FY 2001 Mock Tank Site demonstration activities and results.

TLDD Activities at the Mock Tank Site were organized around four scheduled injections of a leak simulant solution that was allowed to drain into the subsurface via an access point in the center of the tank. A total of 3495 gal was leaked. At the time, the first and third injections were blind.

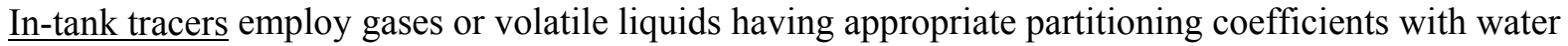
and brine to allow transport with a tank waste and the ability to be readily stripped from the leaked tank waste by a subsurface air flowfield. The concept is for tracers to be added to the tank during waste dissolution operations. Detection in the subsurface advective flow stream indicates a tank leak. The intank tracers used in FY 2001 include nitrous oxide, difluoromethane, and chlorodifluoromethane. Although the in-tank tracer method is under development and the testing used a different protocol, leak detection was achieved by this method all three times after only 135, 120, and 150 gal of solution entered the subsurface. Based on the field testing results and additional laboratory experiments and method development, realistic leak detection sensitivity using the in-tank tracer method could ultimately be in the range of 10 to 100 gal for a full-size SST. However, this depends on several factors, including hydraulic flow and transport properties not fully evaluated in the FY 2001 program.

Flowfield disturbance is a leak detection technology based on changes in subsurface air flow behavior due to changes in pneumatic conductivity that result from liquid infiltrating into the subsurface. Conservative tracers such as methane and pentafluoroethane are used. The tracer elution curves are analyzed for perturbations resulting from leak-induced porosity changes in the swept pore volume under a tank. Varying arrival times or multiple-peaked curves relative to baseline conditions are indicative of a leak. Flowfield disturbance was added to the test program at the end of the planning phase and thus was not a 
mature or optimized procedure at the time of testing. Comparison of three test series from FY 2001 showed definite trends of decreasing pneumatic permeability in all three test zones associated with three simulated leaks. These conclusions are very promising, but they are somewhat tentative because there was no well-established baseline prior to introduction of fluids into the subsurface.

The partitioning tracer method uses the principle of chromatographic separation through partitioninginduced flow retardation between partitioning and conservative (non-partitioning) tracers to quantify substances of interest in the swept zone. As applied to leak detection and monitoring, elution curves of tracer concentration are subjected to first-temporal-moment analysis to provide quantitative information on the leaked tank waste. The method is well established in the oil fields and for non-aqueous phase liquid (NAPL) characterization. In FY 2001, four tests were completed. Evaluating the data was difficult for several reasons, primarily the low-partitioning behavior of the tracer in the brine solution and the lack of usable baseline measurements from the site prior to solution injection. Further development work is necessary to identify and test tracers with adequate partitioning behavior in brine solution.

Soil desiccation showed the viability of using the subsurface air flow system for removing moisture from underneath a tank, thus functioning as a leak mitigation technology. During the leak detection testing and subsequent two-week soil desiccation testing, more than 1,000 gal of water were extracted from the subsurface by the air flow systems.

The remaining technologies are less mature than these four but share a commonality in using a subsurface flowfield. The complete package of nine complementary SAFE technologies truly offers unique LDMM capabilities. The path forward does, however, require varying levels of technology development and testing to be ready for eventual tank farm deployment. Future activities should include laboratory testing, field demonstration, and predictive model refinement to ensure a successful program. 


\section{Acknowledgments}

The authors wish to acknowledge the important roles of the following people in this project: P. A. Gauglitz, J. W. Brothers, D. P. Mendoza, B. J. Devary, A. V. Mitroshkov, R. Schalla, and D. C. Lanigan, all of PNNL; G. A. Pope of the University of Texas-Austin; D. Yonge of Washington State University; and F. J. Holzmer, J. T. Londergan, M. Q. Jin, K. Gordon, J. C. Silva, and H. C. Linnemeyer of Duke Engineering and Services of Austin, Texas. We also thank K. B. Olsen (PNNL) for his helpful technical review and S. Q. Bennett for her editorial review and document assembly. 


\section{Abbreviations and Acronyms}

$\begin{array}{ll}\text { bgs } & \text { below ground surface } \\ \text { CHG } & \text { CH2M HILL Hanford Group, Inc. } \\ \text { CITT } & \text { conservative interwell tracer test } \\ \text { CPT } & \text { cone penetrometer } \\ \text { DOE } & \text { U.S. Department of Energy } \\ \text { ECD } & \text { electron capture detector } \\ \text { EMSP } & \text { Environmental Management Science Program } \\ \text { ERT } & \text { electrical resistance tomography } \\ \text { FID } & \text { flame ionization detector } \\ \text { FY } & \text { fiscal year } \\ \text { GC } & \text { gas chromatograph } \\ \text { GC/MS } & \text { gas chromatography/mass spectrometry } \\ \text { IG } & \text { infiltration gallery } \\ \text { ILL } & \text { interstitial liquid level } \\ \text { ISGR } & \text { in situ gaseous reduction } \\ \text { ITTT } & \text { in-tank tracer test } \\ \text { LDMM } & \text { leak detection, monitoring, and mitigation } \\ \text { MDL } & \text { method detection level } \\ \text { NAPL } & \text { non-aqueous phase liquid } \\ \text { PITT } & \text { partitioning interwell tracer test } \\ \text { PNNL } & \text { Pacific Northwest National Laboratory } \\ \text { ppbv } & \text { parts per billion by volume } \\ \text { ppmv } & \text { parts per million by volume } \\ \text { pptv } & \text { parts per trillion by volume } \\ \text { RH } & \text { relative humidity } \\ \text { RTD } & \text { residence time distribution } \\ \text { SAFE } & \text { subsurface air flow and extraction } \\ \text { SST } & \text { single-shell tank } \\ \text { TDA } & \text { technology development area } \\ \text { TLDD } & \text { tank leak detection demonstration } \\ \text { UT-Austin } & \text { University of Texas-Austin } \\ & \end{array}$




\section{Contents}

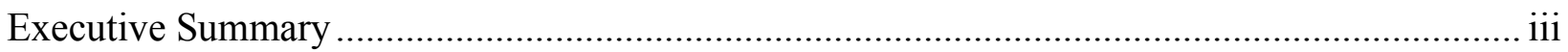



Abbreviations and Acronyms ……………………................................................................ vii



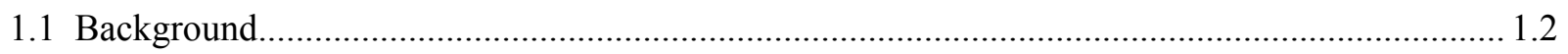

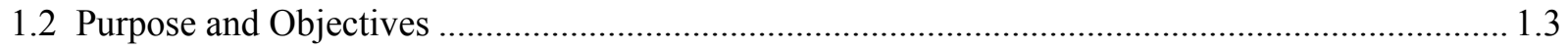

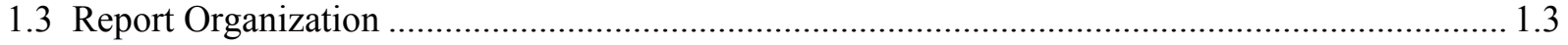







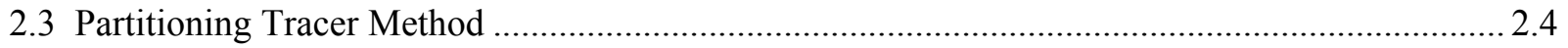

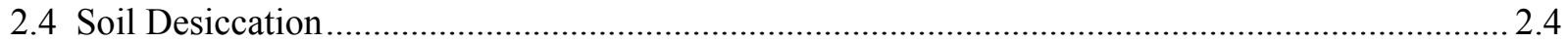

3.0 Laboratory Studies .............................................................................................

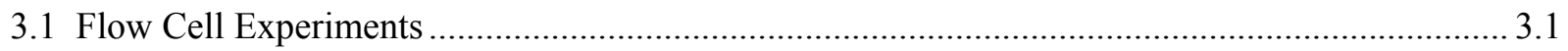

3.2 Tracer Behavior under Fast-Flow Conditions …………………………………………..... 3.8

3.3 Tracer Partitioning Characteristics in Saline Solutions ............................................................... 3.9





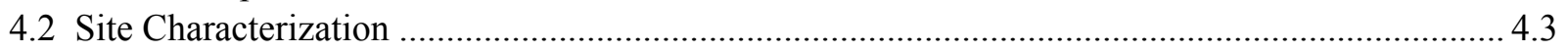

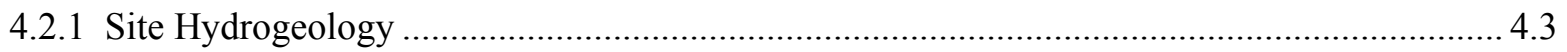

4.2.2 Grain-Size Distribution and Hydraulic/Pneumatic Conductivity.............................................. 4.3

4.2.3 Background Soil-Moisture Measurements...………………………………………….... 4.3

4.2.4 Sodium Thiosulfate Infiltration Test................................................................................. 4.5

4.3 Modifications to Technology Development Area ………………………………………....... 4.7

4.4 Modifications to Mock Tank Structure …………………………………………………......... 4.7

4.5 Instrumentation and Equipment............................................................................................... 4.7

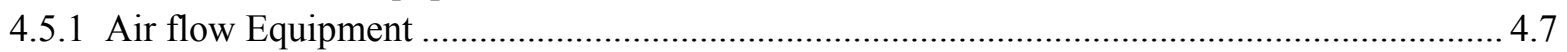



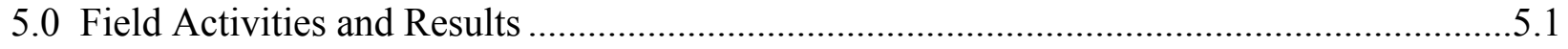

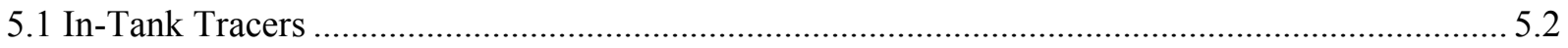

5.1.1 Nitrous Oxide In-Tank Tracer Test at Technology Development Area................................... 5.2

5.1.2 Difluoromethane/Pentafluoroethane In-Tank Tracer Test at Mock Tank Structure ................ 5.3

5.1.3 Chlorodifluoromethane In-Tank Tracer Test at Mock Tank Structure ................................... 5.5



5.1.5 Use of In-Tank Tracers for Tank Farm Deployment ......................................................... 5.7

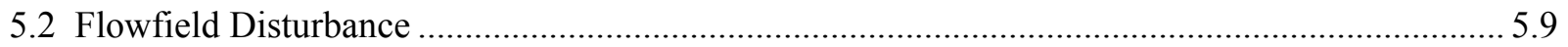








6.0 Implications for SAFE Technology Usage in SST Retrieval, Closure, Post-Closure ...........6.1



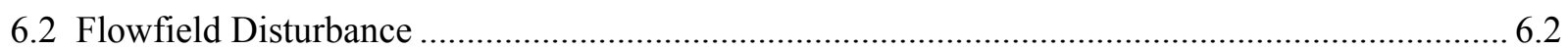





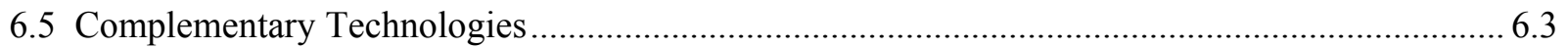

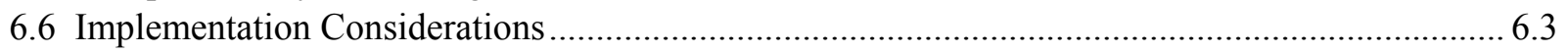

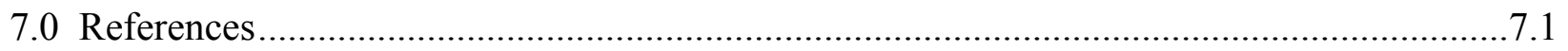

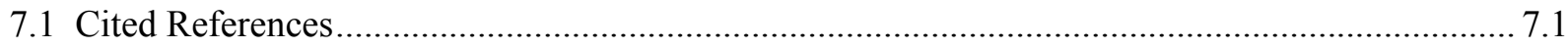

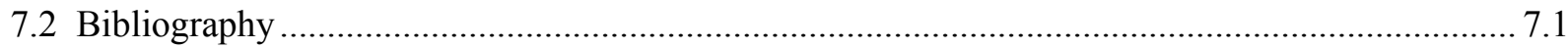

Appendix A: PITT Technology for Tank Leak Detection: FY 2001 Field

Demonstration Test Plan ............................................................................ 1

Appendix B: Supplemental Laboratory Study Data ...................................................... B. 1

Appendix C: Estimated Hydraulic and Pneumatic Conductivities for the Mock Tank

Site Based on Geology, Lithology, and Grain-Size Analyses ............................. 1

Appendix D: Supplemental Partitioning Tracer Data from the Mock Tank Structure.............D.1

Appendix E: Complementary SAFE Technologies …................................................. E. 1

Appendix F: $\quad$ Detailed Chronology of SAFE Events Conducted in FY 2001 ........................ F.1 


\section{Figures}



2.1 Subsurface Flowfield Common to SAFE Technologies .......................................................... 2.2

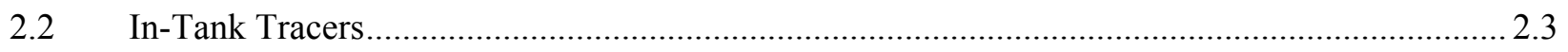

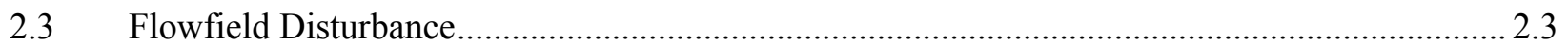



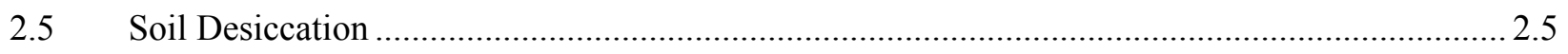

3.1 Schematic Representation of 2-D Flow Cell Showing Basic Operation.................................... 3.2

3.2 2-D Flow Cell with Inlet Humidifier, Vacuum Pump, and Mass Flow Controller....................... 3.2

3.3. Tracer Response Curve for $\mathrm{SF}_{6}$ Tracer Through 2-D Flow Cell Prior to Liquid Being

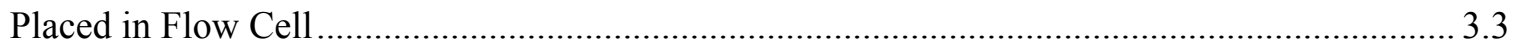

3.4 Tracer Response Curves for $\mathrm{SF}_{6}$ and Difluoromethane Tracer Test Through 2-D Flow

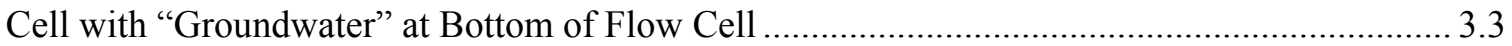

3.5 Excavation of "Leak" Plume Formed after Adding $100 \mathrm{~mL}$ Deionized Water to Silica Sand ..... 3.4

3.6 3-D Rendition of Water "Leak" Plume Introduced at the Top of a Silica Sand Column ............. 3.5

3.7 Tracer Response Curve: 0.19 L/min Flow, 120 mL Plume .................................................... 3.5

3.8 Tracer Response Curve: 0.10 L/min Flow, 120 mL "Leak" ..................................................... 3.6

3.9 Tracer Response Curve: 0.05 L/min Flow, 120 mL "Leak" ..................................................... 3.6

3.10 Tracer Response Curve: 0.19 L/min Flow, 200 mL "Leak" .................................................... 3.7

3.11 Tracer Response Curve: 0.10 L/min Flow, 200 mL "Leak" ................................................... 3.8

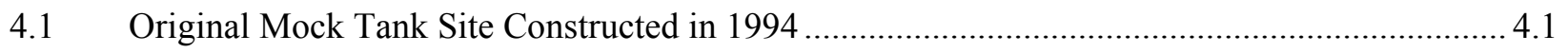

4.2 Map of Mock Tank Site Showing Mock Tank Structure and Technology Development Area.... 4.2

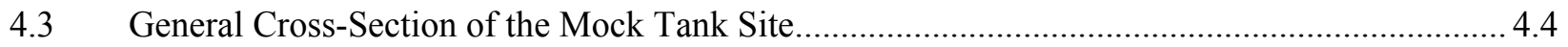

4.4 Soil-Water Saturation from Neutron Log, Gravimetric, and Volumetric Correlation .................. 4.5

4.5 Soil Moisture Volume Changes in IG Well C .......................................................................... 4.6

4.6 Soil Moisture Volume Changes in IG Well A ......................................................................... 4.6

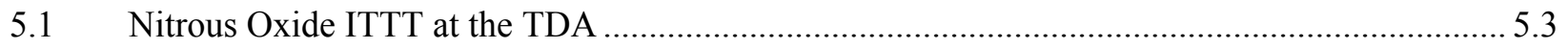

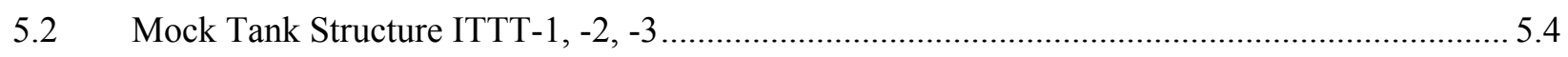

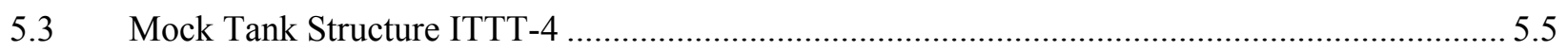

5.4 Partitioning Behavior of Difluoromethane and Chlorofluoromethane as a Function

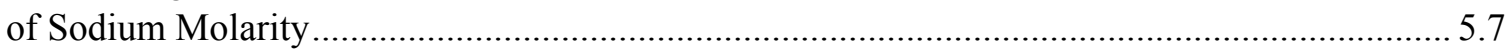

5.5 Methane Response at Monitoring Well 1020M ....................................................................... 5.10

5.6 Methane Response at Monitoring Well 2030M................................................................. 5.11

5.7 Methane Response at Monitoring Well 3040M.................................................................. 5.11

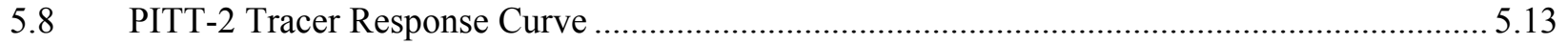

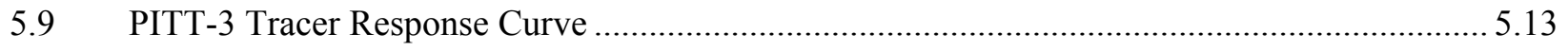






\section{Tables}

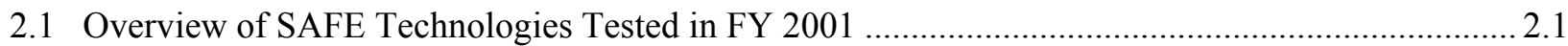

3.1 Results of Experiment with Groundwater and $120 \mathrm{~mL}$ "Leak" .................................................... 3.7

3.2 Results of Experiment with Groundwater and $200 \mathrm{~mL}$ "Leak" ..................................................... 3.8

4.1 Textural Groups and Corresponding Hydraulic and Pneumatic Conductivities .............................. 4.3

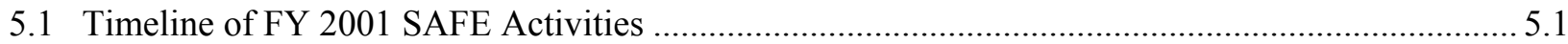

5.2 Summary of the First Moments of the Conservative Tracer Response Curves ............................ 5.12 


\subsection{Introduction}

Potential leak detection, monitoring, and mitigation (LDMM) techniques are being sought by $\mathrm{CH} 2 \mathrm{M}$ HILL Hanford Group, Inc. (CHG) to support single-shell tank (SST) retrieval operations. In July and August 2001, Pacific Northwest National Laboratory (PNNL) demonstrated leak detection technologies at the Mock Tank Site (Figure 1.1) for CHG as part of a Tank Leak Detection Demonstration (TLDD). Four subsurface air flow technologies and five geophysical techniques were demonstrated. The subsurface air flow technologies that were tested are in-tank tracers, flowfield disturbance, the partitioning tracer method, and soil desiccation. These four technologies, along with several complementary technologies that were not tested, are collectively referred to as subsurface air flow and extraction (SAFE) technologies. The technologies are unique in concept, but they share a commonality in using a subsurface air flowfield composed of air injection and extraction wells.

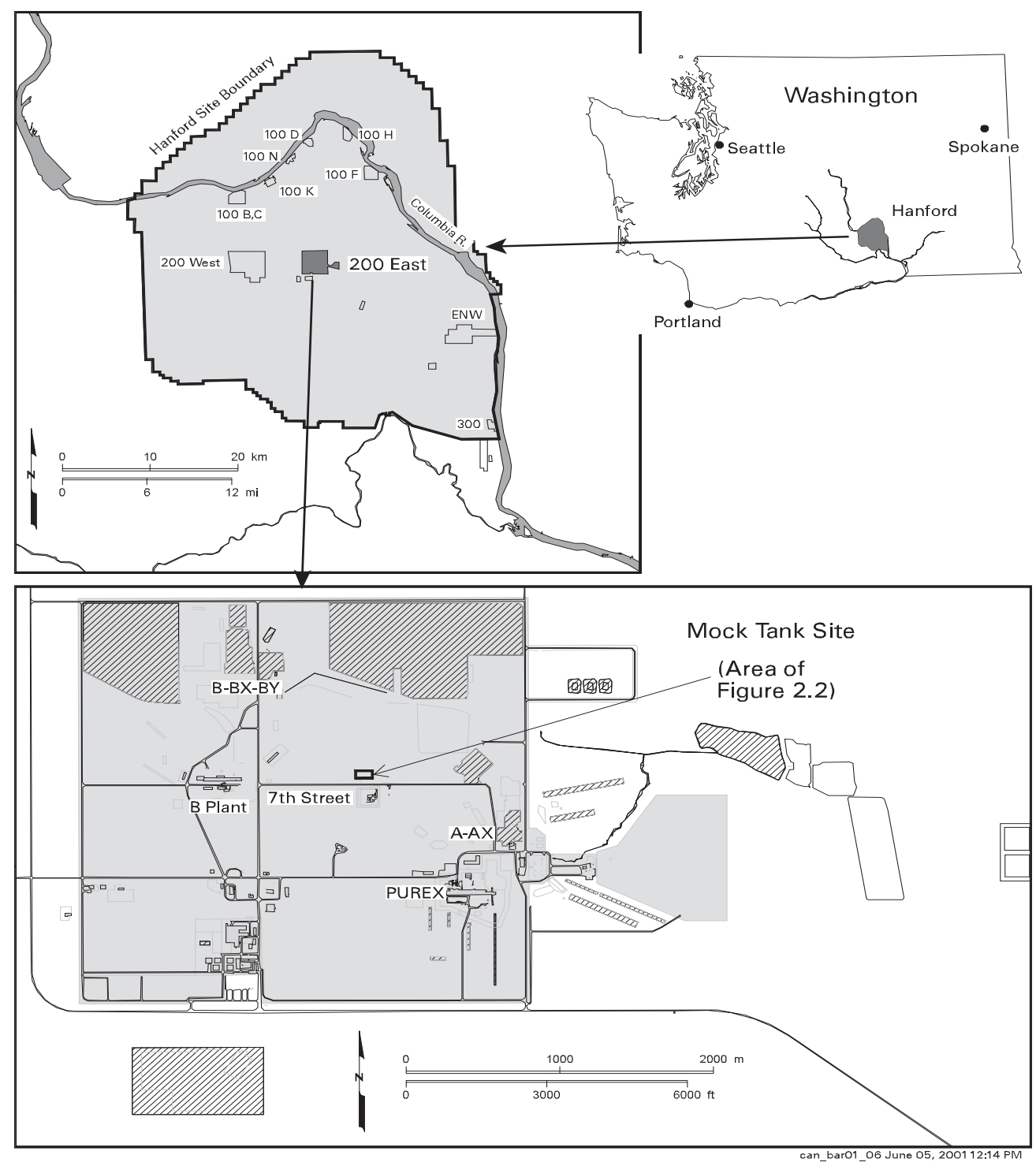

Figure 1.1. Mock Tank Site at Hanford 
The purpose of this report is to describe the SAFE technologies demonstrated during July and August 2001 and their results and implications for future work. Results for the five geophysical techniques are reported in Barnett et al. (2002). Additional background information, a summary of the demonstration purpose and objectives, and the organization of this report follow.

\subsection{Background}

In accordance with the M-45 series of milestones under the Hanford Federal Facility Agreement and Consent Order (Tri-Party Agreement) (Ecology et al. 1998), CHG will remove wastes from SSTs and other underground tanks for storage in the double-shell tank system. Pursuant to this, CHG is demonstrating several retrieval methods that use little, if any, additional liquid to dislodge, mobilize, and remove the wastes as alternatives to the past practice of sluicing. Tank wastes and conditions will be actively monitored during retrieval operations to ensure protection of the vadose zone beneath the SSTs. Hence, significant effort is being directed at devising detection, monitoring, and mitigation techniques for tank leakage.

CHG and their subcontractors have been evaluating several potential ex-tank (monitored from outside the tank) technologies so that LDMM will be available during waste retrieval operations. The ex-tank technologies are being examined in phases, beginning with the fiscal year (FY) 2001 demonstrations described in this report. These small, field-scale efforts were designed as "proof-of-concept" tests under vadose-zone conditions approaching those found in SST farms.

The SAFE concept originated with the partitioning tracer method as a volume-integrating technique for leak detection and monitoring. As such, it was initially referred to as "PITT" (partitioning interwell tracer test). The partitioning tracer method was developed in the oil industry and adapted to the environmental field for non-aqueous phase liquid (NAPL) detection (Deeds et al. 1999; Yoon et al. 1999). As the technology matured and was refined, it was eventually adapted for vadose zone soil moisture measurements. A strength of this technique is that it is a volume-integrating method rather than a point measurement or short depth of measurement along a single well. With the ability to measure soil moisture, concepts were developed for adapting the partitioning tracer method to Hanford SST leak detection.

In late 2000 and early 2001, a white paper ${ }^{(a)}$ was developed that explored the possibility of using the partitioning tracer method for leak detection and monitoring. This led to funding to develop the technology for detecting and monitoring leaks in the tanks. During the spring of 2001, the necessary activities were planned for developing the partitioning tracer technology for leak detection testing. Soon thereafter, it was determined that the partitioning tracer technology would be one of several technologies tested at the Mock Tank Site in a series of sodium thiosulfate solution leaks in the summer of 2001. As field activities progressed, several other subsurface air flow technologies were conceived. Thus PITT evolved into SAFE. Three of these SAFE technologies, in-tank tracers, flowfield disturbance, and soil desiccation, were also demonstrated in the field.

(a) Gauglitz, PA, RJ Cameron, JC Evans, MD Johnson, GA Pope, RE Jackson, H Meinardus, N Deeds, and E Bruesewitz. November 2001. Partitioning Interwell Tracer Test Technology Demonstration for Single-Shell Tank Leak Detection and Monitoring. Draft report, Pacific Northwest National Laboratory, Richland, Washington. 


\subsection{Purpose and Objectives}

The purpose of the TLDD was to perform initial field tests of potential LDMM technologies to enhance early leak detection capabilities during retrieval operations at the Hanford SSTs. Technologies using volume-integrating methods rather than point-source sensing methods were sought out for testing, although at least two of the technologies are point-of-release methods as implemented. Performance assessment, including determination of the lower limits of sensitivity, both minimum detectable effluent volume and time to detection, was the key objective. The TLDD was also intended to help identify potential interferences in detection capability and solute-retardation mechanisms resulting from infrastructure (transfer lines, pipes, electrical noise, etc.) likely to be present in SST environments. However, these interferences were somewhat limited at the Mock Tank Site because of the shallow tank depth and simple infrastructure.

\subsection{Report Organization}

This report is organized as follows. An overview of the SAFE technologies tested is provided in Section 2. Laboratory studies performed in support of this work are highlighted in Section 3. Site characterization and setup for the Mock Tank Site are discussed in Section 4, and Section 5 presents the field activities and results. Section 6 discusses SAFE technology usage for SST retrieval, closure, and post-closure. References cited in the text are listed in Section 7. The test plan for the FY 2001 work is included as Appendix A; supplemental laboratory study data can be found in Appendix B. Appendix C is a report on hydraulic and pneumatic conductivities at the Mock Tank Site; Appendix D presents supplemental partitioning tracer data from the Mock Tank Structure; Appendix E discusses complementary SAFE technologies; and Appendix F contains a detailed chronology of SAFE events conducted during FY 2001. 


\subsection{Overview of SAFE Technologies Tested}

Descriptions of the four primary SAFE technologies tested (in-tank tracers, flowfield disturbance, partitioning tracer method, and soil desiccation) and their applicability to LDMM for retrieval operations at the SSTs are provided in this section and listed in Table 2.1. The subsurface flowfield common to all of the technologies is illustrated in Figure 2.1. A fifth technology, in situ gaseous reduction (ISGR), has been successfully tested offsite and again recently in the laboratory. ISGR, along with the ancillary technologies, is discussed briefly in Section 6 and presented in more detail in Appendix E. These technologies are less mature than the first four and will require significantly more development efforts before field-testing or deployment can take place.

Table 2.1. Overview of SAFE Technologies Tested in FY 2001

\begin{tabular}{|c|c|c|c|c|c|c|c|}
\hline \multicolumn{8}{|c|}{ Applicability } \\
\hline Technology & Description & .0.气 & 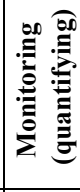 & : & Testing Status & Needs & Comments \\
\hline In-Tank Tracers & $\begin{array}{l}\text { Use of a gas or volatile liquid } \\
\text { having a strong partitioning } \\
\text { coefficient for distribution into } \\
\text { water/brine that is readily } \\
\text { stripped from the leaked solution } \\
\text { by a subsurface flowfield after } \\
\text { the leak has exited the tank }\end{array}$ & $\mathrm{X}$ & & & $\begin{array}{l}\text { Test using nitrous oxide and } \\
\text { water conducted at technol- } \\
\text { ogy development area; three } \\
\text { tests conducted at Mock Tank } \\
\text { Structure. Leaks detected } \\
\text { after } 135 \text { gal, } 120 \text { gal, and } \\
150 \text { gal entered subsurface. }\end{array}$ & $\begin{array}{l}\text { Ready to be field } \\
\text { demonstrated }\end{array}$ & $\begin{array}{l}\text { Candidates currently being } \\
\text { evaluated include } \\
\text { difluoromethane, } \\
\text { chlorodifluoromethane, } \\
\text { and nitrous oxide }\end{array}$ \\
\hline $\begin{array}{l}\text { Flowfield } \\
\text { Disturbance }\end{array}$ & $\begin{array}{l}\text { Change in pneumatic } \\
\text { conductivity resulting from } \\
\text { liquid flowing into the } \\
\text { subsurface }\end{array}$ & $\mathrm{X}$ & & & $\begin{array}{l}\text { Effect observed in effluent } \\
\text { behavior of tracers during FY } \\
2001 \text { demonstrations at the } \\
\text { Mock Tank Structure. Leaks } \\
\text { detected. }\end{array}$ & \begin{tabular}{|l|} 
Conservative tracer \\
experiments proposed \\
in conjunction with \\
soil drying box \\
experiments
\end{tabular} & $\begin{array}{l}\text { Initial box studies showed } \\
\text { flowfield effect when } \\
\text { liquid introduced into box }\end{array}$ \\
\hline \begin{tabular}{|l} 
Partitioning \\
Tracer Method
\end{tabular} & $\begin{array}{l}\text { Uses the principle of } \\
\text { chromatographic separation } \\
\text { through partitioning-induced } \\
\text { flow retardation of tracers to } \\
\text { quantify substances of interest in } \\
\text { the swept zone }\end{array}$ & $\mathrm{X}$ & $\mathrm{X}$ & & $\begin{array}{l}\text { Six tests conducted at Mock } \\
\text { Tank Structure in FY 2001; } \\
\text { tracers developed have low } \\
\text { partitioning coefficients in } \\
\text { high-saline, high-pH tank } \\
\text { wastes. Results inconclusive } \\
\text { due to lack of baseline data. }\end{array}$ & \begin{tabular}{|l|} 
Need to develop \\
tracers with higher \\
partitioning \\
coefficients for high- \\
saline, high pH \\
solutions
\end{tabular} & \begin{tabular}{|l|} 
Samples and integrates \\
over a large volume to \\
provide near real-time \\
quantitative data on leaked \\
tank-waste volume
\end{tabular} \\
\hline Soil Desiccation & $\begin{array}{l}\text { Soil drying through subsurface } \\
\text { air flow resulting in reduced } \\
\text { matric potential under a tank }\end{array}$ & & & $X$ & $\begin{array}{l}\text { Over 1,000 gal moisture } \\
\text { removed during FY } 2001 \\
\text { demonstration at mock-tank } \\
\text { structure }\end{array}$ & $\begin{array}{l}\text { Box experiments } \\
\text { proposed }\end{array}$ & $\begin{array}{l}\text { Heating and drying of } \\
\text { influent air aids desiccation } \\
\text { process }\end{array}$ \\
\hline
\end{tabular}

\subsection{In-Tank Tracers}

In-tank tracers (Figure 2.2) use gases or volatile liquids having appropriate partitioning coefficients with water and brine to allow transport with a tank waste and the ability to be readily stripped from the leaked tank waste by a subsurface air flowfield. The tracers are added to the tank during waste-dissolution operations. Detection of the tracer(s) in the advective flow stream indicates a leak, and an indication of the downward migration of a leak can be obtained by detection of the tracer at lower intervals. The partitioning coefficients must be low enough that the tracers will not be subject to exceptionally high 


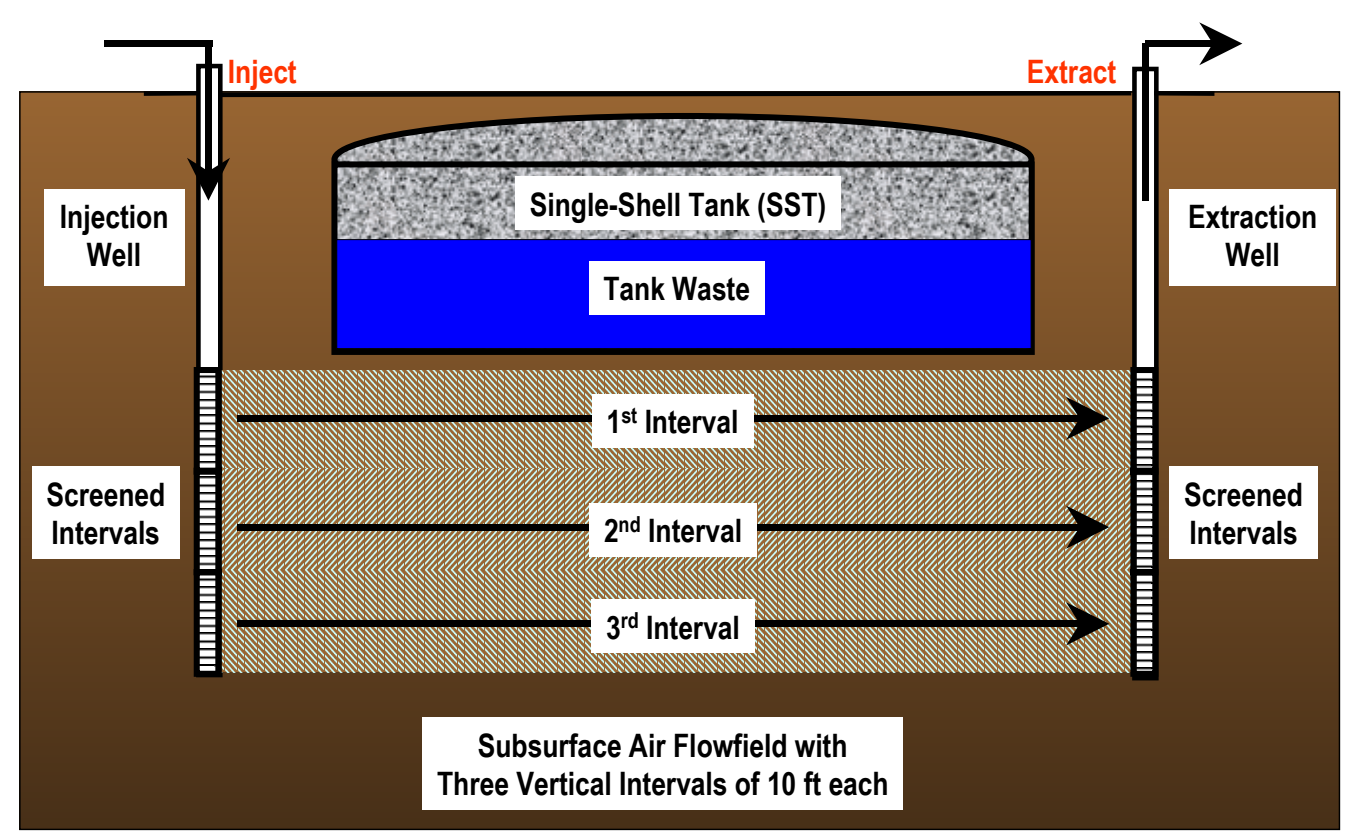

Figure 2.1. Subsurface Flowfield Common to SAFE Technologies

retardation due to soil moisture after they enter the gas phase beneath the tank. This criterion bounds the range of suitable partitioning coefficients from about 1 to 5 (dimensionless Henry's Law coefficient for strong partitioning into water). Because the high salt concentration present during saltcake removal reduces the solubility of these tracers by almost an order of magnitude compared with their solubility in pure water, the list of candidates is limited further. Difluoromethane, chlorodifluoromethane, and nitrous oxide are candidate in-tank tracers that have suitable characteristics for this application and have been laboratory and field tested. A fourth tracer, chlorofluoromethane, has also been shown to have ideal properties as an in-tank tracer It was not tested during FY 2001 because it was being used at the time as a partitioning tracer with the partitioning tracer method. A non-partitioning tracer, pentafluoroethane, was used to demonstrate that the detected tracer was associated only with liquid transport. (Only very low [ppb] levels of the non-partitioning tracer were detected in the flow stream compared with ppm levels of the partitioning tracer.)

\subsection{Flowfield Disturbance}

Flowfield disturbance (Figure 2.3) is a leak detection technology based on changes in subsurface air flow behavior due to changes in pneumatic conductivity that result from liquid infiltrating into the subsurface. Such changes result from liquid filling pore spaces or interaction of high-ionic-strength brines with clay minerals in the formation. The latter geochemical effect is longer term and is associated with a much larger volume of the subsurface. Conservative tracers such as methane, pentafluoroethane, neon, and helium are used. The tracer elution curves are analyzed for perturbations resulting from leak-induced porosity changes in the swept pore volume under a tank. Variations in arrival times or multiple-peaked curves relative to baseline conditions are indicative of a leak. Different "streamtubes" develop and tracers may arrive earlier or later than observed under baseline conditions because of the reduction in the soil pores through which air may flow. 


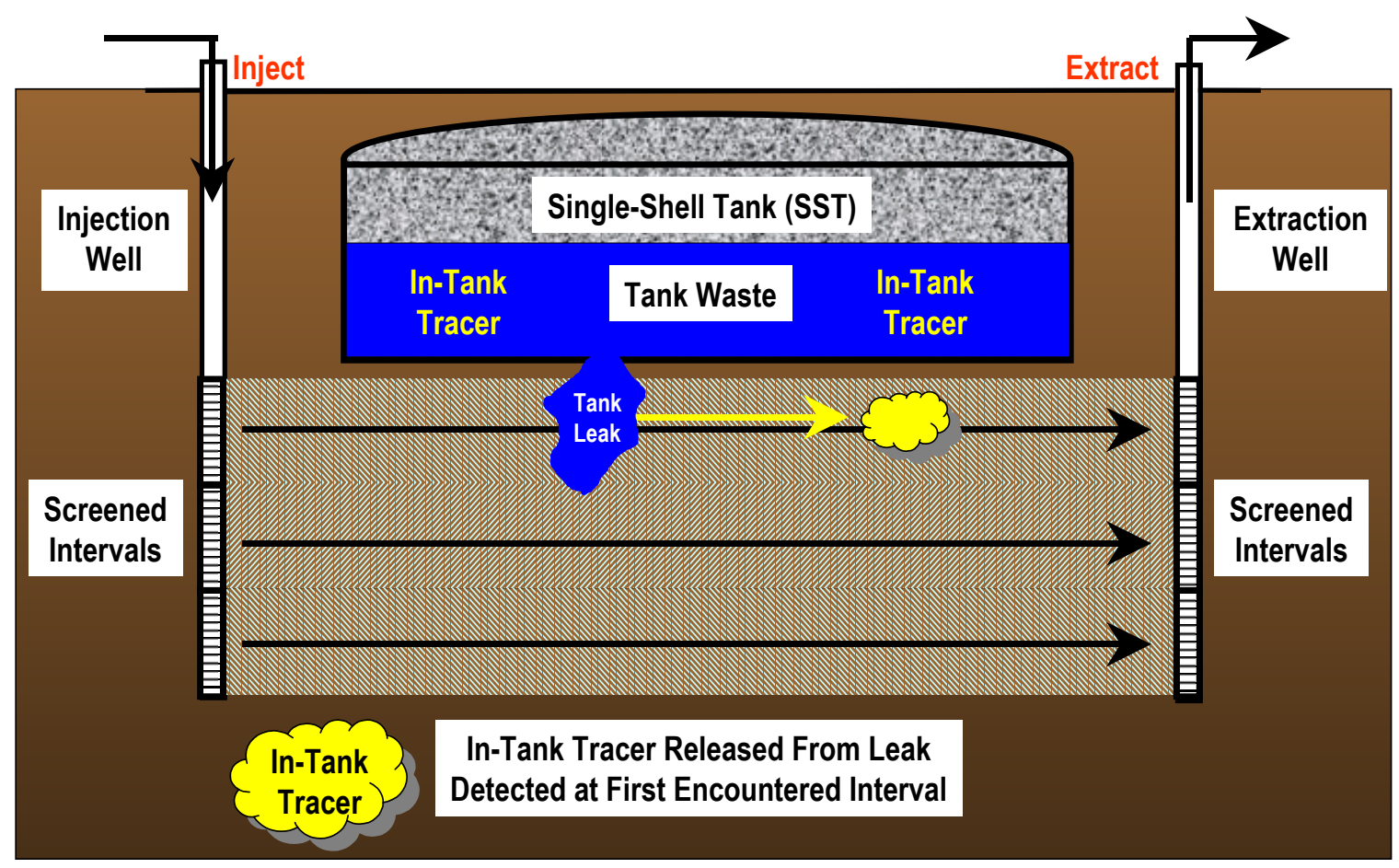

Figure 2.2. In-Tank Tracers

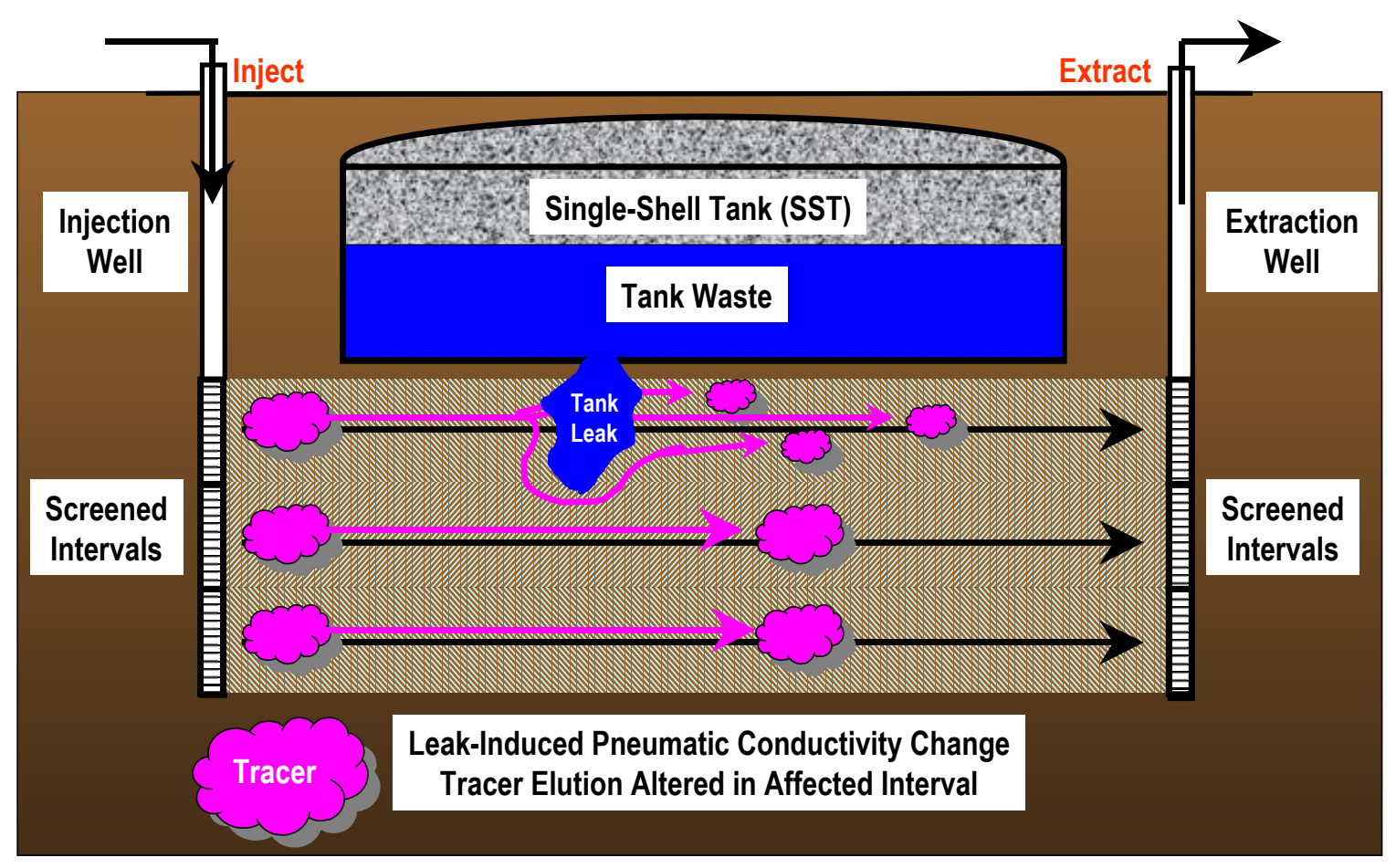

Figure 2.3. Flowfield Disturbance 


\subsection{Partitioning Tracer Method}

The partitioning tracer method (Figure 2.4) uses the principle of chromatographic separation through partitioning-induced flow retardation between partitioning and non-partitioning tracers to quantify substances of interest in the swept zone. As applied to leak detection and monitoring, elution curves of tracer concentration are subjected to first-temporal-moment analysis (centroid of the curve) to provide near-realtime quantitative information on the leaked tank waste. Inverse modeling codes can then be used to provide more detailed information on location and localized concentrations. This method is one of the few technologies for subsurface characterization that has the ability to sample and integrate over a large soil volume (thousands of cubic feet), eliminating the need for expensive "pincushion" monitoring arrays that often fail to achieve a representative sampling of the subsurface. The technology is also the only volume-integrating subsurface characterization technique that does not rely on electrical, electromagnetic, or other energy transduction methods, which are potentially subject to interference from subsurface or above-ground metallic objects such as tanks, pipes, or power lines. (Reactive tracers, which are a subset of the partitioning tracer method, are also a volume-integrating technique.)

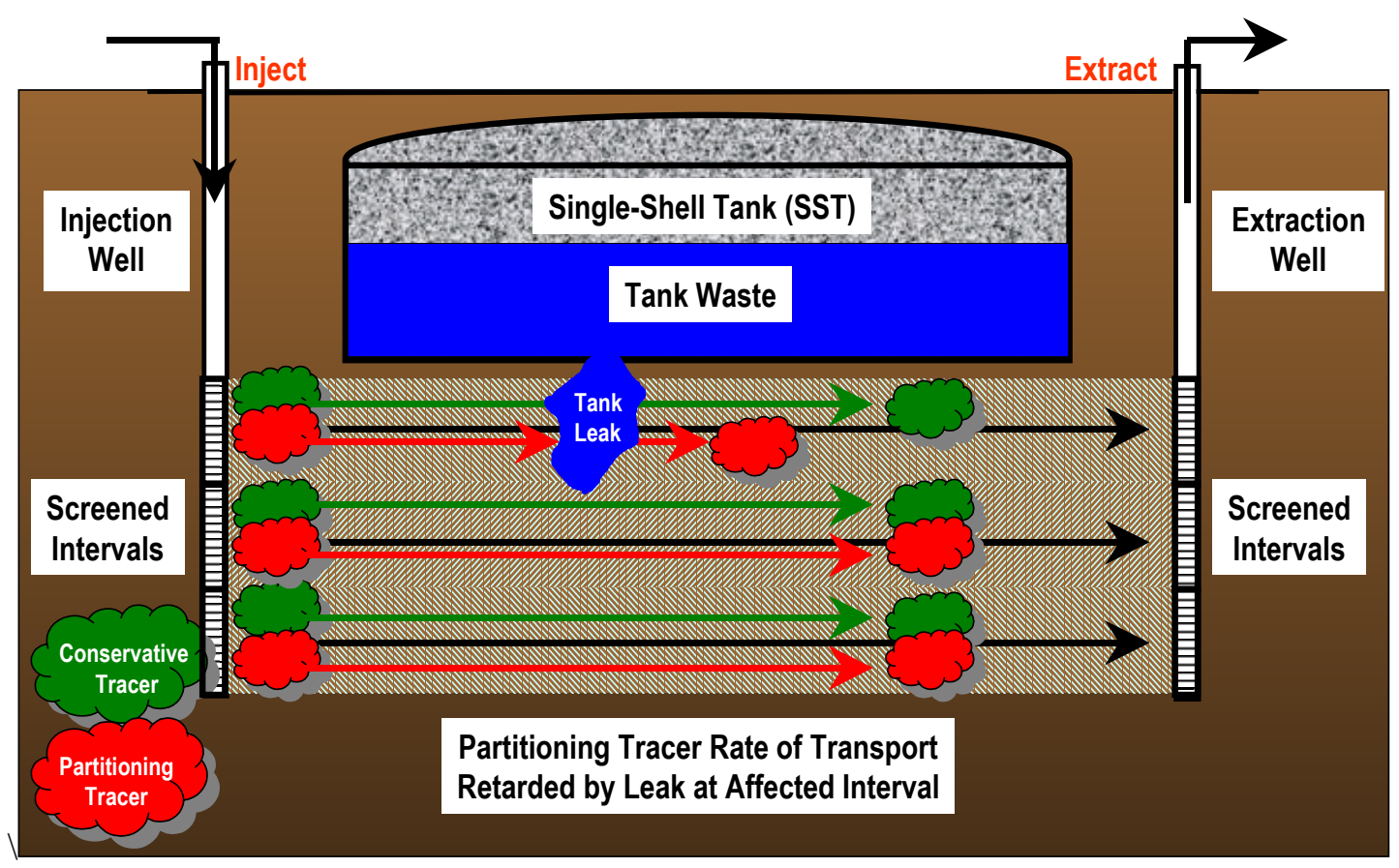

Figure 2.4. Partitioning Tracer Method

\subsection{Soil Desiccation}

Soil desiccation is a leak mitigation technique in which the matric potential under a tank is reduced through subsurface moisture removal. This is achieved by extracting moisture-laden air from underneath the tank. Soil drying can be enhanced by injecting dry air. Soil desiccation can be used to create a "dry" zone under a tank to provide increased uptake of any liquid that subsequently leaks and can also be used to remove moisture after a water leak has occurred. This approach should also enhance detection sensitivity for most leak detection methods, including other SAFE technologies and the geophysical methods, due to a greater contrast in subsurface moisture before and after a leak. 




Figure 2.5. Soil Desiccation 


\subsection{Laboratory Studies}

Three series of laboratory experiments were carried out as part of the partitioning tracer method activities for the TLDD:

- flow cell experiments characterizing tracer behavior in a two-dimensional (2-D) flowfield (Washington State University)

- packed-column experiments characterizing aqueous-partitioning tracer behavior under fastflow/nonequilibrium conditions (University of Texas-Austin [UT-Austin])

- packed-column experiments characterizing tracer partitioning coefficients in the presence of saturated salt solutions (PNNL/UT-Austin).

The results of the flow cell experiments are provided in detail below. Column experiment results are summarized in this section, and more detailed results are included in Appendix B.

\subsection{Flow Cell Experiments}

The primary focus of this experimental program was to test the efficacy of the partitioning tracer method under conditions that simulate the complex environment inherent in field situations. The general approach to the experimental program was to design and perform a series of experiments that start with well-defined, uncomplicated system conditions and add complexity as the experiments progress. Interpretation of the data at each step then afforded a means of adjusting the direction of the next set of experiments, if necessary. Each experiment used the 2-D flow cell (Figures 3.1 and 3.2).

The flow cell was filled with silica sand (F-35) for the first series of experiments in $8 \mathrm{~cm} \mathrm{lifts.} \mathrm{It} \mathrm{was}$ vibrated using a floor-mounted vibrator after the addition of each lift to compact the sand to a constant density. When the cell was full, a $0.6-\mathrm{cm}$ viton gasket and urethane sealant were placed around the perimeter, and the top was attached to make an airtight seal. Flow was initiated and controlled at a predetermined level to achieve a desired flow-through velocity. Both conservative (sulfur hexafluoride $\left[\mathrm{SF}_{6}\right]$ ) and nonconservative (difluoromethane) tracers were injected into the flow cell inlet in an impulse fashion, and effluent samples were collected frequently enough to accurately define the concentrationtime (C-t) profiles. The $\mathrm{SF}_{6}$ and difluoromethane were quantified using a gas chromatograph (GC) coupled with a six-port gas injection valve and $500-\mu \mathrm{L}$ injection loop. A $30-\mathrm{m}$ by $0.3-\mathrm{mm}$ column was used for compound separation. The flow was split at the terminal end of the column: $50 \%$ was delivered to an electron capture detector (ECD) for $\mathrm{SF}_{6}$ quantification and $50 \%$ to a flame ionization detector (FID) for difluoromethane quantification.

The first set of experiments was performed using $\mathrm{SF}_{6}$ under low relative humidity (RH) (room air at $\sim 30 \%$ ) and $100 \%$ RH. These tests were performed to evaluate the 2-D cell flow characteristics by defining the "reactor" dispersion number and actual residence time. 




Figure 3.1. Schematic Representation of 2-D Flow Cell Showing Basic Operation. Cell width is $15 \mathrm{~cm}$.

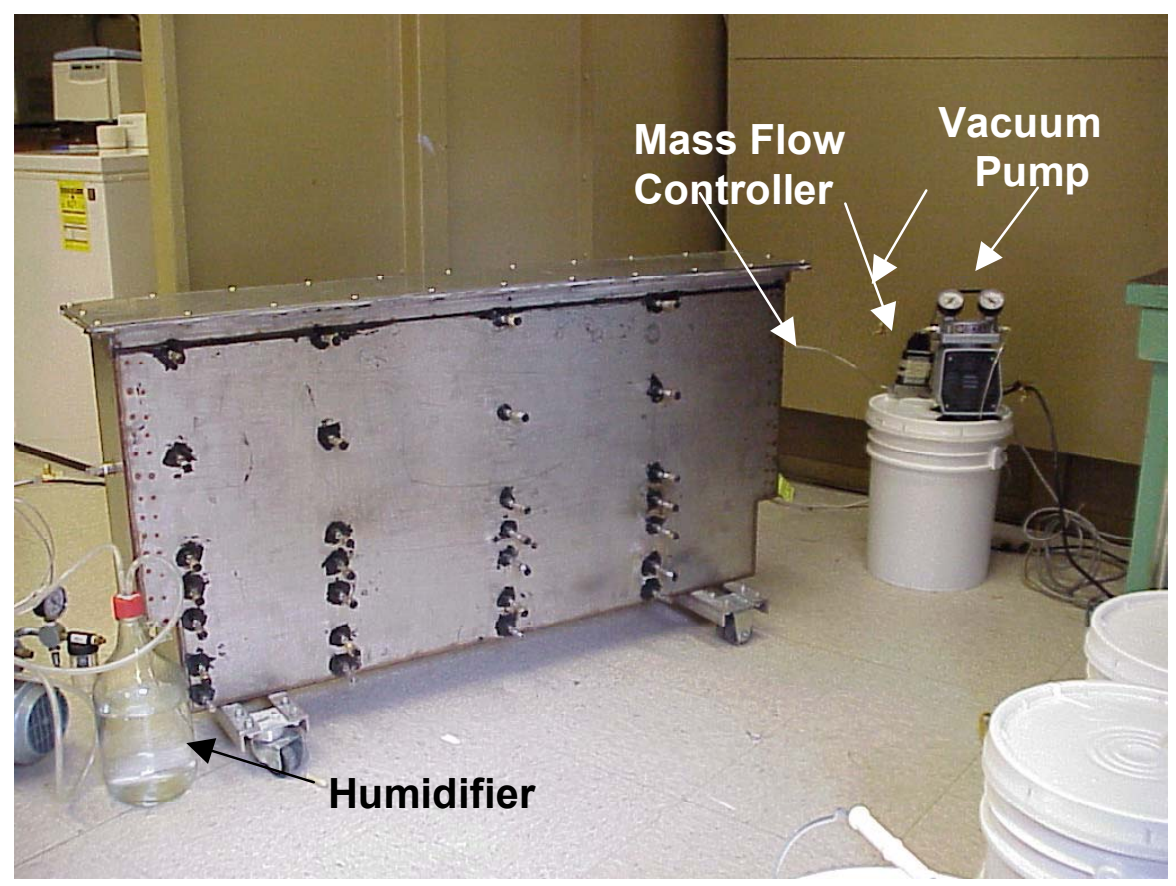

Figure 3.2. 2-D Flow Cell with Inlet Humidifier, Vacuum Pump, and Mass Flow Controller

The data in Figure 3.3 are representative of the residence time distributions (RTD) for the nonpartitioning tracer experiments. The actual flow cell residence time was determined to be 130 minutes and 131 minutes for the 30 and $100 \%$ RH runs, respectively. The actual residence time was calculated by determining the centroid of area under each RTD curve. These actual residence times compare well with the theoretical residence time of 134 minutes (based on the known flow rate, volume of cell, and a porosity of $40 \%$ ). The data were further evaluated by applying the N-Reactor in-series solution approach to 1) define the number of theoretical complete mix reactors that best simulates the tracer data and 2) define the reactor dispersion number (Levenspiel 1972). The data in Figure 3.3 indicate that this method of simulation results in a reasonable description of the tracer concentration profiles. 


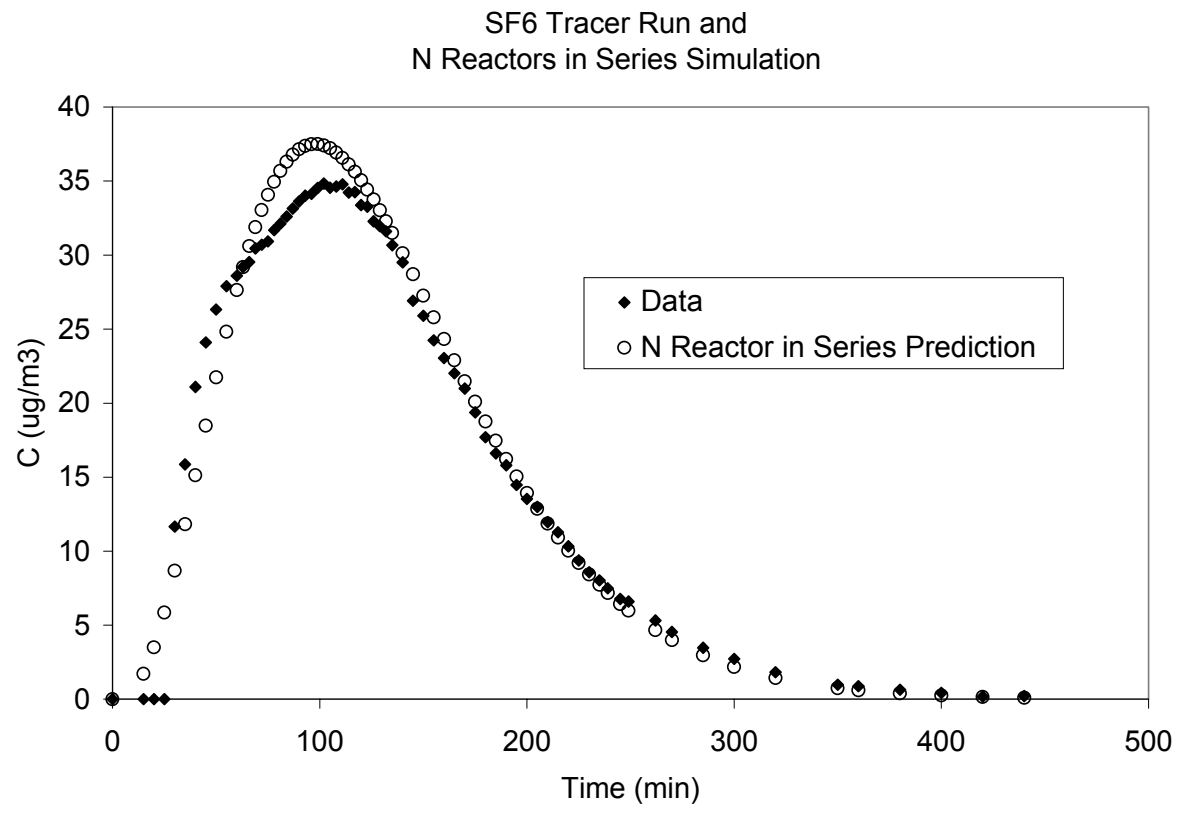

Figure 3.3. Tracer Response Curve for $\mathrm{SF}_{6}$ Tracer Through 2-D Flow Cell Prior to Liquid Being Placed in Flow Cell

A second set of experiments was performed using difluoromethane and $\mathrm{SF}_{6}$ over a range of flow rates and soil-water conditions. First, $8.1 \mathrm{~L}$ of deionized water was added to the bottom of the flow cell to fill the lower $15 \mathrm{~cm}$ to simulate the presence of groundwater. Tracer tests were performed on this system, and the C-t profiles are presented in Figure 3.4. The retardation factor for this system for difluoromethane was 0.99 .

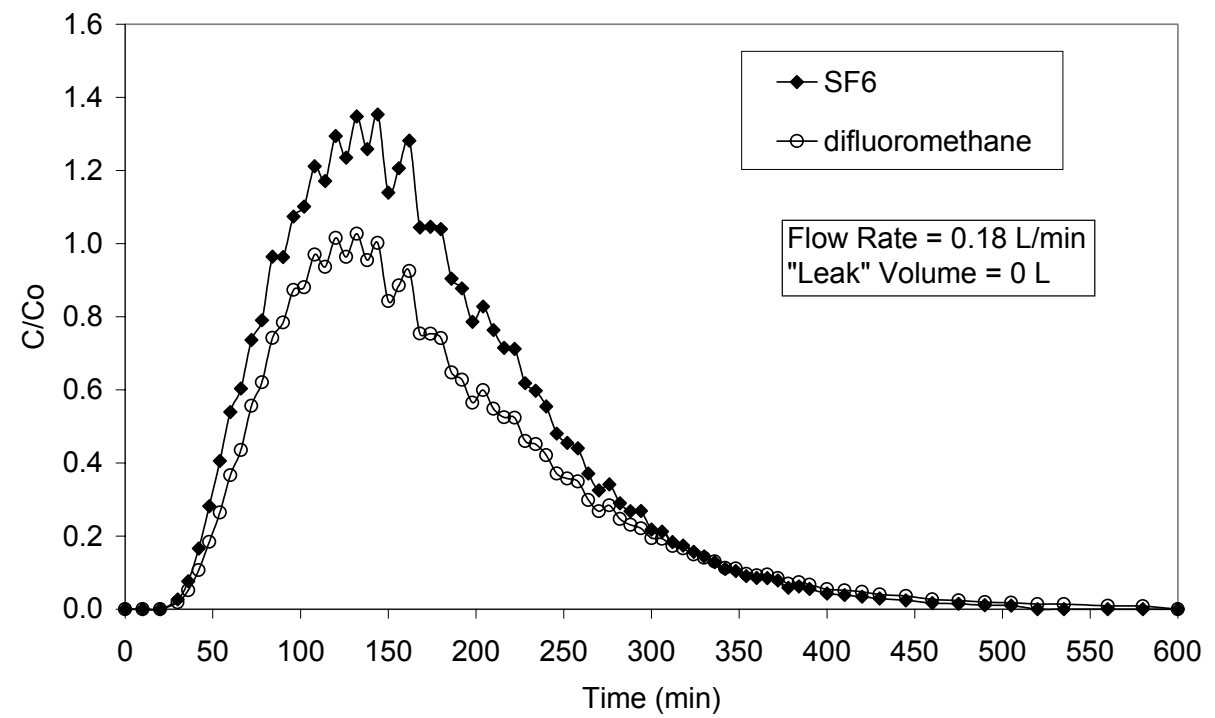

Figure 3.4. Tracer Response Curves for $\mathrm{SF}_{6}$ and Difluoromethane Tracer Test Through 2-D Flow Cell with "Groundwater" at Bottom of Flow Cell 
The next set of experiments involved adding a "leak" of water from the top of the flow cell at a point $61 \mathrm{~cm}$ from the cell inlet, and then repeating the tracer tests over a range of flow rates. The volume of water added for leak simulation was determined by performing a test in a Plexiglas column (Figure 3.5). After adding a preselected volume of water to the surface of silica sand in the column, the sand around the leak plume was carefully removed in $2-\mathrm{cm}$ lifts using a vacuum. After removal of each lift, measurements were taken to define the dimensions of the plume. A three-dimensional (3-D) plotting routine was then used to make a visual representation of the data to define leak plume geometry (Figure 3.6). Based on the results of this procedure, $120 \mathrm{~mL}$ of water were used to generate the first "leak" and then an additional $80 \mathrm{~mL}$ of water were used to repeat the tracer tests.

The data in Figures 3.7 through 3.9 are the results of the first set of experiments with a "leak" plume of $120 \mathrm{~mL}$ and the "groundwater" simulation condition. Tracer tests were performed at three flow rates: $0.19 \mathrm{~L} / \mathrm{min}, 0.10 \mathrm{~L} / \mathrm{min}$, and $0.05 \mathrm{~L} / \mathrm{min}$. The results, summarized in Table 3.1, show consistent retardation factors for the conservative tracer $\left(\mathrm{SF}_{6}\right.$; retardation factor $\left.=1.00\right)$ and the partitioning tracer (difluoromethane; retardation factor $=1.06$ to 1.07 ) independent of the air flow rate (from $0.05 \mathrm{~mL} / \mathrm{min}$ to $0.19 \mathrm{~mL} / \mathrm{min}$ ). It is also interesting to note the somewhat nonuniform track of the tracer data, especially compared with the data from the one-dimensional (1-D) column experiments. These relatively abrupt, but small, changes in concentration are thought to be a result of the changed nature of the air flowfield, resulting in flowfield "disturbances."

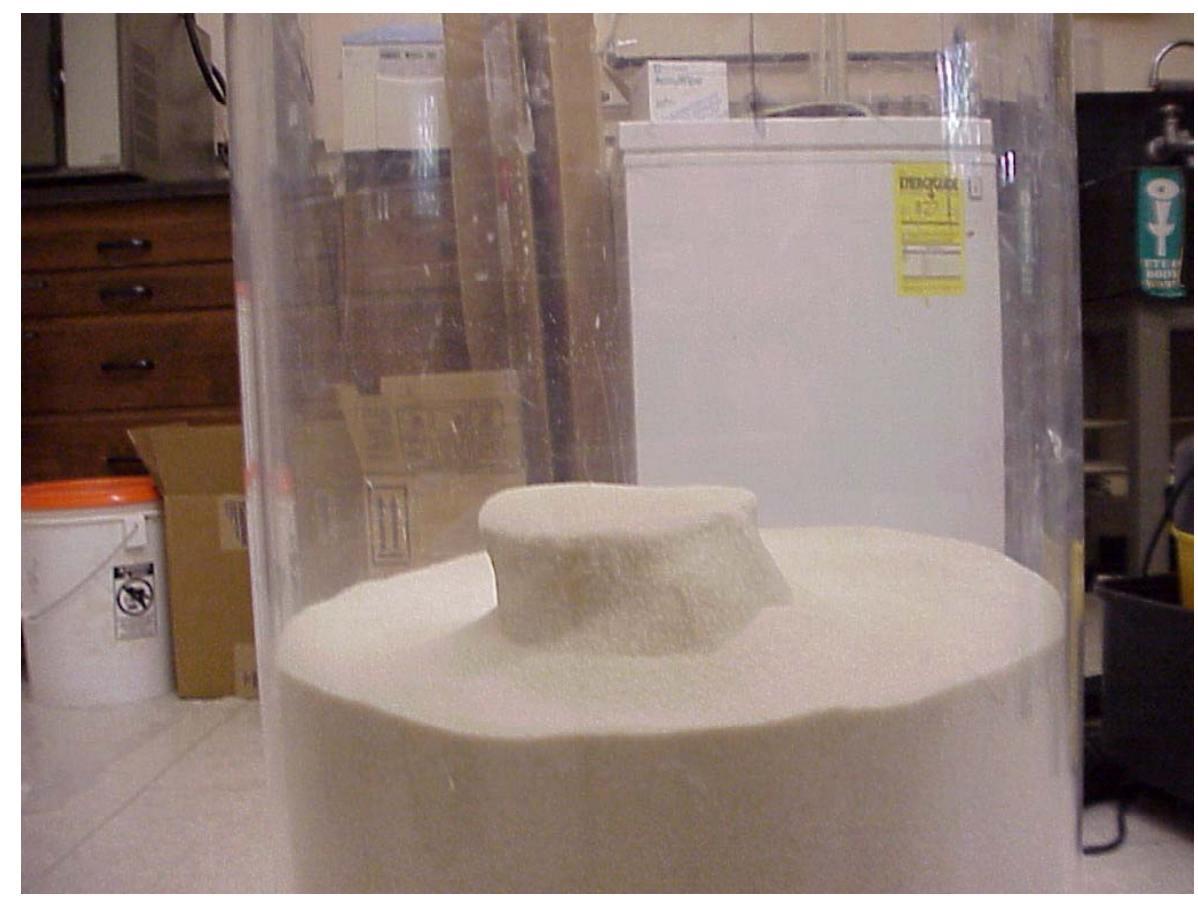

Figure 3.5. Excavation of "Leak" Plume Formed after Adding $100 \mathrm{~mL}$ Deionized Water to Silica Sand 


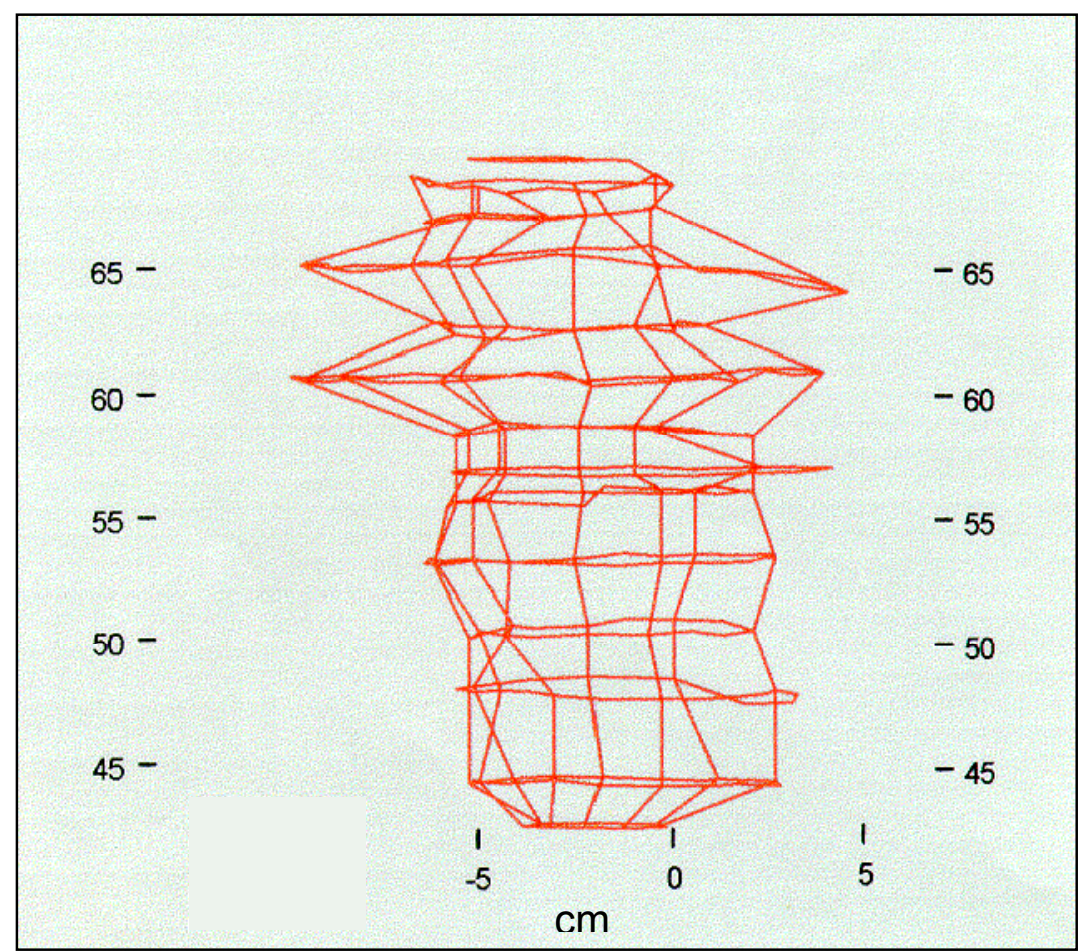

Figure 3.6. 3-D Rendition of Water "Leak" Plume Introduced at the Top of a Silica Sand Column

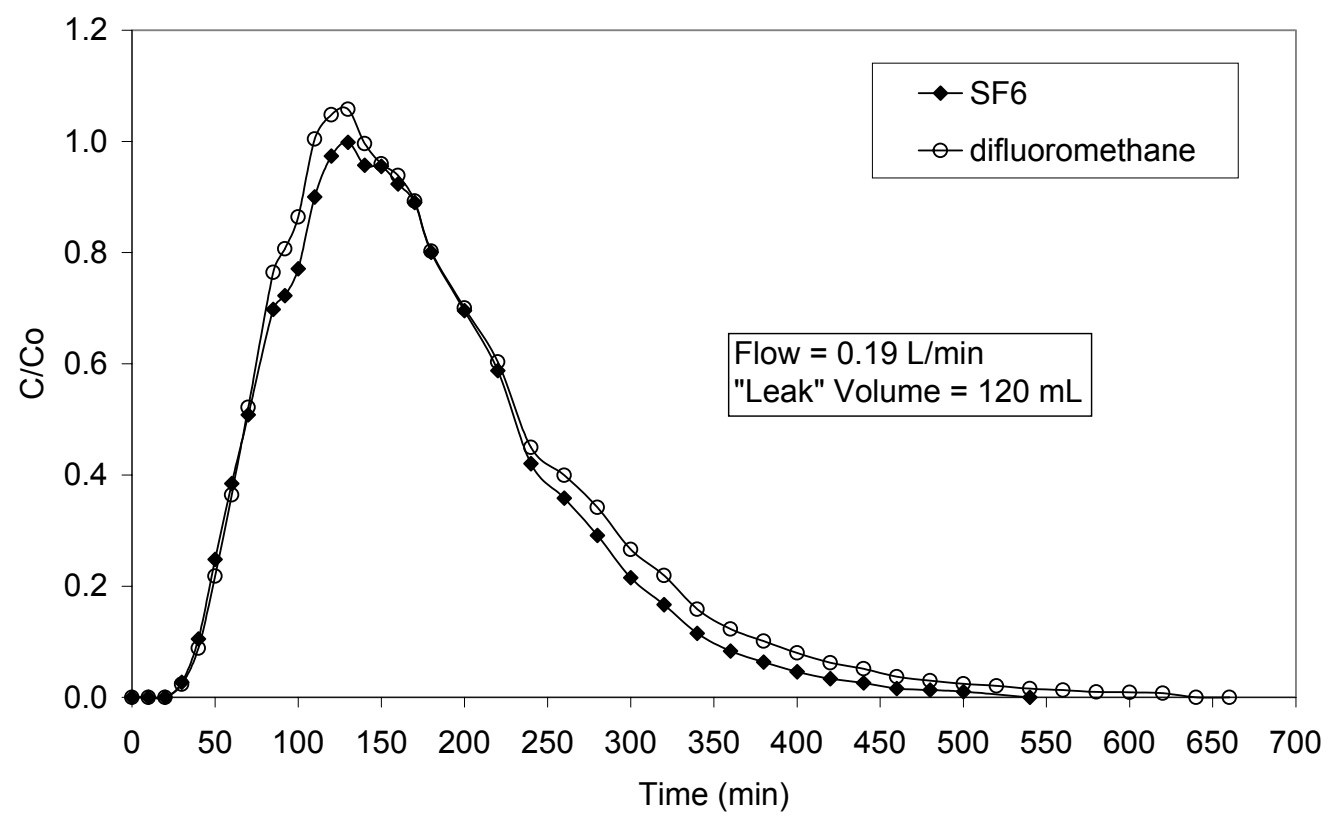

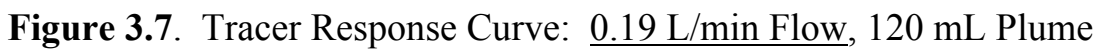




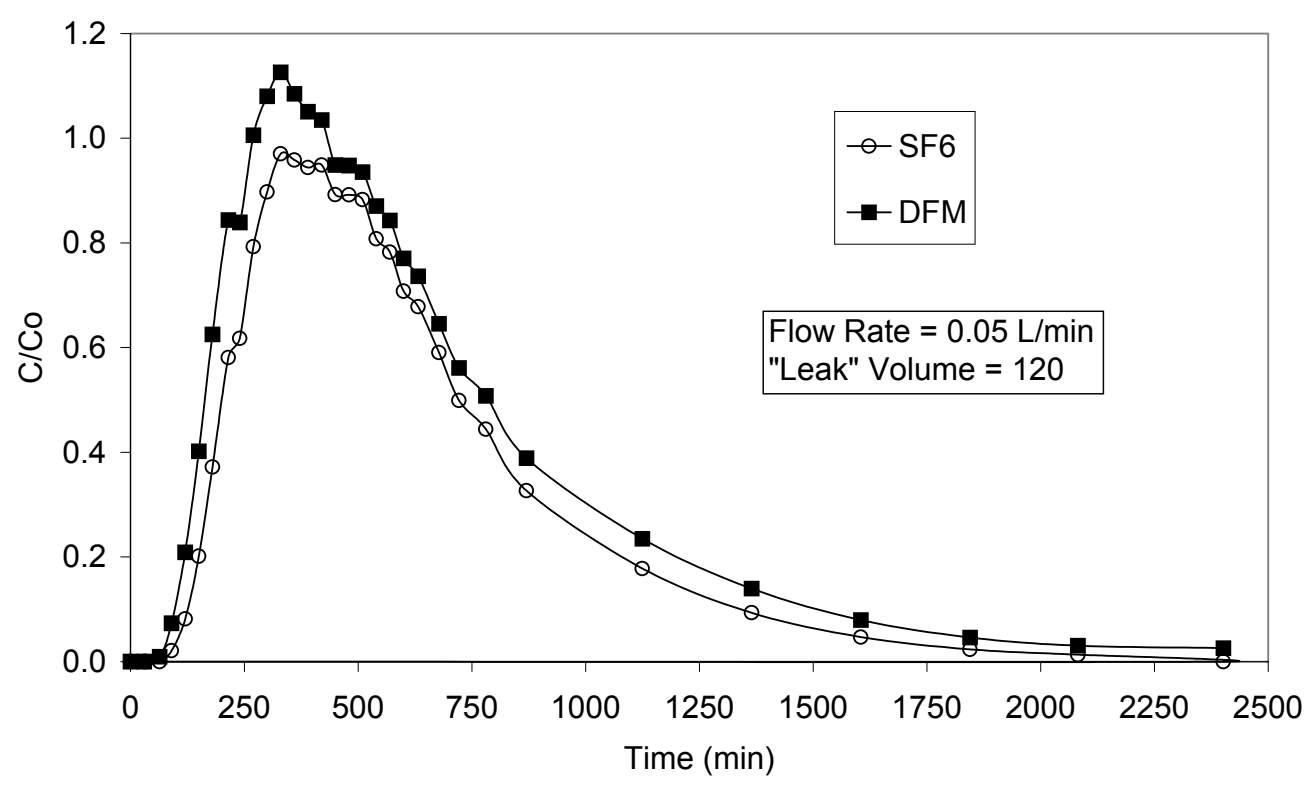

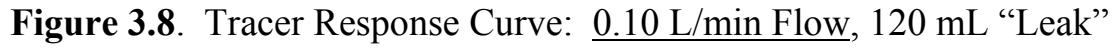

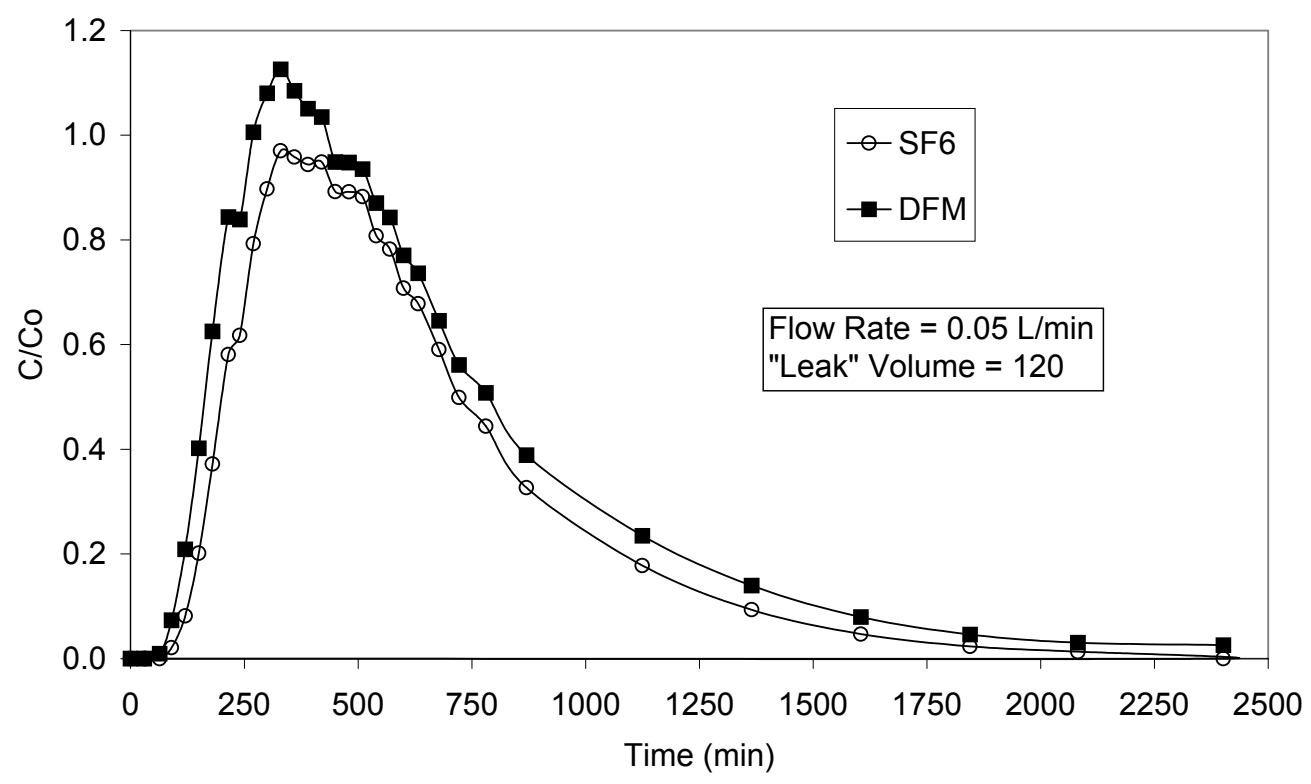

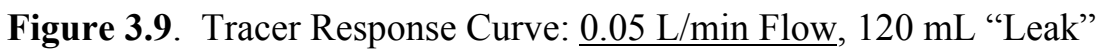


Table 3.1. Results of Experiment with Groundwater and $120 \mathrm{~mL}$ "Leak"

\begin{tabular}{||l|c|c||}
\hline \hline Flow & SF $_{\mathbf{6}}$ & Difluoromethane \\
\hline $\mathbf{0 . 1 9} \mathbf{~ m L} / \mathbf{m i n}$ & & \\
\hline Retardation Factor & 1.00 & 1.06 \\
\hline Mean Residence Time (min) & 173.7 & 184.5 \\
\hline $\mathbf{0 . 1 0} \mathbf{~ m L / m i n ~}$ & & \\
\hline Retardation Factor & 1.00 & 1.07 \\
\hline Mean Residence Time (min) & 309.6 & 331.6 \\
\hline $\mathbf{0 . 0 5}$ mL/min & & \\
\hline Retardation Factor & 1.00 & 1.07 \\
\hline Mean Residence Time (min) & 610.5 & 653.5 \\
\hline
\end{tabular}

The data in Figures 3.10 and 3.11 are the results of the first set of experiments with a "leak" of $200 \mathrm{~mL}$ and the "groundwater" simulation condition. Tracer tests were performed at two flow rates, $0.19 \mathrm{~L} / \mathrm{min}$ and $0.10 \mathrm{~L} / \mathrm{min}$. The results are summarized in Table 3.2 and show that, even with an additional $80 \mathrm{~mL}$ of "leak" in the flow cell (an increase of $67 \%$ liquid mass from the previous set of experiments), the tracer retardation factors remained consistent with the previous set of experiments. These experiments demonstrate the viability of the tracer behavior in actual flow conditions. However, later field testing showed that a larger difference in retardation factors of the conservative and partitioning tracers was required to quantify a "leak."

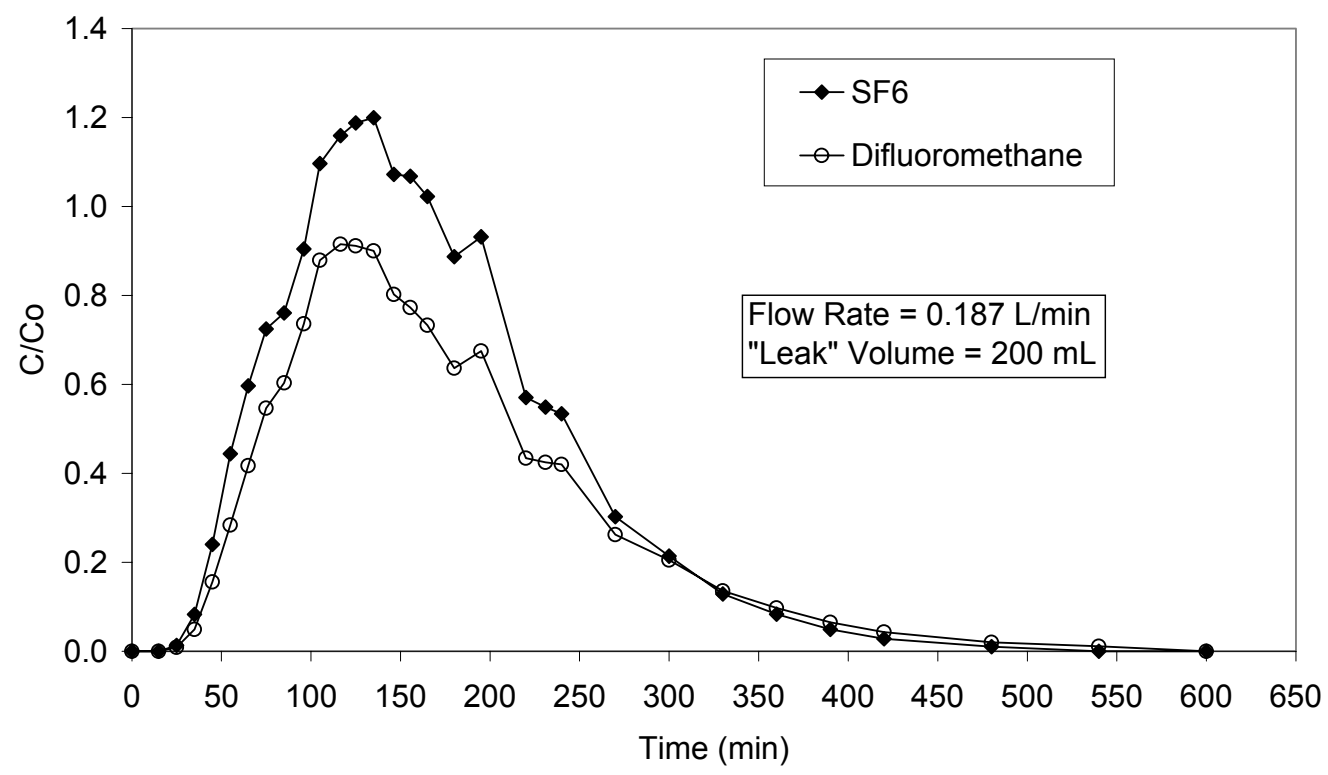






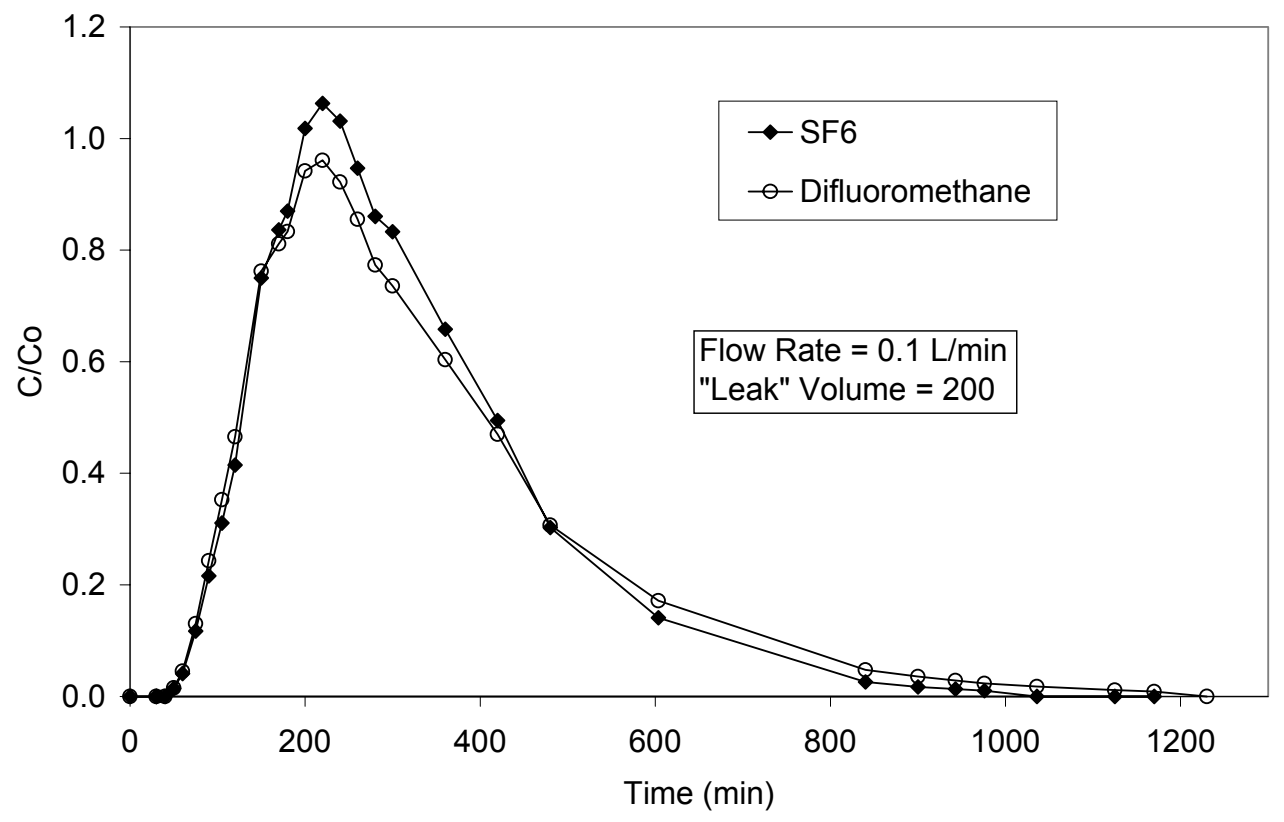

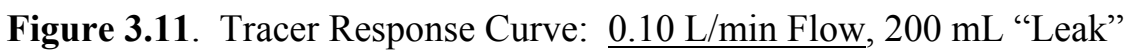

Table 3.2. Results of Experiment with Groundwater and $200 \mathrm{~mL}$ "Leak"

\begin{tabular}{||l|c|c||}
\hline Flow & $\mathbf{S F}_{\mathbf{6}}$ & Difluoromethane \\
\hline $\mathbf{0 . 1 9} \mathbf{~ m L} / \mathbf{m i n}$ & & \\
\hline Retardation Factor & 1.00 & 1.06 \\
\hline Mean Residence Time (min) & 173.7 & 184.5 \\
\hline $\mathbf{0 . 1 0} \mathbf{~ m L} / \mathbf{m i n}$ & & \\
\hline Retardation Factor & 1.00 & 1.07 \\
\hline Mean Residence Time (min) & 309.6 & 331.6 \\
\hline
\end{tabular}

\subsection{Tracer Behavior under Fast-Flow Conditions}

This experimental series was composed of eight individual experiments characterizing aqueous partitioning tracer behavior under varying flow conditions (see Appendix B for additional details). The first experiment verified aqueous partitioning coefficients for methane and difluoromethane at normal flow rates; the subsequent seven experiments investigated tracer partitioning behavior under faster flow rates than previously used in vadose-zone partitioning tracer method tests. The primary purpose of these experiments was to establish the effect of fast tracer flow on partitioning behavior as it relates to equilibrium partitioning.

The first three experiments in this series (Experiments 2A, 2B, 2C) were carried out using a column dry-packed with F-35 grade Ottawa sand and brought to residual water saturation of 0.238 by flooding 
and air flow. Volumetric measurement of the pore volume gave $35.9 \mathrm{~cm}^{3}$; a mass-balance estimate gave a pore volume of $35.4 \mathrm{~cm}^{3}$. Tracer concentrations of $1000 \mathrm{ppm}$ methane and difluoromethane (in dry nitrogen carrier) were injected at flow rates of $0.20 \mathrm{~cm}^{3} / \mathrm{min}, 0.70 \mathrm{~cm}^{3} / \mathrm{min}$, and $2.3 \mathrm{~cm}^{3} / \mathrm{min}$.

The Damkohler number (the dimensionless ratio of interphase mass transfer to advection) was calculated for each of these experiments to determine whether local equilibrium was achieved. According to the theoretical predictions of Deeds et al. (1999), the error in the saturation estimates for large Damkohler numbers should be very small, which is consistent with observations that the measured water saturations agree well with the mass balance measurements performed on the columns.

The results show that, for the residence times used in these experiments, water saturations measured by the partitioning tracer method are not affected by rate-limited mass transfer, provided the Damkohler number is large. This means that although the subsurface air flow rate is fast, the partitioning tracer is not affected in terms of its partitioning behavior.

The final four experiments in this series used higher flow rates than in previous experiments to investigate the effect of smaller Damkohler numbers on water saturation measurements. These experiments were carried out using a GC column (5.08-cm inner diameter; 7.62-cm pack length) shorter than that used in the previous experiments and dry-packed with F-95-grade Ottawa sand (F-35 grade was used previously). The packed column was brought to a residual water saturation of 0.270 by flooding and air flow. Volumetric measurement of the pore volume gave $54.2 \mathrm{~cm}^{3}$; a mass-balance estimate gave a pore volume of $53.8 \mathrm{~cm}^{3}$. The apparatus used for tracer injection and analysis was the same as the first series of experiments (see Figure 3.2), with tracer slug sizes regulated by use of the $17.5-\mathrm{cm}^{3}$ injection loop. Tracer concentrations of $1000 \mathrm{ppm}$ methane and difluoromethane (in dry nitrogen carrier) were injected at a flow rates of $0.81 \mathrm{~cm}^{3} / \mathrm{min}, 1.24 \mathrm{~cm}^{3} / \mathrm{min}, 2.20 \mathrm{~cm}^{3} / \mathrm{min}$, and $3.83 \mathrm{~cm}^{3} / \mathrm{min}$.

The Damkohler numbers were lower than the previous series, with the lowest at 1.21 and a mean tracer residence time of $0.27 \mathrm{hr}(16.2 \mathrm{~min})$. Although the Damkohler numbers approached unity with very short residence times, the water saturation estimates from the tracers were accurate. These experiments agree with the conclusions of Deeds et al. (1999) that mass transfer effects at Damkohler numbers greater than unity do not impact the moment analysis, provided that the tracer elution curve can be sufficiently captured. This means the partitioning tracer method is valid for measuring water saturation in the vadose zone even with very fast air flow rates.

\subsection{Tracer Partitioning Characteristics in Saline Solutions}

At PNNL, 14 experiments were carried out to investigate the effect of saline solutions on partitioning behavior. Specifically, this testing was used to estimate changes in tracer partitioning coefficients in ionic (saline) solutions such as tank wastes and simulants to determine the effect on tracer elution curves.

The first experiment was used to verify tracer partitioning behavior. It also served as a trial for later experiments and to substantiate capabilities in tracer experimentation. The next 13 experiments characterized tracer partitioning behavior in ionic solutions (sodium thiosulfate and sodium nitrate). Further details for these experiments are presented in Appendix B. The presence of $36 \mathrm{wt} \%$ sodium thiosulfate (as used in the demonstrations at the Mock Tank Site) reduced the difluoromethane dynamic 
$\mathrm{K}$, which is the partitioning coefficient under advective flow conditions, from 1.72 to 0.26 and the chlorofluoromethane dynamic $\mathrm{K}$ from 4.27 to 0.54

Two sets of experiments were also carried out at UT-Austin characterizing tracer partitioning behavior into saline solutions. The partitioning coefficient for difluoromethane decreased from 1.7 to only 0.25 when $40 \mathrm{wt} \%$ sodium thiosulfate was added to the water. The decrease in dynamic partitioning coefficients substantially increases the minimum leak volume detectable by the partitioning tracer method. 


\subsection{Site Characterization and Setup}

This section describes the Mock Tank Site, characterization activities, and modifications and equipment set up for SAFE activities performed during the FY 2001 TLDD. Additional information can be found in the FY 2001 Field Demonstration Test Plan, which is included as Appendix A.

\subsection{Site Description}

The Mock Tank Site is located in the 200 East Area of the Hanford Site (see Figure 1.1), east of B-Plant and across $7^{\text {th }}$ Street from the Strontium Semi-Works. The site was constructed in 1994 for testing the electrical resistance tomography (ERT) technology. It features a Mock Tank Structure, which is a 50-ft-diameter, 11-ft-high circular steel wall seated on a 4- to 6-in. concrete footer, with a 1/8-in. floor tack-welded out of sheet steel to approximate the electrical characteristics of an SST bottom. Emplaced around the tank are 16 PVC-cased boreholes (Figure 4.1) for deploying ERT electrode arrays to evaluate electrically based leak detection technologies. The two 2500-gal tanks held water or leak simulants.

The Technology Development Area (TDA) is directly east of the Mock Tank Structure. It was used for development and testing of SAFE activities prior to the TLDD (Figure 4.2). The SAFE technology demonstration took place at the Mock Tank Structure concurrently with the five geophysical method demonstrations. An infiltration gallery (IG) was constructed in the southeast corner of the TDA for a leak migration time-to-depth experiment.

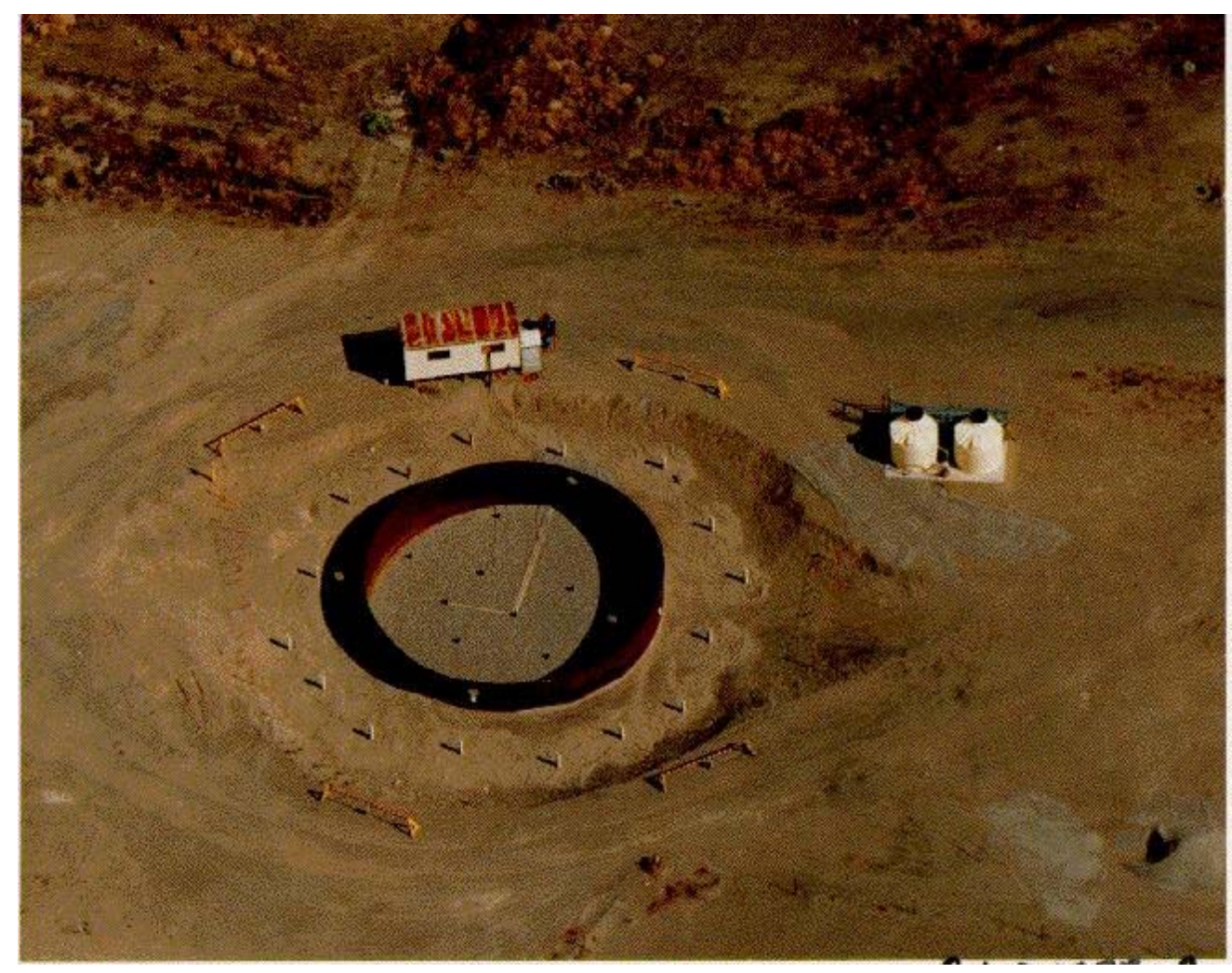

Figure 4.1. Original Mock Tank Site Constructed in 1994 


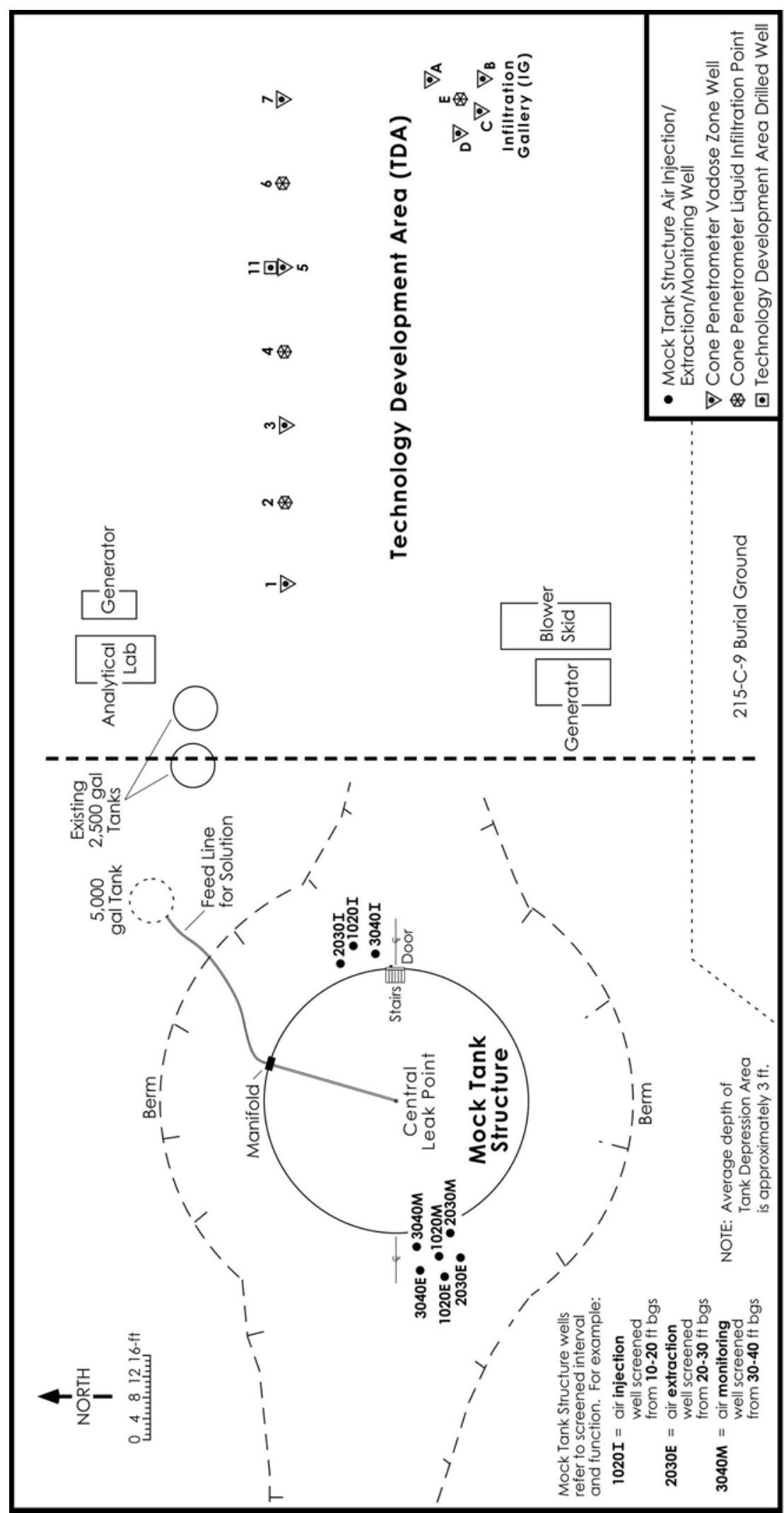






\subsection{Site Characterization}

This section briefly describes the site hydrogeology and details characterization activities carried out at the Mock Tank Site. A generalized cross-section showing the Mock Tank Structure and associated wells is provided in Figure 4.3.

\subsubsection{Site Hydrogeology}

Surficial sediments at the Mock Tank Site consist of a thin veneer of dune sand approximately $3 \mathrm{ft}$ thick; fluvial sand and gravel (Hanford and Ringold formations) extend from approximately $3 \mathrm{ft}$ to over $400 \mathrm{ft}$ below ground surface (bgs), down to the Columbia River basalt flows. Thin lenses of silt, clay, or calcareous silt occur at approximately 40 and $164 \mathrm{ft} \mathrm{bgs}$. The water table occurs at approximately $290 \mathrm{ft}$ bgs, with the base of the unconfined aquifer at approximately $400 \mathrm{ft}$ bgs at the basalt-sediment contact.

\subsubsection{Grain-Size Distribution and Hydraulic/Pneumatic Conductivity}

Grain-size distribution analyses were performed on 28 samples collected from a cone penetrometer (CPT) borehole south of Mock Tank Structure. Sampling occurred at 1-ft intervals from 7 to $35 \mathrm{ft}$ bgs. Three predominant textural groups (sandy gravel, silty sand, and sand) were identified from the analyses based on percentages of sample in four standard sieve sizes. The first group, at 27 to $28 \mathrm{ft}$ bgs, is a gravel-rich sand or sandy gravel. The second group is represented by three samples ( 8 to 9,25 to 26 , and 34 to $35 \mathrm{ft}$ bgs) and is a silty sand with fine sand, silt, and clay and trace amounts of gravel. The remaining 24 samples form the third group and basically comprise sand with very minor amounts of gravel, silt, and clay. Hydraulic conductivities were estimated for these groups by comparing them with sieve analyses and hydraulic conductivity values from nearby wells (Khaleel and Freeman 1995). The resultant values are shown in Table 4.1. Pneumatic conductivity values were then calculated based on the hydraulic conductivities. Additional details about these analyses are found in Appendix C.

Table 4.1. Textural Groups and Corresponding Hydraulic and Pneumatic Conductivities

\begin{tabular}{|l|c|c||}
\hline Group & $\begin{array}{c}\text { Hydraulic Conductivity } \\
(\mathbf{c m} / \mathbf{s})\end{array}$ & $\begin{array}{c}\text { Pneumatic Conductivity } \\
(\mathbf{c m} / \mathbf{s})\end{array}$ \\
\hline Sandy gravel & $1.8 \times 10^{-5}$ & $2.0 \times 10^{-6}$ \\
\hline Silty sand & $2.8 \times 10^{-4}$ & $3.1 \times 10^{-5}$ \\
\hline Sand & $8.7 \times 10^{-4}$ & $9.6 \times 10^{-5}$ \\
\hline
\end{tabular}

\subsubsection{Background Soil-Moisture Measurements}

Soil-sample analysis and CPT resistivity data collected from both the TDA and the Mock Tank Structure were correlated with neutron logging tool data from the IG and from CPT boreholes 8 and 9 (adjacent to the Mock Tank Structure) to characterize site-wide soil-water saturation. An overall water saturation value of $0.16(\mathrm{vol} / \mathrm{vol})$ was obtained from this analysis that agrees in general with other Hanford water saturation values. The soil moisture profile indicates silt layers at approximately 3.5 and $34 \mathrm{ft}$ bgs as suggested by a higher soil moisture content in these zones (Figure 4.4). 









Figure 4.4. Soil-Water Saturation from Neutron Log, Gravimetric, and Volumetric Correlation

\subsubsection{Sodium Thiosulfate Infiltration Test}

A time-to-depth liquid infiltration test using $36 \mathrm{wt} \%$ sodium thiosulfate solution was initiated July 16 , 2001 in the IG (see Figure 4.2). The purpose of this test was to gain an understanding of saline solution transport behavior in the vadose zone. The results from this test provided soil moisture characterization and stratification information for determining final placement of the SAFE CPT wells and for geosystem modeling and simulations for the partitioning tracer tests. Of the 434 gal of sodium thiosulfate solution that was prepared, 400 gal were injected. The additional solution was prepared to account for the 30 -gal heel of the solution storage tank. Injection of solution into well E began on July 16, 2001 at 12:03 pm with a flow rate of $25 \mathrm{gph}$. It was necessary to reduce the flow rate during the first few hours because the soil would not absorb the solution at the higher flow rate. The injection flow rate stabilized at $11.8 \mathrm{gph}$ and was maintained for the balance of the injection. Injection was completed at 5:30 pm, July 17, 2001, for a total of 400 gal injected into the subsurface.

Neutron probe readings were taken during the solution injection and at least daily thereafter to determine how quickly the fluid moved through the soil and at what depth changes in moisture occurred. To convert the readings from the neutron probe into useable moisture content numbers, it was necessary to use the site-specific relationship between the normalized neutron probe data and the volumetric moisture data obtained from the CPT during installation of IG wells.

The IG wells were logged for more than two weeks post-injection. In well $\mathrm{C}$, a small increase in moisture volume appeared in the 5 - to 25 -ft interval within 24 hours post-injection, with the largest increases at 8,13 , and $21 \mathrm{ft}$. In the next 24 hours, the moisture continued to travel downward, with further increases in the 10- to 20 -ft interval. Over the course of the two weeks, the largest volume increases were noted in the 10- to 20 -ft interval (Figure 4.5). In well A, moisture volume increased from 7 to $39 \mathrm{ft}$ bgs approximately 98 hours post-injection (on July 20, 2001). The bulk of the moisture change occurred between 33 and $39 \mathrm{ft}$ bgs (Figure 4.6). 


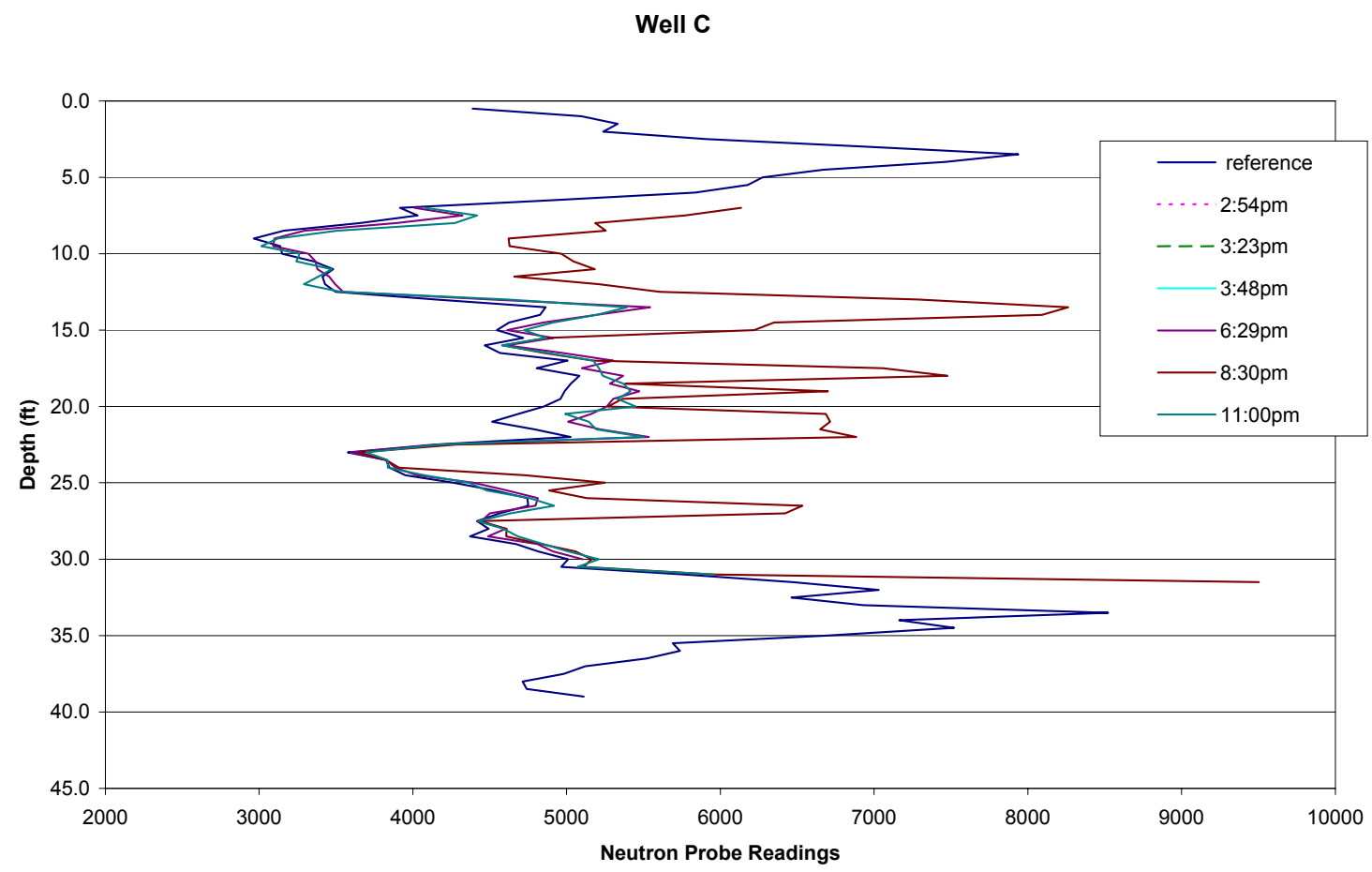

Figure 4.5. Soil Moisture Volume Changes in IG Well C

Well A

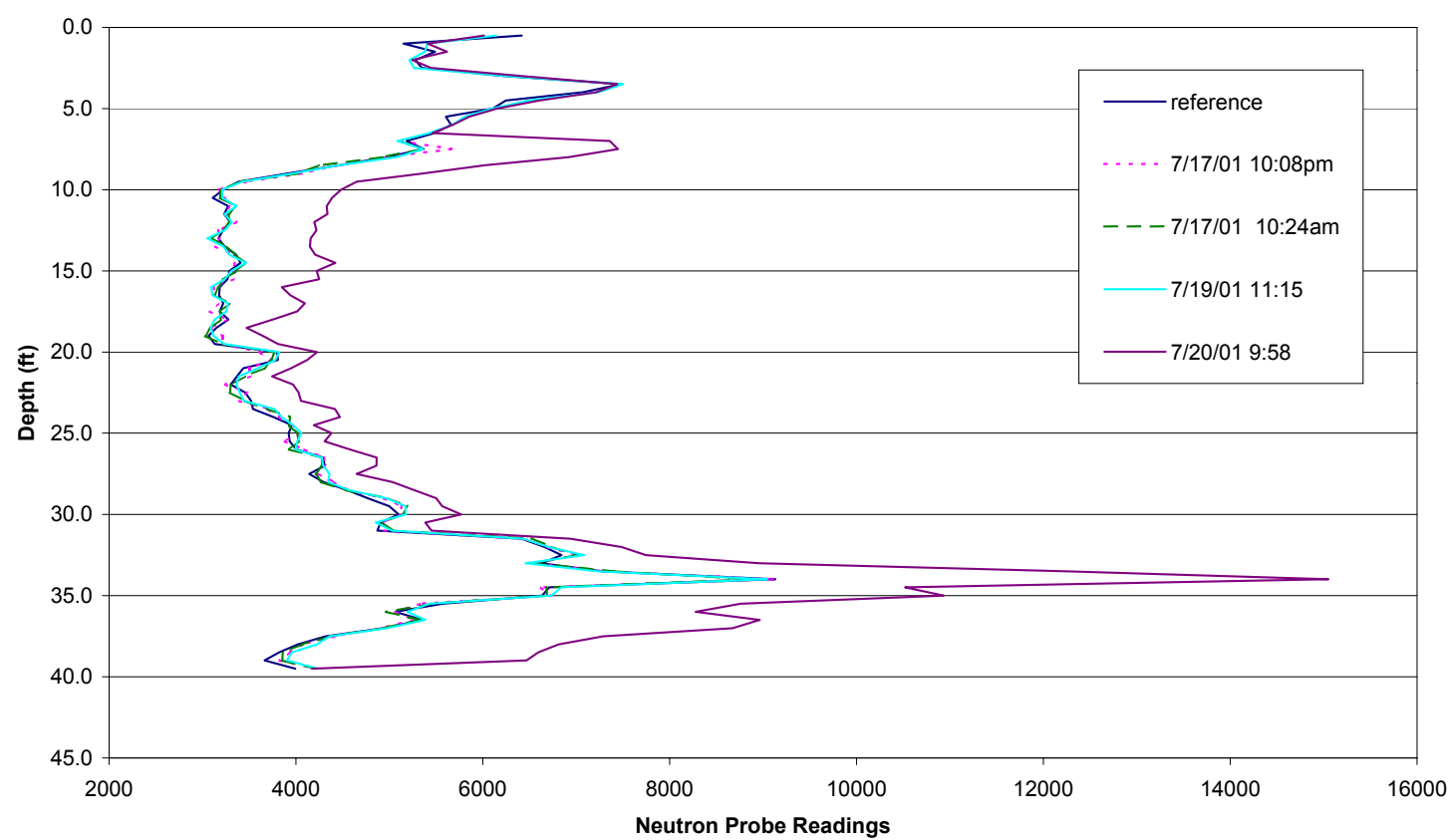

Figure 4.6. Soil Moisture Volume Changes in IG Well A 
The results of the infiltration experiment show that a portion of the injected fluid remains in relatively shallow strata (10- to 20-ft interval), while the remainder travels rapidly downward and laterally along permeable layers. This means that much of the simulated tank leakage (totaling 4000 gal) migrated rapidly out of the shallow layers directly under the Mock Tank Structure and passed through the lower levels of the zones of interrogation for all the technologies tested at the site.

\subsection{Modifications to Technology Development Area}

To facilitate testing, 12 2-in.-diameter boreholes were emplaced by CPT within the TDA, with three additional 2-in.-diameter CPT boreholes emplaced around the Mock Tank Structure for characterization purposes. A linear array of seven CPT boreholes forms the nucleus of the TDA; four of these boreholes were completed with PVC casings to $35 \mathrm{ft}$ bgs and screened intervals from 25 to $35 \mathrm{ft}$; three boreholes were completed to $8 \mathrm{ft}$ bgs as liquid injection points with screened intervals from 5 to $8 \mathrm{ft}$ bgs (see Figure 4.2). As mentioned previously, the IG was built in the southeast corner of the TDA. Here, four CPT boreholes were completed to a depth of approximately $40 \mathrm{ft}$ bgs (with unscreened PVC casings) around a central liquid injection point completed to $8 \mathrm{ft} \mathrm{bgs}$ with a screened interval from 5 to $8 \mathrm{ft}$ bgs. An additional 4-in.-diameter borehole (well 11 in Figure 4.2) was drilled in the TDA for pneumatic conductivity testing.

\subsection{Modifications to Mock Tank Structure}

Nine PVC-cased boreholes were completed to depths of up to $40 \mathrm{ft}$ around the Mock Tank Structure. These boreholes form a wellfield consisting of three triangular arrays (injection, monitoring, and extraction) with each array including three boreholes with 10-ft screened intervals (10 to $20 \mathrm{ft}, 20$ to $30 \mathrm{ft}$, and 30 to $40 \mathrm{ft}$ ) (see Figure 4.2). These wells are numbered according to their screened interval and function (2030I is an injection well screened from 20 to $30 \mathrm{ft} \mathrm{bgs).} \mathrm{Each} \mathrm{well} \mathrm{in} \mathrm{the} \mathrm{injection} \mathrm{array} \mathrm{is}$ aligned through the tank centerpoint with the monitoring and extraction well-array members with the same screened interval on the opposite side of the tank. All injection, monitoring, and extraction wells were used throughout the SAFE technology demonstrations.

\subsection{Instrumentation and Equipment}

Key air flow and analytical equipment used during the course of FY 2001 SAFE field activities are briefly summarized in this section.

\subsubsection{Air Flow Equipment}

Four high-capacity electric blowers powered by diesel generators were used to create the subsurface air flowfields at the Mock Tank Site. Generally they were used in pairs, one unit for injection and the other for extraction. The first unit consisted of skid-mounted, regenerative models with maximum flows of 345 and 184 SCFM and maximum pressures of 7.4 and 12.8 in. Hg, respectively. The second set, also regenerative blowers, had maximum flows of 405 and 350 SCFM and maximum pressures of 7.7 and 10.2 in. Hg, respectively. This set was used for backup at the TDA and then to boost flow capacity when activities moved from the TDA to the Mock Tank Structure. All of the blower motors were wired with 
circuit breakers to the generators. The injection blowers were fitted with air filters to prevent dust and debris injection. Water knockouts were installed on the extraction blowers to keep them from injecting excess water (the subsurface was at or near $100 \% \mathrm{RH}$ ).

\subsubsection{Analytical Equipment}

Two field GCs, connected to laptop computers for analysis, were used to sample the various tracer gases used for the SAFE activities at the TDA and the Mock Tank Structure. These instruments were used to 1) monitor tracers as they were being injected into the flowfield, 2) measure extracted in-tank tracers, and 3) measure tracers present at the extraction points of the flowfield during the partitioning tracer tests. The first GC was an MTI model P200 with a thermal conductivity detector. It was used in conjunction with the MTI EZChrom computer analysis program. The second GC was a Buck Scientific model 610 with an FID. The PeakSimple ${ }^{\circledR}$ data analysis program was used with this GC.

A multiple-depth-interval/multiple-well-array sampling protocol was devised for activities at the Mock Tank Structure. For this, an electronic sampling valve (VICI 16-position rotary valve) controlled by a laptop computer was used to feed samples into the GCs in a controlled cycle covering all of the extraction and monitoring wells. 


\subsection{Field Activities and Results}

This section describes the SAFE field activities and results from the FY 2001 TLDD. Table 5.1 shows an abbreviated field activity timeline. The field demonstration test plan for these activities is included as Appendix A. A detailed chronology can be found in Appendix F. These activities encompass leak detection, monitoring, and mitigation at the Mock Tank Site.

Table 5.1. Timeline of FY 2001 SAFE Activities

\begin{tabular}{||l|c|c|c||}
\hline $\begin{array}{c}\text { Date } \\
\text { (begin-end/yr) }\end{array}$ & Activity & $\begin{array}{c}\text { LDMM } \\
\text { Objective }\end{array}$ & Location \\
\hline $7 / 237 / 24 / 01$ & $\begin{array}{c}\text { Conservative Interwell } \\
\text { Tracer Test (CITT) }\end{array}$ & Baseline & $\begin{array}{c}\text { Technology Development } \\
\text { Area (TDA) }\end{array}$ \\
\hline $7 / 26-7 / 29 / 01$ & $\begin{array}{c}\text { Baseline Partitioning } \\
\text { Interwell Tracer Test } \\
\text { (PITT) }\end{array}$ & Monitoring & TDA \\
\hline $7 / 29-7 / 30 / 01$ & $\begin{array}{c}\text { In-Tank Tracer Test } \\
\text { (ITTT) }\end{array}$ & Detection & TDA \\
\hline $8 / 7-8 / 8 / 01$ & $\begin{array}{c}\text { Baseline PITT } \\
\text { (PITT-1) }\end{array}$ & Monitoring/detection & Mock Tank Structure \\
\hline $8 / 9-8 / 13 / 01$ & ITTT-1 & Detection & Mock Tank Structure \\
\hline $8 / 12-8 / 16 / 01$ & PITT-2 & Monitoring/detection & Mock Tank Structure \\
\hline $8 / 14-8 / 16 / 01$ & ITTT-2 & Detection & Mock Tank Structure \\
\hline $8 / 16-8 / 17 / 01$ & ITTT-3 & Detection & Mock Tank Structure \\
\hline $8 / 17-8 / 20 / 01$ & PITT-3 & Monitoring/detection & Mock Tank Structure \\
\hline $8 / 21-8 / 23 / 01$ & ITTT-4 & Detection & Mock Tank Structure \\
\hline $8 / 23-8 / 27 / 01$ & PITT-4 & Monitoring/detection & Mock Tank Structure \\
\hline $8 / 28-8 / 30 / 01$ & PITT-5 & Monitoring/detection & Mock Tank Structure \\
\hline $9 / 5-9 / 21 / 01$ & Soil Desiccation Test & Mitigation & Mock Tank Structure \\
\hline
\end{tabular}

TLDD activities at the Mock Tank Structure were organized around four scheduled injections of a leak simulant solution ( $36 \mathrm{wt} \%$ sodium thiosulfate) that was allowed to drain into the subsurface via an access point in the center of the tank. Injection dates and quantities are summarized below. At the time, injections \#1 and \#3 were blind.

- Injection 1, August 8 to 12, 1122 gal injected, 1122 gal accumulated.

- Injection 2A, August 13 to 15, 468 gal injected, 1590 gal accumulated.

- Injection 2B, August 15 to 16, 465 gal injected, 2055 gal accumulated.

- Injection 3, August 19 to 20,360 gal injected, 2415 gal accumulated.

- Injection 4, August 20 to 22, 1080 gal injected, 3495 gal accumulated.

Following injection 4, an additional 505 gal were injected, taking the accumulated total up to 4000 gal, after the formal TLDD. This allowed various leak detection technologies to gather additional data. Concurrent with this final injection, a variation on the partitioning tracer method was performed. This test was labeled PITT-6 and is briefly discussed in Appendix D. 
Five in-tank tracer tests (ITTTs) were performed. The first of these took place at the TDA and used nitrous oxide $\left(\mathrm{N}_{2} \mathrm{O}\right)$ as the tracer. Three-hundred-fifty gallons of water were sparged with $\mathrm{N}_{2} \mathrm{O}$ and injected into the subsurface. Three ITTTs were then carried out at the Mock Tank Structure during injection activities using a tracer suite of difluoromethane and pentafluoroethane. A final ITTT at the Mock Tank Structure used chlorodifluoromethane as a tracer and employed a highly sensitive tracer sampling and analysis technique (Tedlar bag and gas chromatography/mass spectrometry [GC/MS]) for improved leak detection. The ITTTs targeted the leak detection objective of the LDMM task matrix.

Flowfield disturbance leak detection methods were tested using conservative tracer elution curves from the four injections at the Mock Tank Structure. Although these used the tracer elution curves from the PITTs, the method was applied as a leak detection technology in the form of a series of baseline conservative interwell tracer tests (CITTs) to gauge flowfield characteristics. This was followed by leak detection CITTs to observe changes in tracer elution caused by decreased pneumatic conductivity from tank leaks.

One baseline PITT was carried out at the TDA, then a compressed demonstration schedule precluded any further activity before injection activities began at the Mock Tank Structure. One baseline PITT was carried out at the Mock Tank Structure, but a power fluctuation induced a computer failure, and the result was a gap in the data. Thus, no baseline data were obtained. Four subsequent PITTs were conducted. The PITTs targeted the leak detection and monitoring objectives of the LDMM task matrix.

Soil desiccation for leak mitigation was tested following the conclusion of PITT activities. The SAFE flowfield was used to extract moisture from the soil column underneath the tank, demonstrating the potential of the method to mitigate less-than-catastrophic leaks. This method could also be used to dry the subsurface before retrieval activities began, reducing the matric potential and achieving a "pre-leak mitigation" condition that would limit leak transport and improve the sensitivity of all ex situ leak detection technologies by reducing background soil moisture.

All injection, monitoring, and extraction wells were used throughout the course of testing.

\subsection{In-Tank Tracers}

\subsubsection{Nitrous Oxide In-Tank Tracer Test at Technology Development Area}

The initial demonstration of the ITTT leak detection methodology was performed at the TDA using a nitrous oxide tracer. Prior to injection, 350 gallons of water were sparged with nitrous oxide for seven hours to reach near-saturated conditions. The water was injected $8 \mathrm{ft}$ bgs in CPT-2 midway between the air injection and extraction wells (see Figure 4.2). These injection and extraction wells have screened intervals of 25 to $35 \mathrm{ft}$ bgs.

Figure 5.1 is a concentration-versus-time plot. The nitrous oxide exhibits an extremely large response once the liquid reaches the upper portion of the well screens. The 43-hour delay from the start of the "leak" injection is mostly related to 1) the infiltration time for the water to reach the zone of interrogation and 2) significantly shorter transport time for the tracer across the flowfield. This initial test 
Nitrous Oxide Concentration vs. Time



Figure 5.1. Nitrous Oxide ITTT at the TDA

demonstrated that a major fraction of the dissolved tracer was transported with the liquid over a significant distance through the vadose zone until stripped by the advective flowfield. The success of this test demonstrates the viability of the in-tank tracer concept.

\subsubsection{Difluoromethane/Pentafluoroethane In-Tank Tracer Test at Mock Tank Structure}

The use of a gas phase in-tank tracer creates the possibility of alternative exit routes from the tank other than liquid leaks during saltcake removal. Some tanks are known to have leak pathways associated with the dome and risers. Using soluble (difluoromethane) and insoluble (pentafluoroethane) tracers can be an effective way to distinguish headspace venting from liquid-leak components, assuming the tank is passively vented. Tracers associated with leaks occurring above the interstitial liquid level (ILL) would be detected equally well with both tracers, whereas only the strongly soluble tracer would be detected in a true liquid-phase leak. To demonstrate the viability of this method, the first ITTT at the Mock Tank Structure (ITTT-1) used a low-cost, commercially available refrigerant that was a 50-50 azeotropic mixture of difluoromethane and pentafluoroethane. Pentafluoroethane has very low water solubility.

Figure 5.2 shows the detection of tracer for injections 1,2A, and 2B. The first detection of tracer was observed 11 hours after injection 1 began, corresponding to leak detection after 135 gal of solution had entered the subsurface (Figure 5.2). The peak height was very small at that time (two to three times the method detection level [MDL]), although it persistently appeared only in upper-zone monitoring well $1020 \mathrm{M}$ (see Figure 4.2 for well location). A gas sample was collected in a Tedlar bag and analyzed by GC/MS to verify that it was indeed difluoromethane. This indicated a positive detection event in spite of the relatively marginal initial peak height. The significance of the early breakthrough of a very small amount of tracer is difficult to fully assess. Because the zone of interrogation was $17 \mathrm{ft}$ below the point of injection, liquid transport processes heavily dominated tracer arrival time. The first arrival of tracer thus 


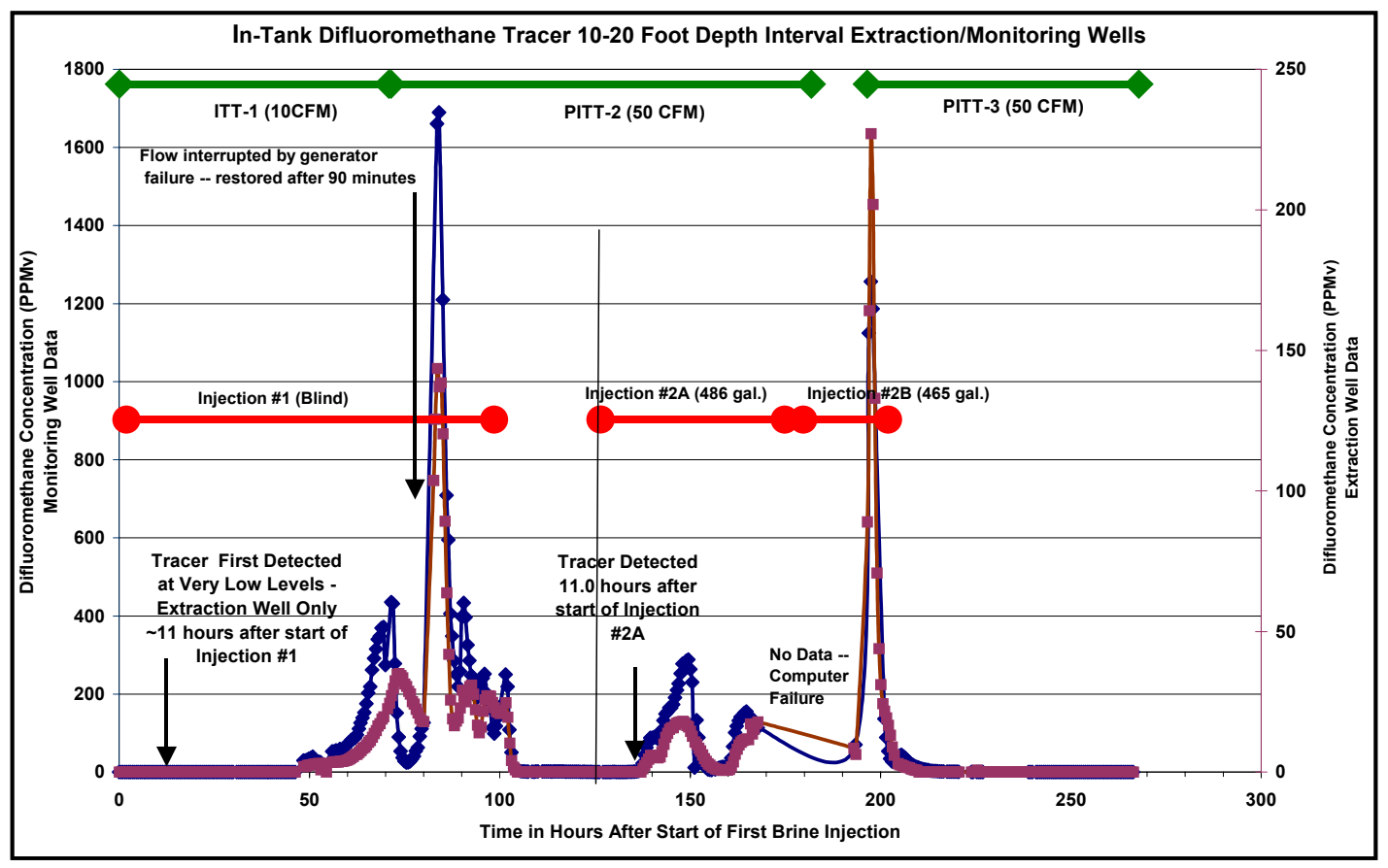

Figure 5.2. Mock Tank Structure ITTT-1, -2, -3

represents a minor intrusion by a small amount of liquid (fingering), while the main mass of liquid containing tracer appears to have spread laterally. The arrival times are not primarily associated with leak volume but with vertical migration rate. Vertical migration rates are influenced by several factors, including soil properties and ambient moisture content; however, liquid introduction rate and the volume introduced also affect migration rate. As such, the amount of liquid used in the test and the injection rates were partially incompatible with a direct measurement of detection sensitivity. To perform such a test properly would require injecting a smaller amount of liquid (10 to $100 \mathrm{gal}$ ) at a lower injection rate. Because conditions for the TLDD were intended for testing the less-sensitive partitioning tracer and geophysical methods, circumstances were not fully appropriate for evaluating an in-tank tracer. Ideally, the zone of advective flow interrogation would be much closer to the bottom of the tank to eliminate liquid transport delay and dilution effects. That was not practical at the Mock Tank Structure because of the proximity of the tank base to the surface, but would be desirable for tank farm deployment.

For ITTT-1, the main mass of tracer took more than 50 hours to appear at major concentrations (more than three orders of magnitude above the MDL). Additional ITTTs were performed during injections 2A and $2 \mathrm{~B}$. After injection $2 \mathrm{~A}$, tracer was again detected after 11 hours, corresponding to leak detection after 120 gal of solution had entered the subsurface; however, in this case, major concentrations of tracer were observed promptly, indicating that the primary liquid front was already present in the zone of interrogation from the previous injection. Pentafluoroethane was absent in all tests except for very minor amounts (consistent with the limited solubility of the compound) during the periods of maximum difluoromethane impact. Arrival at the zone of interrogation was considerably more rapid for injections after the first one, indicating a more rapid transport of the liquid in a pre-wetted zone in the formation. Similar effects were observed by the geophysical methods; however, these conditions (pre-wetting) do not accurately reflect the type of transport effects likely to occur during an actual low-volume, low-rate tank leak. It is important to be able to interrogate the region very close to the tank itself, including, if possible, that layer just 
below the tank bottom. This would be necessary to detect a leak reliably by any detection method. Both tests showed a moderately complex structure to the time-dependent pattern of tracer recovery with strong peaking behavior toward the latter phase of leak injection. The reason for that behavior is not well understood. It is likely to be related to the transport characteristics of the liquid and subsurface heterogeneities. Further experiments are needed to determine whether that behavior is typical or anomalous.

\subsubsection{Chlorodifluoromethane In-Tank Tracer Test at Mock Tank Structure}

The final Mock Tank Structure ITTT (performed during solution injection 4) used chlorodifluoromethane (CFC-22) as a tracer. CFC-22 is also available as an azeotropic mixture with pentafluoroethane; however, for this test, only the pure compound was used for simplicity. Unlike nitrous oxide and difluoromethane, chlorodifluoromethane (and pentafluoroethane) is amenable to collection and preconcentration using triple-sorbent tubes in-line that yield extremely high analytical sensitivity. Figure 5.3 shows the concentration as a function of time in the 10 - to 20 - $\mathrm{ft}$ extraction well.

The peak concentrations observed were much lower than previous tests due to an intentionally lower gas saturation factor and the larger dilution using the extraction well rather than the monitoring well. Chlorodifluoromethane is also somewhat less soluble than difluoromethane. In spite of those sensitivity reductions, the tracer was easily detected with the field GC under favorable conditions. Sensitivity enhancements of at least five orders of magnitude can be obtained easily using a laboratory-based GC/MS and triple-sorbent tubes for in-field automated sample collection and preconcentration (see Section 5.1.4 for more details). In the final ITTT, readily detectable levels of tracer occurred only 7.5 hours after solution sparging began (solution injection began before sparging), corresponding to leak detection after $150 \mathrm{gal}$ had entered the subsurface. In this case, arrival time and associated leak volume are primarily a function of injection rate and subsurface transport effects.

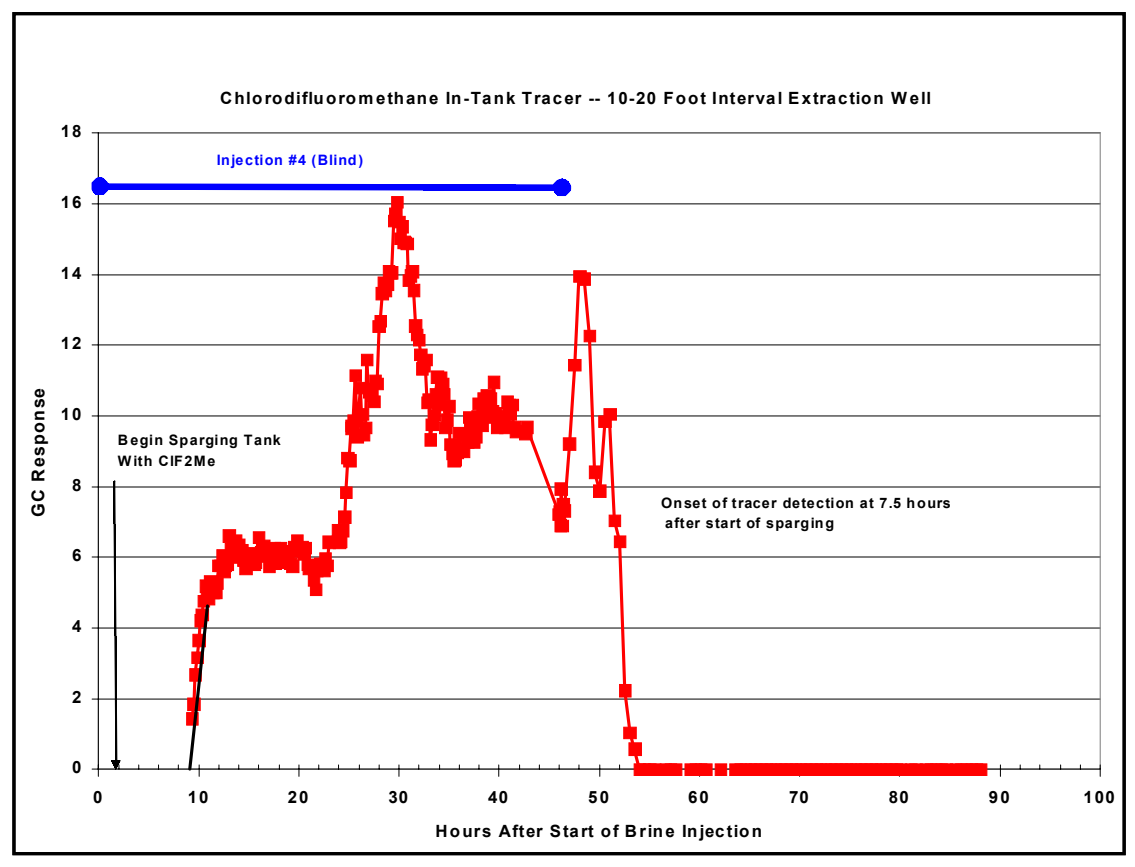

Figure 5.3. Mock Tank Structure ITTT-4 


\subsubsection{Extended In-Tank Tracer Studies}

Since the completion of field activities in FY 2001, additional laboratory work has been performed in FY 2002 to further develop the in-tank tracer concept. The FY 2002 work was supported by PNNL through internal Laboratory Directed Research and Development (LDRD) funding. Several tracers were tested in FY 2001, including nitrous oxide, difluoromethane, and chlorodifluoromethane. Nitrous oxide and difluoromethane performed very well as tracers, demonstrating that a dissolved gaseous tracer follows the liquid in the subsurface very effectively until removed by advective stripping; however, in those experiments, high tracer saturation was needed in the infiltrated brine because the analytical method used (field GC; $\mathrm{MDL}=1 \mathrm{ppmv}$ ) was not sensitive enough to detect small amounts of tracer that would be more representative of actual tank farm conditions.

The Mock Tank Structure was not an actual tank, and the tests performed in FY 2001 were not intended to duplicate true in-tank conditions for any of the methods tested. Realistically, a relatively low saturation level, ranging between 0.01 and $0.1 \%$, would be more appropriate for use in an actual tank provided greatly enhanced analytical detection methods are used to recover the lost sensitivity.

Neither nitrous oxide nor difluoromethane are amenable to ultra-high-sensitivity analysis. Chlorodifluoromethane was demonstrated in the last of the FY 2001 tests to have suitable characteristics for use as a tracer and also showed promise for ultra-sensitive detection. Chlorodifluoromethane is also very inexpensive. It has been used for years as a commercial refrigerant. The analytical method of choice providing maximum sensitivity for chlorodifluoromethane is a combination of sample collection on commercially available Supelco 300 triple sorbent traps and laboratory analysis by GC/MS. Sample collection can be performed by commercially available automated sampling equipment. Because relatively large air samples can be concentrated on the traps ( 1 to $10 \mathrm{~L}$ ) with the trace analyte burden (sans air) transferred in its entirety to the GC/MS separation column, very low detection limits are attainable. The basic methodology has been in routine use at PNNL for at least seven years for Hanford nuclear waste tank vapor headspace characterization and numerous other applications.

Laboratory experiments performed under PNNL internal funding in FY 2002 demonstrated that the analytical method was viable for attaining detection limits in the low part-per-trillion (pptv) range for chlorodifluoromethane (an improvement of five to six orders of magnitude over the field GC measurements) but was marginal with respect to sample breakthrough on the traps, requiring careful control of flow conditions and total sample volumes. Ambient air background concentrations were found to be in the range of 40 to $50 \mathrm{pptv}$ at several different locations, somewhat lower than but similar to the concentration reported in the open literature for that compound. The ambient air background results from several decades of use for industrial purposes. Chlorodifluoromethane appears to be viable as an in-tank tracer when used in amounts in the range of $0.1 \%$ in the tank headspace.

PNNL also investigated chlorofluoromethane as an in-tank tracer. Chlorofluoromethane is a more strongly partitioning tracer that was used in the PITT study in FY 2001. Thus it was unavailable for concurrent use as an in-tank tracer during those tests. Chlorofluoromethane has very favorable partitioning and analytical properties. It is more strongly bound on triple-sorbent traps than chlorodifluoromethane, minimizes the breakthrough problem, and has more favorable GC/MS characteristics. Its retention time keeps the compound well separated on the GC column from any other potentially interfering atmospheric components, and its mass spectrum is very distinctive, providing a very high 
degree of rejection for false positives. Individual GC/MS runs can be made in less than 10 minutes each and can be reduced easily to a very routine operation. The ambient air background of chlorofluoromethane was found to be less than $1 \mathrm{pptv}$. Although chlorofluoromethane is far more expensive than chlorodifluoromethane, its much greater sensitivity as a tracer means that less of the compound is needed. Chlorofluoromethane thus appears to be the tracer of choice for future consideration, although chlorodifluoromethane is also viable; its less desirable characteristics can be overcome by using a lot more of it.

Column experiments using both difluoromethane and chlorofluoromethane as partitioning tracers provide a basis to rescale the results of the FY 2001 field work as applied to tank farm deployment. Figure 5.4 shows the results of a series of partitioning experiments using sodium nitrate as simulated waste brine. The plot shows that chlorofluoromethane and difluoromethane behave in essentially identical fashion with respect to solubility as a function of sodium molarity. Even at saturated brine conditions, chlorofluoromethane still has rather high solubility. Similar though less detailed results were obtained both at PNNL and UT-Austin for the nearly saturated sodium thiosulfate solution used in the field-testing program. Based on these results, it is possible to reliably estimate the detection sensitivity for chlorofluoromethane as an in-tank tracer.

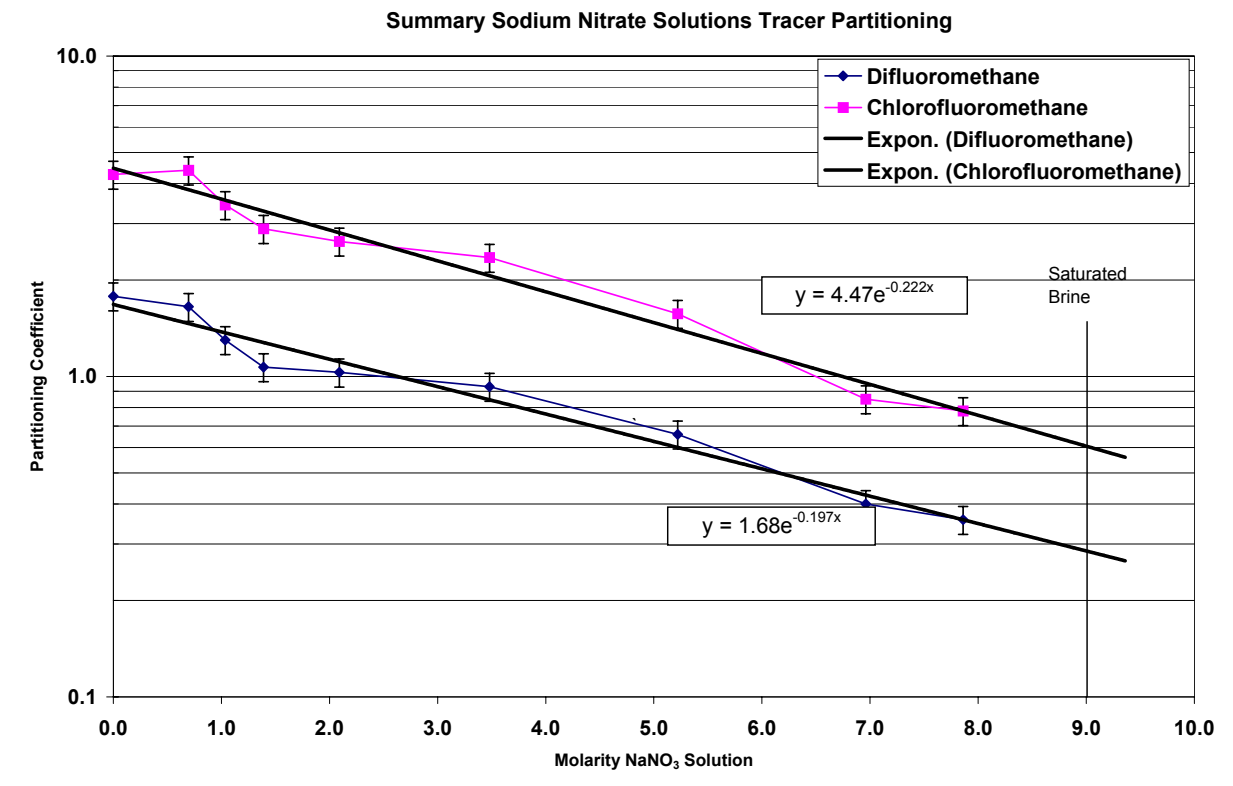

Figure 5.4. Partitioning Behavior of Difluoromethane and Chlorofluoromethane as a Function of Sodium Molarity

\subsubsection{Use of In-Tank Tracers for Tank Farm Deployment}

With difluoromethane used as the tracer on injections 2A and 2B at the Mock Tank Structure (see Figure 5.2), the measured concentration at the extraction well was $32 \mathrm{ppmv}$ averaged over the full period of liquid addition, for a combined 951-gallon leak. The difluoromethane tracer was fully saturated in the brine during a long sparging period and maintenance at that level with a blanket of $100 \%$ tracer gas above the liquid in the holding tank; however, because the tracer was only $50 \%$ difluoromethane (the balance 
was pentafluoroethane, a non-partitioning tracer), a factor of 2 must be used to scale the results to tank farm application. Chlorofluoromethane is 2.7 times as soluble as difluoromethane. For tank farm use, full saturation with chlorofluoromethane is not practical because of cost and safety considerations; therefore, a saturation factor of 0.0001 , which roughly corresponds to adding $1 \mathrm{~kg}$ of tracer to the headspace of a 1-million-gallon SST, was assumed. One kg of chlorofluoromethane tracer costs approximately $\$ 600$. For a 10-gal leak with a saturation factor of $0.01 \%$ (a factor of 0.0001 ) the expected average concentration in the air at the extraction well is $180 \mathrm{pptv}$. The best MDL attained so far for chlorofluoromethane using a combination of triple-sorbent tubes for automated in-field sample collection and laboratory analysis by GC/MS with ion selective monitoring is $<1 \mathrm{pptv}$. The MDL can easily be improved by a factor of 5 to 10 simply by collecting larger samples. At the $1 \mathrm{pptv}$ level there was no chlorofluoromethane found in ambient air. It is likely that the true ambient level is considerably lower because of the very limited industrial use for that compound.

At the tank farm scale, there is a 50\% longer flowpath for advective transport between air injection and air extraction wells; however, any additional dilution would be more than offset by a more optimal placement of wells. At the Mock Tank Structure, the flowfield was originally intended for a different purpose, and the simulated tank bottom was too close to the surface of the ground for optimal well placement. In this analysis the flowfield is assumed to consist of three injection and three extraction wells in an opposed geometry. That type of pattern should be attainable by perforating and packing existing dry wells in place. At Tank S-112, a suitable well layout exists that could be used. For tank farm deployment, the extraction interval would be much closer to the bottom of the tank than at the Mock Tank Structure; the extraction intervals would also be narrower ( $5 \mathrm{ft}$ instead of 10); and it is likely that the flow rate would be lower than was used for the FY 2001 ITTT studies.

Overall, a significant improvement in sensitivity is likely by optimizing the advective flowfield in that way. However, that has not been fully demonstrated, so no major enhancement is assumed here but to cancel out the $50 \%$ loss due to longer flowpath. Based on these assumptions and results from laboratory/ field studies, a leak of about 10 gal would have a detection sensitivity about 100 to 200 times higher than the ambient background and the MDL for chlorofluoromethane. The liquid detection sensitivity for brine thus computes numerically to much less than 1 gal; however, that small a number is essentially meaningless because such a tiny amount of liquid would not transport beyond the confines of the tank. A realistic detection limit taking transport into account is probably about 10 to 100 gal. A 100-gal leak would thus deposit enough tracer into the advective zone to produce a signal more than three orders of magnitude above the detection limit. This level of sensitivity provides a significant margin for sensitivity in the 100gal range even allowing for loss of tracer within the tank and incomplete equilibration with the liquid. This argument assumes that a $0.01 \%$ concentration of chlorofluoromethane can be maintained in the tank headspace, providing a reservoir to equilibrate with the dissolved brine in accordance with the measured partitioning coefficient for concentrated sodium nitrate solution.

A supplier has been identified who can immediately provide at least $50 \mathrm{~kg}$ of the chlorofluoromethane at a price of $\$ 30 \mathrm{~K}$ for the lot, which should be adequate to provide for replacement of tracer due to various loss processes during the full course of waste retrieval at S-112. For long-term use beyond S-112, supply of the chemical could be a problem that will need further investigation.

Active ventilation would render the use of a gaseous in-tank tracer far less practical than the passive ventilation typical of most SSTs. It appears unlikely that active ventilation would be employed during the 
S-112 retrieval because of the very low organic content of that tank combined with the costs for installation and operation of a ventilation system. Active ventilation represents a potential operational constraint for the in-tank tracers tested to date at PNNL. Active ventilation was used during the partial retrieval of waste from Tank C-106, a high temperature, high-organic-content tank, so at least some of the SSTs could be problematic from that standpoint. For tanks using active ventilation, in-tank tracer tests could still be performed during a shutdown of the blowers but not on a continuous basis.

Distribution of tracer into the tank remains an important operational consideration that must be worked out once the retrieval plans are finalized. Current plans for the Tank S-112 retrieval call for a kind of "inside-out" salt dissolution approach in which water is added to the waste through a series of steerable high-pressure nozzles located in the center of the saltcake above the salt well. Liquid will be added and removed at the same rate (initially $10 \mathrm{gpm}$ ). The most straightforward way to add the tracer would be in the influent water. In that case, tracer would be associated primarily with the portion of the tank waste directly involved in the dissolution operation. The ability to mix liquid added during the dissolution process with interstitial liquid throughout the tank is not well understood. Thus, the amount of tracer present at a leak site where the sidewall meets the bottom of a tank might be limited. For the intank tracer method to be used with certainty, the mechanism for tracer distribution throughout the waste must be further studied.

One further issue is false positives. Because the tracer to be used (chlorofluoromethane or chlorodifluoromethane) is a gas, alternative exit paths from the tank above the liquid level could, in principle, produce a false positive not related to an actual brine leak. That is of particular concern if the top of the extraction interval is designed to be at or slightly above the bottom of the tank. In several of the FY 2001 tests, a second, non-partitioning tracer, pentafluoroethane, was also used as a tracer for the gaseous pathway. That concept appears to be very sound based on the field results with a 50-50 difluoromethane/ pentafluoroethane mixture. Appearance of chlorofluoromethane without a corresponding amount of pentafluoroethane associated with the headspace would indicate a liquid phase rather than a gas phase leak. That, in fact, was what was observed in the field tests at the Mock Tank Structure, in which only the partitioning tracer was found in the extracted air. If both tracers were detected in the stoichiometric ratio added to the tank, that would be clear evidence that an alternative pathway such as a riser or piping leak was the source. If such a pathway proved dominant, it would reduce the effectiveness of the tracers for leak detection of brine, and some repositioning of the extraction well intervals would be needed. Pentafluoroethane is a modern-generation, ozone-friendly refrigerant that has seen limited use. It is very inexpensive, and its analytical properties are very similar to those of chlorofluoromethane. The ambient air background of pentafluoroethane was also found in PNNL's recent lab studies to be less than the analytical limit of $1 \mathrm{pptv}$, so it has been demonstrated to be fully compatible with the intended use.

\subsection{Flowfield Disturbance}

Flowfield disturbance leak detection methodology was evaluated using the conservative tracer elution curves from the five PITTs conducted at the Mock Tank Structure. These tests employed methane as a conservative tracer. For future work, this method would be implemented in a stand-alone mode as a series of baseline CITTs to establish flowfield norms and leak detection CITTs to monitor changes in tracer elution behavior. 
It is a clearly understood principle that reduction of pneumatic conductivity will occur with the introduction of liquid into the vadose zone. This means the air flowfield will be changed because air cannot flow through liquid-filled pores. Thus, the air and tracers flowing through the subsurface will develop new pathways, resulting in changes to the tracer effluent behavior. Those changes should be detectable through changes in the pattern of conservative tracer recovery alone; however, no predictive modeling or experimental verification of the effect had been performed prior to testing.

Introduction of dense brine into the sediment column should have two important effects. Initially, the pore space is filled near the zone of intrusion, resulting in a sharp decrease in pneumatic conductivity. That effect should be transient as the brine plume disperses through both horizontal and vertical transport. However, the high ionic strength of the brine solution will also cause a more lasting effect associated with swelling of clay minerals. Porosity decreases (resulting in reduced pneumatic conductivity) associated with the latter effect should be cumulative even after loss of saturation through vertical transport. Decreased pneumatic conductivity in at least part of the region interrogated by the advective flowfield has the effect of changing the gas flow behavior, resulting in a shift in the first temporal moment and variability in the shape of the conservative tracer elution curves.

An examination of Figures 5.5 and 5.6 (ignoring baseline curves) shows the decrease in arrival time of successive conservative tracer injections as leak volume increases for the moment of the first peak. A general early time shift in concentration peaks (also visible in Figure 5.7), consistent with previously modeled conservative tracer behavior, is also evident. The baseline test had a large data gap (shown as a straight pink line from 0.3 to 0.5 days) caused by computer failure coincident with the concentration

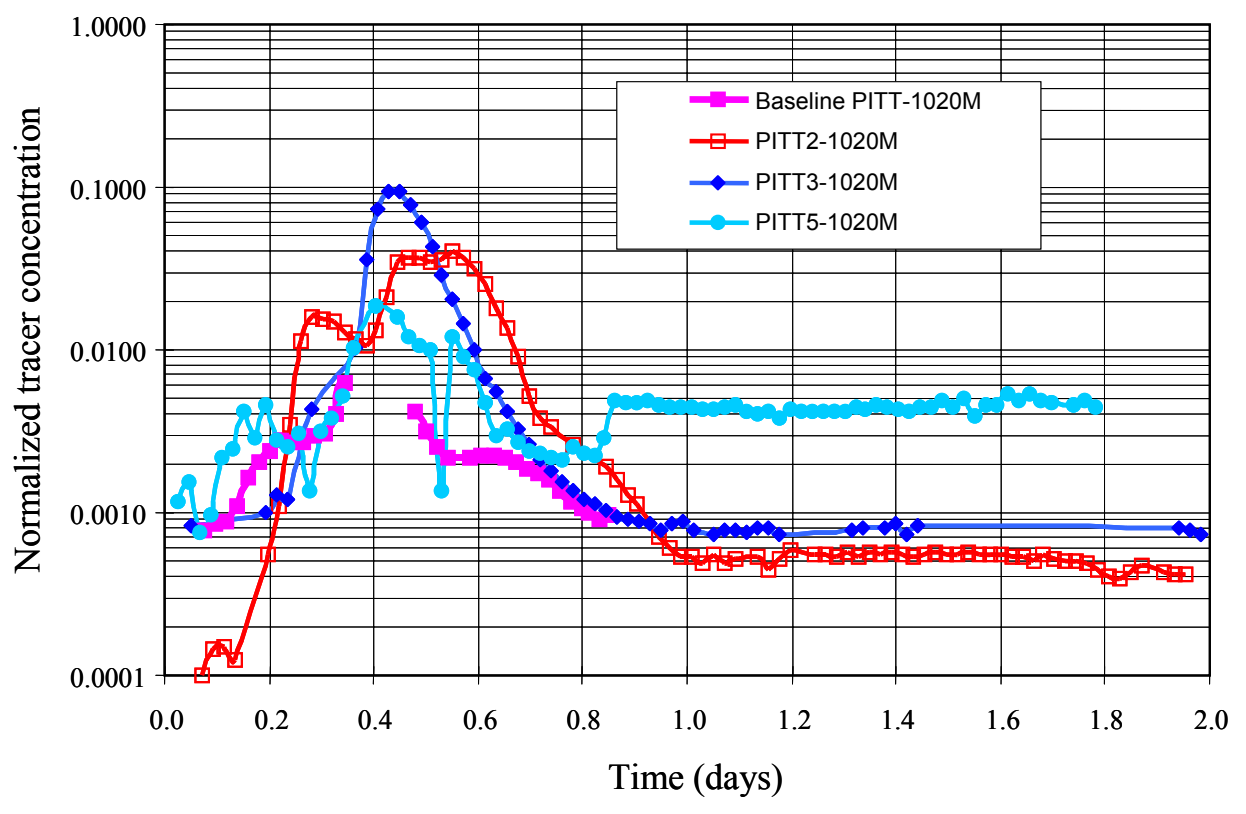

Figure 5.5. Methane Response at Monitoring Well 1020M 


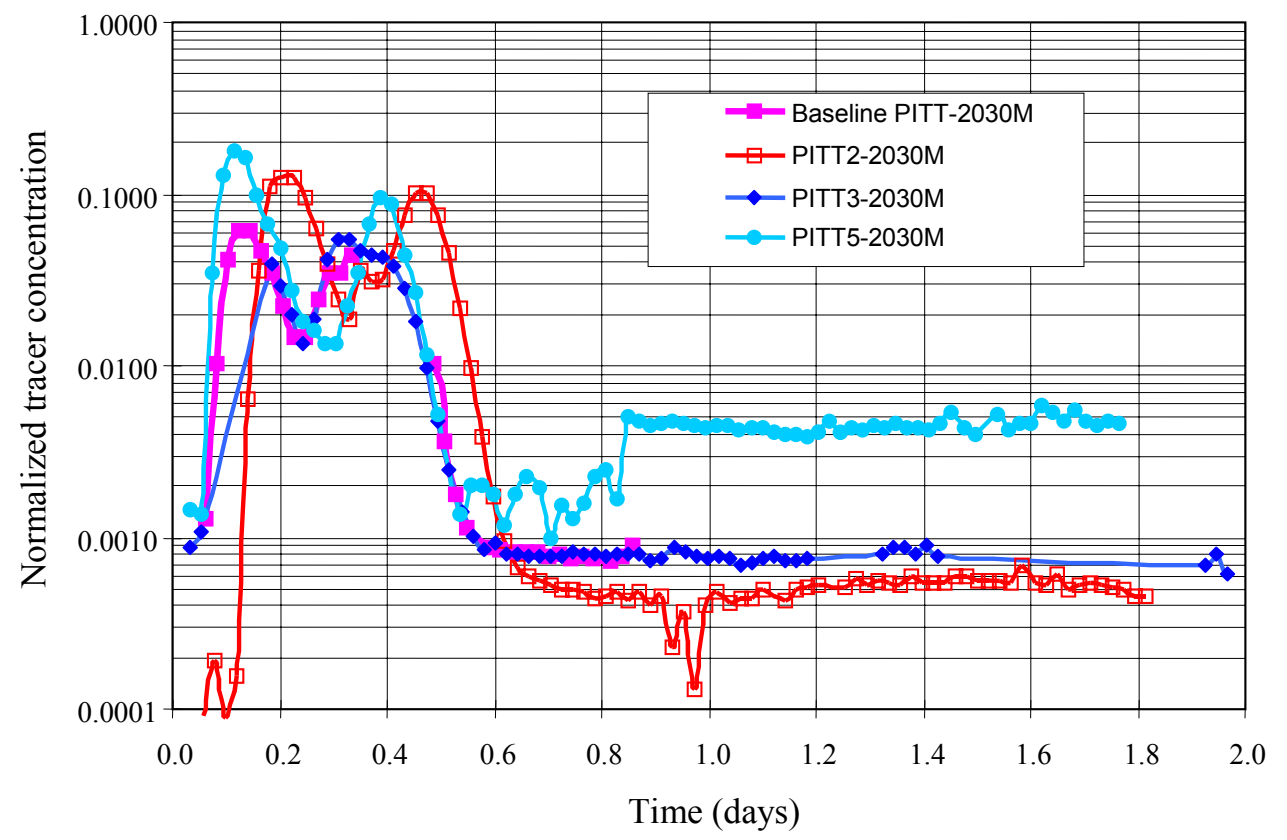

Figure 5.6. Methane Response at Monitoring Well 2030M

maximum for the conservative tracer, rendering it unusable. Limitations imposed by the test schedule prevented any additional baseline studies. Lack of baseline data is a serious limitation for flowfield data interpretation.

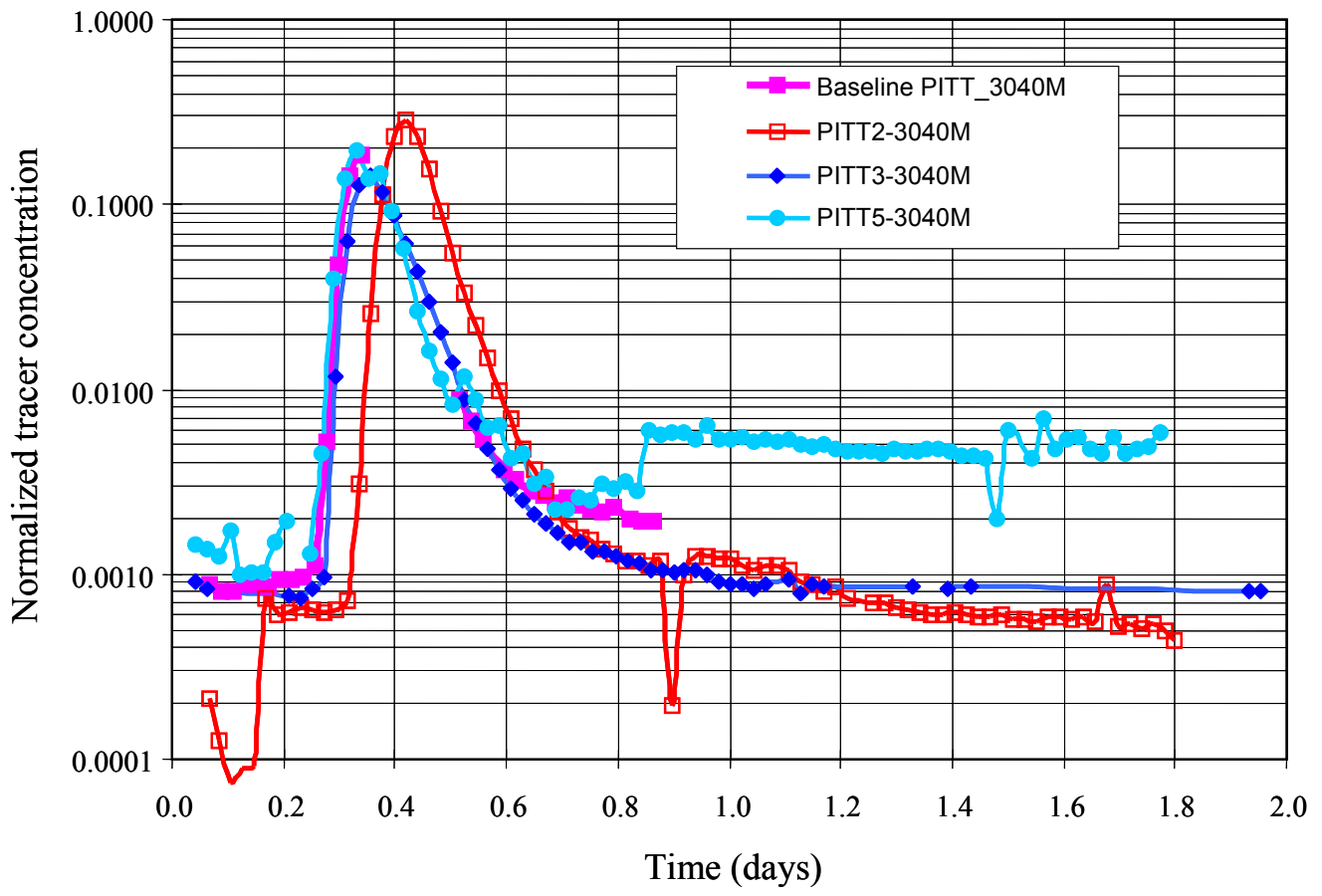

Figure 5.7. Methane Response at Monitoring Well 3040M 
The results shown in Table 5.2 indicate that the first moments of the conservative tracer decreased progressively for PITT-2, PITT-3, and PITT-5. These data clearly indicate that the pneumatic conductivity has been reduced due to brine infiltration by the mechanisms discussed above. The largest relative change was observed in the middle zone (20 to $30 \mathrm{ft} \mathrm{bgs}$ ), which is consistent with results of the geophysical surveys that showed transport of the brine to that zone over a prolonged period of time. Fluctuations in the flow rate, pressures, and tracer slug size of different PITTs could also contribute to changes in first moment of the tracer responses, though these changes would be very slight compared with the significant tracer elution variances that were observed. Additional studies that include several repeat baseline runs and tighter flow control are needed to fully assess this method.

Table 5.2. Summary of the First Moments of the Conservative Tracer Response Curves

\begin{tabular}{||c|c|c|c|}
\hline \multirow{2}{*}{ PITT ID } & \multicolumn{3}{|c|}{ First Moment (days) } \\
\cline { 2 - 4 } & Well 1020M & Well 2030M & Well 3040M \\
\hline PITT-2 & 0.49 & 0.31 & 0.42 \\
\hline PITT-3 & 0.46 & 0.29 & 0.38 \\
\hline PITT-5 & 0.45 & 0.23 & 0.36 \\
\hline
\end{tabular}

\subsection{Partitioning Tracer Method}

A baseline PITT (no solution injected into subsurface) was carried out at the TDA using the same wells as the TDA CITT (see Table 5.1) (CPT-1, -3). A tracer suite of methane, chlorofluoromethane, difluoromethane, and pentafluoroethane was employed. Data were collected for approximately 74 hours. First-moment analysis of elution curves resulted in a baseline soil moisture of 0.05 .

A series of five partitioning tracer tests were then performed at the Mock Tank Structure. All five tests used methane as the conservative tracer and chlorofluoromethane as the partitioning tracer. Prior to the first injection, a baseline PITT was performed. The other four partitioning tracer tests were performed during and after the liquid injections.

All of the partitioning tracer tests were complicated by several electrical power disruptions and subsequent instability of site blowers and field GCs. The tests were further complicated by the low partitioning behavior of chlorofluoromethane in brine. The conservative tracer elution curves did, however, allow for initial investigation of using flowfield disturbance for leak detection, as noted in Section 5.2.

Tracer data from extraction well 2030E were analyzed for PITT-2, -3, and -5 using the method of first temporal moments. The baseline test was not considered to be useable for this analysis because of the large data gap noted above. Figures 5.8 through 5.10 illustrate the normalized tracer elution data with the corresponding fitted curves.

Analysis of the data set shows that the values of estimated average water saturations and volumes continue to change as a function of the integration time interval. As such, no meaningful interpretation of the data can be made. Normally, these data can be used to determine a shift of the moments (or centroids) of the elution curves, and these changes in moments, coupled with the partitioning coefficients of the tracers, allow the increased volume of soil moisture to be calculated. 


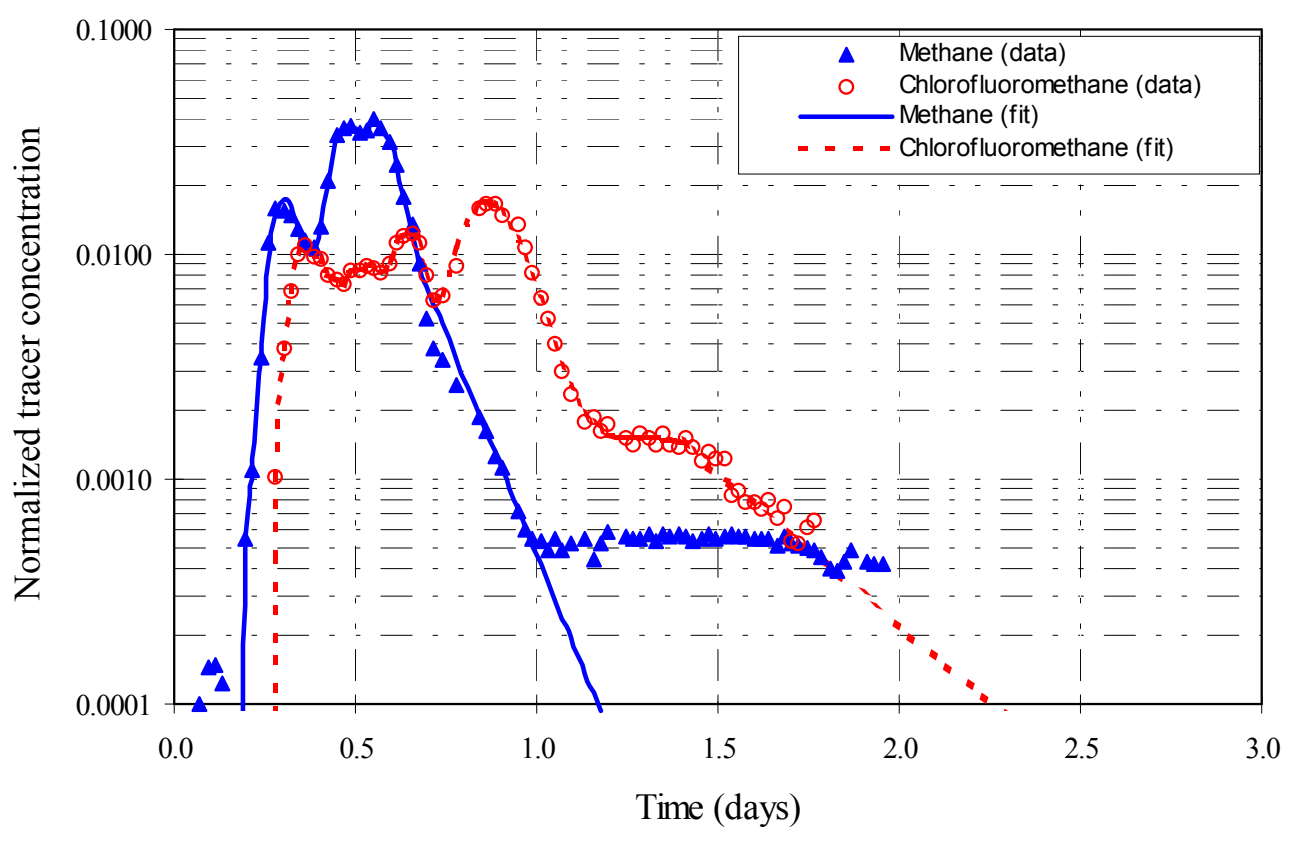

Figure 5.8. PITT-2 Tracer Response Curve

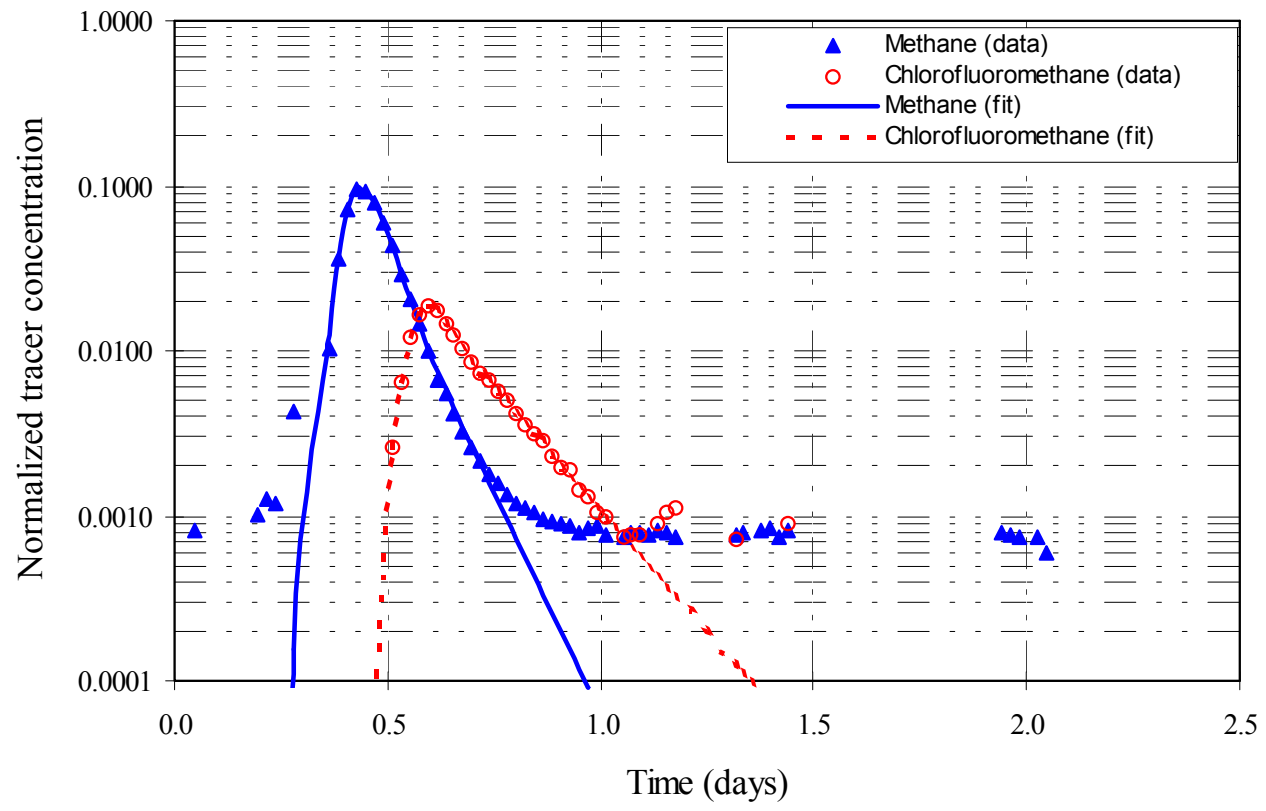

Figure 5.9. PITT-3 Tracer Response Curve 




Figure 5.10. PITT-5 Tracer Response Curve

The swept pore volumes of the monitoring wells were calculated using the area under the conservative tracer elution curve as a function of time. They are presented below:

- Upper Interval (10 to $20 \mathrm{ft}$ bgs $)=39,700+/-500 \mathrm{ft}^{3}$

- Middle Interval (20 to $30 \mathrm{ft}$ bgs $)=24,300+/-300 \mathrm{ft}^{3}$

- Lower Interval (30 to $40 \mathrm{ft}$ bgs $)=34,000+/-500 \mathrm{ft}^{3}$

The swept pore volumes show the volume of soil interrogated at each interval and directly relate to the tracer residence time. The volumes reflect the site scenario in that the upper and lower intervals were less bounded than the middle interval. None of the intervals were bounded on the sides because no injection/extraction wells were used on the sides. The use of additional wells would reduce the swept pore volumes, decreasing the tracer residence time (and thus the amount of tracer "tailing"), resulting in the potential for more frequent tracer injections and better tracer data. Additional wells will be used in future testing and any tank farm deployment.

In summary, analyses performed on both the monitoring and extraction well data for water saturation proved inconclusive for the following reasons:

1. Low partitioning coefficient with the brine solution-Laboratory experiments performed on the concentrated sodium thiosulfate solutions in parallel with the field work demonstrated that a large decrease in the partitioning coefficient was associated with the high-ionic-strength brines for the classes of compounds currently available for field use. This large decrease caused a corresponding reduction in the sensitivity of the partitioning tracer method to changes in moisture associated with brine relative to background soil moisture. This does not invalidate 
the partitioning tracer method for tank leak detection; however, it does point out the need for further development to identify and test tracers with adequate partitioning behavior in brine solutions.

2. The tracers were not pneumatically contained - The design of this simple wellfield did not provide full pneumatic containment of the tracer flowfield, creating slowly swept stream tubes and resulting in very long tracer tailing effects. An actual tank farm deployment would use several well couples and multiple flow directions to provide the pneumatic containment. The containment was further complicated by the succession of leaks bringing down additional liquid on top of the tailing tracers.

3. Potential influence from the residual tracer mass from previous PITTs-Some of the tracer mass flowing in the slowly swept stream tubes was captured in subsequent PITTs, resulting in complications with data analysis.

4. Lack of early time data for the tracer response curves-Because the tracers moved through the subsurface at different rates due to variations in pneumatic conductivity, some of the tracer mass arrived at the extraction wells very quickly (within a few minutes). However, only one GC was available to sample all six extraction locations (with each interval measured only once every 30 minutes), so early time data were not completely gathered. Based on these results, future tests would include additional analytical equipment.

5. Insufficient detection limits and high background concentrations of methane-The tail portions of the tracer response curves were not properly characterized due to either a lack of lower detection limits or high background concentrations, resulting in tracer response curves that could not be properly extrapolated.

To overcome these limitations, further development work is necessary. A first step is to identify and test tracers with adequate partitioning behavior in a brine solution, though the best tracers may prove to be those that react with the brine solution, changing into new compounds or reducing in concentration. Such reactive tracers can be used and analyzed like partitioning tracers.

\subsection{Soil Desiccation Tests}

Soil desiccation may be used as a leak mitigation technique by reducing the matric potential of the soils underneath a tank. During the tests conducted at the Mock Tank Structure, air was injected on one side of the tank at the three depth intervals and extracted on the other side, resulting in advective air flow underneath much of the tank. This advective air flow removed soil moisture from beneath the tank in the form of water vapor. Following the tracer testing, the subsurface air flow rate under the tank was increased and continued for a two-week period to further demonstrate the potential for subsurface drying. An $\mathrm{RH}$ of $100 \%$ was measured in the effluent of each extraction well over the entire period.

During the TLDD, a total of 3,849,900 $\mathrm{ft}^{3}$ of air was extracted from below the Mock Tank Structure, resulting in the removal of 376 gal of water. During the extended desiccation test of two weeks, a total of $6,912,000 \mathrm{ft}^{3}$ of air was extracted from below the Mock Tank Structure, resulting in the removal of 632 gal of water. Thus, a total of 1,008 gal of water was removed from beneath the Mock Tank Structure by the SAFE activities. 


\subsection{Implications for SAFE Technology Usage in SST Retrieval, Closure, and Post-Closure}

Four SAFE technologies were demonstrated in the FY 2001 TLDD at the Mock Tank Site. They include in-tank tracers, flowfield disturbance, the partitioning tracer method, and soil desiccation. Three of these (in-tank tracers, flowfield disturbance, soil desiccation) were deemed successful. Key results and implications for future work are discussed below. Additionally, the suite of potential SAFE technologies applicable to LDMM grew significantly as this project evolved. These complementary technologies would utilize the same subsurface advective flow system and infrastructure as the other four; however, they are less mature and will require significantly more development before field-testing or deployment.

\subsection{In-Tank Tracers}

The in-tank tracer technology was first demonstrated at the TDA. It verified that dissolved tracer can be transported with the liquid and then stripped by the advective flowfield. At the Mock Tank Structure, the in-tank tracer technology detected the first leak after $135 \mathrm{gal}$ had entered the subsurface, the second leak after 120 gal entered the subsurface, and the final leak after 150 gal entered the subsurface.

These results are noteworthy considering the technology was not fully developed, multiple tracers were used, and analysis was performed primarily with a field GC (detection was confirmed using a laboratory GC/MS). Since the completion of field testing, additional laboratory testing and process refinement has resulted in a robust technology that has excellent potential for SST leak detection. One specific advance is based on the use of triple-sorbent sampling tubes with GC/MS analysis. This approach reduces the limit of tracer detection down by about five to six orders of magnitude (to low ppt range). This improvement in collection and analysis should allow the detection of 10- to 100-gal leaks from SSTs with a very high degree of confidence.

Recently, concerns have arisen over the ability to ensure tracer distribution throughout tank waste during retrieval and that this may limit the usefulness of this technology. While this may be valid for detecting historical leaks, it is unlikely to be a problem for retrieval operations. As envisioned, the intank tracer would be sparged into the influent water used for saltcake dissolution. Any leak resulting from retrieval activity could contain both the leaked solution and the in-tank tracer, which, in turn, would be detected in the subsurface flowfield. However, this requires further study under conditions that more closely mimic a tank farm deployment.

It is also important to note that the in-tank tracer technology is the only technology at this time that can clearly discern that a detected leak is from the tank being retrieved and not moisture coming from another tank or ancillary piping. The in-tank tracer method has been developed and demonstrated to a maturity level where it is ready for stepped-up testing that more closely represents a tank farm deployment. 


\subsection{Flowfield Disturbance}

The second leak detection technology successfully demonstrated during FY 2001 field testing was flowfield disturbance. This technology attributes changes in the elution behavior of a conservative tracer to changes in the pneumatic conductivity in the subsurface. The pneumatic conductivity changes arise from water filling the pore spaces between soil particles or swelling of the clay minerals. In the testing at the Mock Tank Structure, the conservative tracer elution behavior was clearly altered by the leaks introduced into the subsurface, resulting in the unmistakable detection of a leak. This technique should work equally well for leak detection under an SST because any liquid leaking from the tank would affect the adjacent soils in a similar manner.

\subsection{Partitioning Tracer Method}

Laboratory tests were performed in the spring and early summer of 2001 to identify appropriate partitioning tracers and their corresponding partitioning coefficients. However, scheduling issues necessitated that these tests be completed in parallel with the field tests at the Mock Tank Structure. As a result, the TDA was quickly designed and installed. Selected field tests were attempted to gain some understanding of partitioning tracer behavior in the subsurface and to gather data as input for designing the wellfield at the Mock Tank Structure. As soon as this wellfield was installed, a PITT was attempted to establish a baseline for the impending leaks. An electrical power failure interrupted the test, and a baseline measurement was never achieved. Failure to obtain this baseline severely hampered any meaningful interpretation of the partitioning tracer data for leak detection and monitoring.

Four tests were completed using the partitioning tracer technology. Evaluation of the results from three of the tests using monitoring wells to minimize the swept volume indicated a progressive trend toward increasing water saturations in the upper two intervals (10 to $20 \mathrm{ft}$ bgs and 20 to $30 \mathrm{ft}$ bgs). This was particularly important for the last period tested, which was likely to have the largest accumulated volume of liquid present at that time. Unfortunately, a detailed error analysis of the available data indicated that there was inadequate precision from which to draw firm conclusions. The problem was further exacerbated by the lack of a usable baseline PITT measurement.

To overcome these limitations, further development work is necessary. A first step is to identify and test tracers with adequate partitioning behavior in a brine solution, though the best tracers may prove to be those that react with the brine solution, changing into new compounds or reducing in concentration. Such reactive tracers can be used and analyzed like partitioning tracers.

\subsection{Soil Desiccation}

Soil desiccation was also successfully demonstrated at the Mock Tank Structure in FY 2001. More than 1,000 gal of moisture were removed from the subsurface by the air flow extraction activities. Soil desiccation could be readily implemented under an SST as well. Over the course of several weeks to months, a zone of reduced soil moisture would be created, which would act to hold up any leak. Additionally, soil desiccation could be used as a mitigation tool by removing moisture from an existing water leak, reducing its matric potential and preventing downward migration of contaminants. 


\subsection{Complementary Technologies}

In addition to the four primary SAFE technologies tested in FY 2001, other advective flowfield technologies have been identified that could be developed and used for LDMM and subsurface characterization. One of these technologies, ISGR, had a successful field deployment for chromium reduction and immobilization and is being studied in a DOE Environmental Management Science Program (EMSP) project for applicability to leak mitigation through the immobilization of technetium and uranium. Applied to a tank farm, this technology could create a permeable reactive barrier to mitigate future tank leaks. Alternatively, it could directly treat the technetium and uranium associated with an existing leak. Radon displacement also appears to have significant potential. Under this concept, detection of naturally occurring radon displaced from the soil column by a tank leak would be indicative of that leak. Several other approaches are possible but have not yet been demonstrated as viable at the laboratory level. These include tank waste vapors (leak detection by measuring trace radioactive gases or volatile vapors emanating from tank waste) and reactive tracers (leak detection and monitoring by tracers that change chemically by contact with tank waste). These technologies are further described in Appendix E.

\subsection{Implementation Considerations}

The actual design and operation of any or all of the SAFE technologies in a tank farm would depend on the results of further development and testing. However, the conceptual implementation design has been established and is likely to be representative of the system that is actually implemented.

The wellfield will use existing cased boreholes near the SST of interest. The casings will be perforated at select intervals, and packer arrangements will provide injection/extraction capabilities at the various intervals. (This same perforation and packer use has been implemented with the cased boreholes at the carbon tetrachloride soil vapor extraction system in the 200 West Area.) The wells around the SST will be connected to hoses run outside the tank farm fence to the blower skid and field laboratory. No activities should need to be performed within the tank farm itself after the initial setup of the wells.

The operations of the SAFE technologies are anticipated to be such that each of the wells would be used for air injection or extraction at various times, providing full coverage of the area underlying a tank. The tracers or reactive gases could be injected or extracted from any of the wells using valves on the blower skid. (The one exception would be the in-tank tracer, which would be mixed with the tank retrieval liquid as part of retrieval operations.) The collection and analysis of the extracted vapor would take place in the onsite laboratory trailer and would be supplemented by samples collected and transported to a fixed laboratory (such as for analysis of the triple-sorbent tubes by GC/MS). Therefore, implementing SAFE technologies would not interfere with tank farm activities and would provide a means of detecting and mitigating tank leaks.

The suite of SAFE technologies represents a diverse set of tools for tank leak detection, monitoring, and mitigation. All of the technologies are complementary, using the same wells, flowfield, and infrastructure. They can be deployed in a tank farm using existing cased boreholes. By virtue of their physiochemical basis, they could be implemented without any potential electrical interference or specific safety issues or concerns. 


\subsection{References}

\subsection{Cited References}

Barnett DB, GW Gee, and MD Sweeney. 2002. Results of Tank-Leak Detection Demonstration Using Geophysical Techniques at the Hanford Mock Tank Site-Fiscal Year 2001. PNNL-13818, Pacific Northwest National Laboratory, Richland, Washington.

Deeds N, G Pope, and D McKinney. 1999. "Vadose Zone Characterization of a Contaminated Field Site Using Partitioning Interwell Tracer Technology.” Environmental Science and Technology, Vol. 33, No. 16.

Khaleel R and EJ Freeman. 1995. Variability and Scaling of Hydraulic Properties for 200 Area Soils, Hanford Site. WHC-EP-0883, Westinghouse Hanford Company, Richland, Washington.

Levenspiel O. 1972. Chemical Reaction Engineering. John Wiley and Sons, New York.

Washington State Department of Ecology, U.S. Environmental Protection Agency, and U.S. Department of Energy. 1998. Hanford Federal Facility Agreement and Consent Order. Document No. 89-10, Rev. 5 (The Tri-Party Agreement), Olympia, Washington.

\subsection{Bibliography}

Battelle Memorial Institute. 1999. Performance Evaluation Report for Soil Vapor Extraction Operations at the Carbon Tetrachloride Site, February 1992-September 1999; BHI-00720 Rev. 4. Battelle-Pacific Northwest Division, Richland, Washington.

Dwarakanath D, N Deeds, and G Pope. 1999. "Error Analysis of Partitioning Interwell Tracer Tests." Environmental Science and Technology Vol. 33 No. 21.

Gee G and A Ward. 2000. Vadose Zone Transport Field Studies-FY 2000: Summary of Activities. Pacific Northwest National Laboratory, Richland, Washington.

Groundwater/Vadose Zone Integration Project. 1999. Preliminary System Assessment Capability Concepts for Architecture, Platform, and Data Management. http://www.bhi-erc.com/projects/vadose/docs/projdocs.htm.

Huckaby JL, JC Evans, KB Olsen, ZI Antoniak, JL Julya, and DS Sklarew. 1999. "He and SF6 as Tracers for Determining Ventilation Rates of High-Level Radioactive Waste Tanks." Nuclear Energy 38(2):99-105. 
Huckaby JL, JC Evans, and DS Sklarew. 1999. "Measurements of the Passive Ventilation Rates of HighLevel Radioactive Waste Tanks Using Tracer Gases", Proc. 25th DOE/NRC Nuclear Air Cleaning and Treatment Conference, Minneapolis. 514-522, NUREG/CP-0167, CONF-980803.

Jin M, RE Jackson, and GA Pope. May 2000. “The Interpretation and Error Analysis of PITT Data." Treating Dense Nonaqueous-Phase Liquids (DNAPLs): Remediation of Chlorinated and Recalcitrant Compounds. The Second International Conference on Remediation of Chlorinated and Recalcitrant Compounds, Monterey, California, pp. 85-92.

Ramirez AL, WD Daily, and A Binley. 2001. Tank Leak Experiment at the Mock Tank Site, 200 East Area: Electrical Resistance Tomography-Preliminary Results. Draft Report. Lawrence Livermore National Laboratory, Livermore, California.

Saripalli KP, PD Meyer, DH Bacon, and VL Freedman. 2001. "Changes in Hydrologic Properties of Aquifer Media Due to Chemical Reactions: A Review." Critical Reviews in Environmental Science and Technology 31(4):311-349.

Westinghouse Hanford Co. 1996. Trade Study of Leakage Detection, Monitoring, and Mitigation Technologies to Support Hanford Single-Shell Tank Waste Retrieval. WHC-SD-WM-ES-379 Rev. 0.

Yoon S, I Barman, A Datta-Gupta, and GA Pope. March 1999. "In-Situ Characterization of Residual NAPL Distribution Using Streamline-Based Inversion of Partitioning Tracer Tests." Proceedings of the 1999 Exploration and Production Environmental Conference, Austin, Texas, pp. 391-400. Society of Petroleum Engineers No. SPE 52729. 


\section{Appendix A}

PITT Technology for Tank Leak Detection

FY 2001 Field Demonstration Test Plan 


\title{
Partitioning Interwell Tracer Test \\ Technology for Tank Leak Detection
}

FY 2001 Field Demonstration Test Plan

August 10, 2001

\author{
Richard J. Cameron, P.E. \\ John C. Evans, Ph.D. \\ Michael D. Johnson \\ Khris B. Olsen
}

Pacific Northwest National Laboratory

Duke Engineering \& Services

Richard E. Jackson, Ph.D.

Hans Meinardus, P.G.

Neil Deeds, Ph.D.

University of Texas at Austin

Gary A. Pope, Ph.D.

Eric Bruesewitz

\author{
Prepared for \\ the U.S. Department of Energy \\ under Contract DE-AC06-76RLO 1830
}

Pacific Northwest National Laboratory

Richland, WA 99352 


\title{
Appendix A \\ Partitioning Interwell Tracer Test Technology for Tank Leak Detection FY 2001 Field Demonstration Test Plan
}

\begin{abstract}
A.1 Introduction
The Partitioning Interwell Tracer Test (PITT) technology is one of a suite of candidate Leak Detection, Monitoring, and Mitigation (LDMM) systems that may be used in support of Hanford tank waste retrieval operations. The PITT technology demonstration described in this test plan is a proof-ofconcept field demonstration designed to determine limits of sensitivity, minimum detectable effluent volume, and time-to-detection for tank-leak scenarios based on retrieval performance evaluation (RPE) methodology (Memorandum of Understanding; DOE/Ecology 1996). Design criteria of 95\% Probability of Detection (PD) and 5\% Probability of False Alarm (PFA) have been specified by LDMM Functions and Requirements documents.
\end{abstract}

\section{A.1.1 PITT Technology Demonstration Objectives}

Formal PITT technology demonstration objectives are defined by the Ex-Tank Leak Detection and Leak Monitoring Technologies Test Specification RPP-8476, Rev. 1 (Vista Engineering, Inc. 2001). Emphasis in this demonstration was on leak detection within the zone of interrogation, rather than on quantification of the total leak volume.

Tank leak scenarios specified for the LDMM geophysical methods demonstration form the basis for the PITT demonstration. Five releases of $36 \mathrm{wt} \%$ sodium thiosulfate solution will occur at the Mock Tank Site with simulated leak rates varying from approximately 10 to $60 \mathrm{gph}$. The volume for each release will vary from 500 to 1500 gal, with a total release volume of 4000 gal. The intent is to perform enough partitioning tracer tests to verify "proof of concept" of the PITT technology as it applies to leak detection. A preliminary conservative interwell tracer test (CITT) will be conducted in conjunction with a background PITT to verify flowfield parameters and tracer capture. These tests will begin prior to stimulant release beneath the Mock Tank Structure. In-tank tracer tests (ITTTs) will also be performed by sparging the sodium thiosulfate solution with soluble tracer compounds such that they will be transported by the PITT air-advection flowfield and detected using PITT analysis equipment.

\section{A.1.2 Overview of Design Approach}

The PITT technology uses the principle of chromatographic separation through partitioning-induced flow retardation of reactive versus conservative tracers to quantify moisture changes in the swept zone. Elution curves of tracer concentration are subjected to first-temporal-moment analysis to provide quantitative information on the substance of interest, and the data can be used with inverse modeling codes to provide more detailed information on location and concentrations. Inverse modeling requires approximately 1 to 10 hours of processing time, depending on the degree of detail desired. PITT is one of the few subsurface characterization technologies that integrate over a large soil volume, potentially 
eliminating the need for expensive "pincushion" sampling networks that often fail to adequately represent the subsurface. The PITT technology is also the only subsurface characterization technique that does not rely on electrical or electromagnetic methods, which are subject to interference from subsurface or aboveground metallic objects such as tanks, pipes, or power lines.

In this field demonstration of the PITT technology, the zone underneath the Mock Tank Structure will be swept by an air-advection flowfield into which tracer gases with varying partitioning coefficients $\left(\mathrm{K}_{\mathrm{i}}\right)$ will be injected periodically (Figure A.1). Flowfield monitoring and/or extraction wells will be sampled to monitor tracer concentration as a function of time. The tracer elution curves will be analyzed by the first-temporal-moment method. The quotient of the curve centroids $\left(t_{\mathrm{p}} / \mathrm{t}_{\mathrm{n}}\right.$, equal to the retardation factor $\left.\mathrm{R}_{\mathrm{f}}\right)$ and the partitioning coefficients $\left(\mathrm{K}_{\mathrm{i}}\right.$, equal to the ratio of equilibrium concentrations in the two phases of interest $\mathrm{C}_{\mathrm{i} \text {, air }} / \mathrm{C}_{\mathrm{i} \text {, water }}$ ) of the partitioning tracers will be used to establish a baseline of soil-water saturation $\left(\mathrm{S}_{\mathrm{W}}\right)$ (Figure A.2). Any increase in saturation measured by subsequent PITTs will indicate a leak.

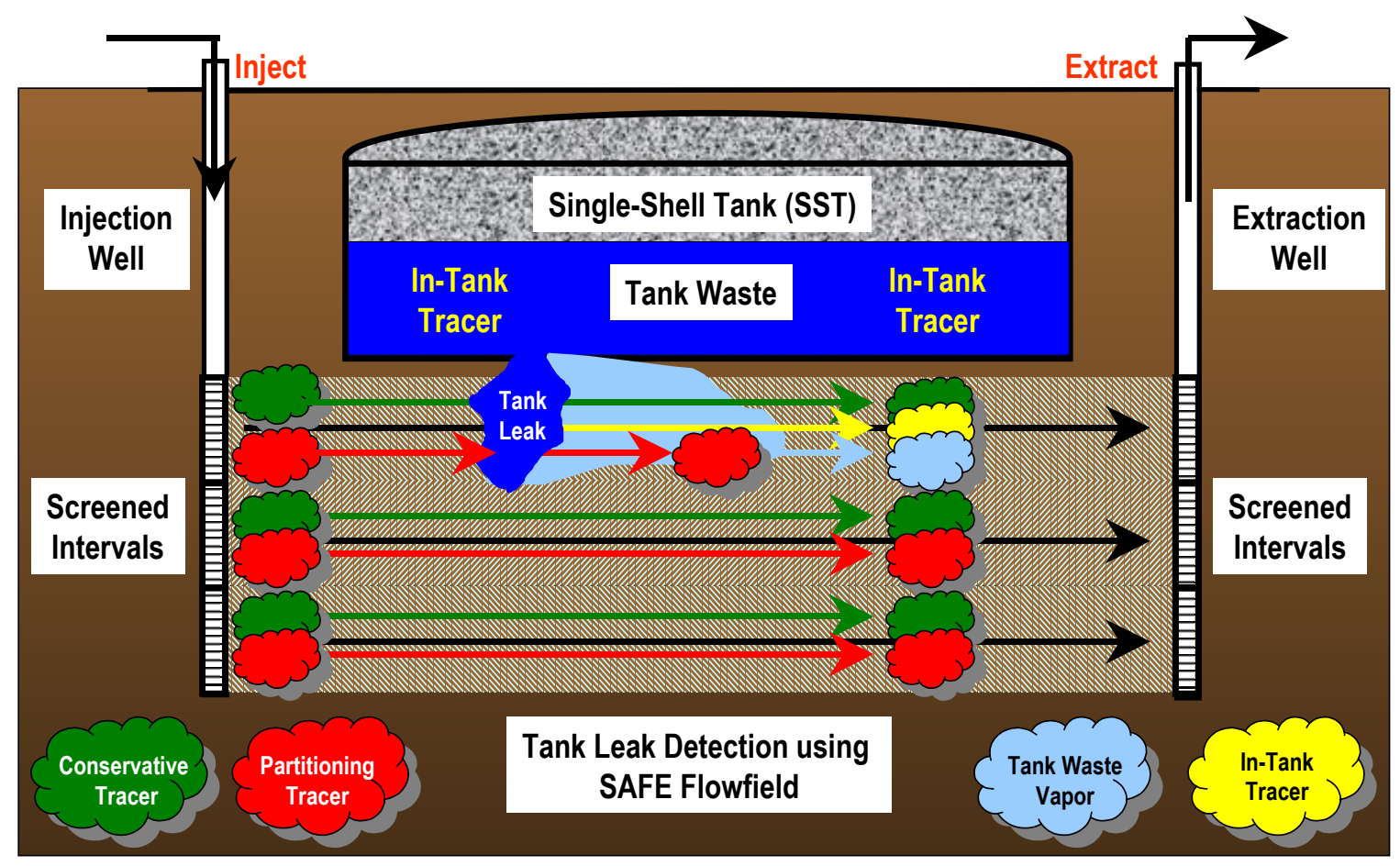

Figure A.1. Transport of Conservative and Partitioning Tracers, In-Tank Tracers, and Tank-Waste Vapors Through Advective Flowfield. Note retardation of partitioning tracer during passage through tank waste. In-tank tracers (chloro/fluorocarbons, $\mathrm{N}_{2} \mathrm{O}$ ) will also be swept through the flowfield and will provide qualitative indication of a leak, as will perturbations of the conservative tracer elution curve caused by leak-induced porosity changes.

The first-temporal-moment analysis method for evaluating PITT data is very robust and relatively unaffected by soil anisotropies; site soil morphology and geology have little, if any, effect on the PITT. Test factors that may affect data analysis include variations in tracer flow rate, variations of the tracer partitioning coefficient due to changing chemical composition of the leaked substance, and detection limit and analytical errors introduced by the gas chromatograph (GC). Steps were taken to reduce the impact 
of these factors on the test results; the tracer flow rate was monitored and logged, laboratory studies tracked progress to quantify the effect of waste composition on tracer partitioning coefficients, and "best practice" analytical procedures for the GC were used.

The PITT air-advection flowfield was used with collateral leak-detection methods such as an in-tank tracer (difluoromethane, chlorodifluoromethane, or nitrous oxide) added during waste-dissolution operations or radon emanating from the soil-column displacement by aqueous influx (see Figure A.1).

Additionally, the conservative tracer elution curves were analyzed for perturbations resulting from leakinduced porosity changes in the swept pore volume under the tank, as discussed in Section 3.6 of the main report.

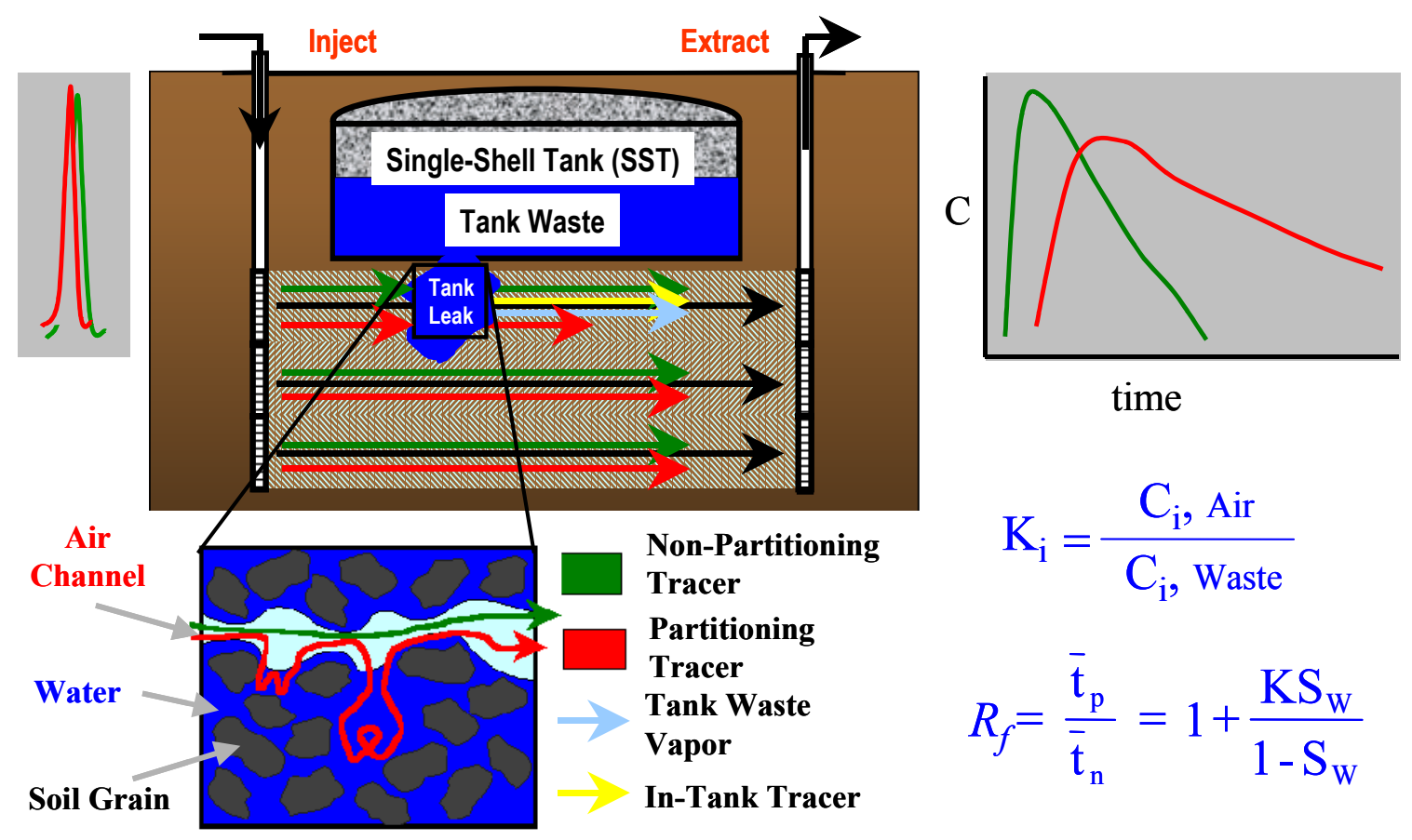

Figure A.2. Basic Calculations for PITT Data Analysis. The variable $t_{i}$ represents the first temporal moments (centroids of the curves shown at upper right) of the tracer-elution curves (partitioning and non-partitioning); other variables include:

$\mathrm{C}_{\mathrm{i}, \mathrm{p}}=$ Concentration of substance $\mathrm{i}$ in the $\mathrm{p}$ phase

$\mathrm{K}_{\mathrm{i}}=$ Partition coefficient of substance $\mathrm{i}$ between the two phases of interest

$\mathrm{R}_{\mathrm{f}}=$ Retardation factor

$\mathrm{S}_{\mathrm{w}}=$ Saturation $(\mathrm{vol} / \mathrm{vol})$ of water in soil.

The application of tracer technologies to tank-leak detection will require characterization of stratigraphy and pneumatic conductivity, column and flow tests to quantify tracer behavior in the presence of ionic tank waste solutions, modeling using UTCHEM simulations to verify wellfield design and flow parameters, CITTs to verify pneumatic control and tracer capture, and background PITTs to measure ambient soil moisture in the swept pore volume of interest. ITTTs will also be performed to test the viability of the in-tank tracer concept and develop improved tracers and analytical techniques for ITTT applications. 


\section{A.1.3 Interfacing and Collaboration with Geophysical Methods Demonstration}

The PITT technology demonstration will be deployed simultaneously with a geophysical methods demonstration. As such, wellfield installation and other site modifications will be coordinated with the demonstration to the extent possible. Efforts will also be made to avoid potential radio frequency/ electrical interference issues arising from PITT operations.

\section{A.1.4 Description of the Mock Tank Structure and Technology Development Area (TDA)}

The Mock Tank Site is located in the 200 East Area, east of B-Plant and across $7^{\text {th }}$ Street from the Strontium Semi-Works (Figure A.3). The site was constructed in April to June 1994 and was used for testing the electrical resistance tomography (ERT) technology. It features a circular, steel walled, Mock Tank Structure that is $50 \mathrm{ft}$ in diameter and $11 \mathrm{ft}$ high, seated on a 4- to 6-in. concrete footer, with a $1 / 8$ in. floor tack-welded out of sheet steel to approximate the electrical characteristics of a single shell tank bottom (Figure A.4). Sixteen 6-in.-diameter, 40-ft-deep boreholes with PVC casings, were installed around the Mock Tank Structure for evaluating ERT-based leak-detection technologies. Two 2500-gal tanks are visible at the right of the figure; these were used to hold water or leak simulant solution.

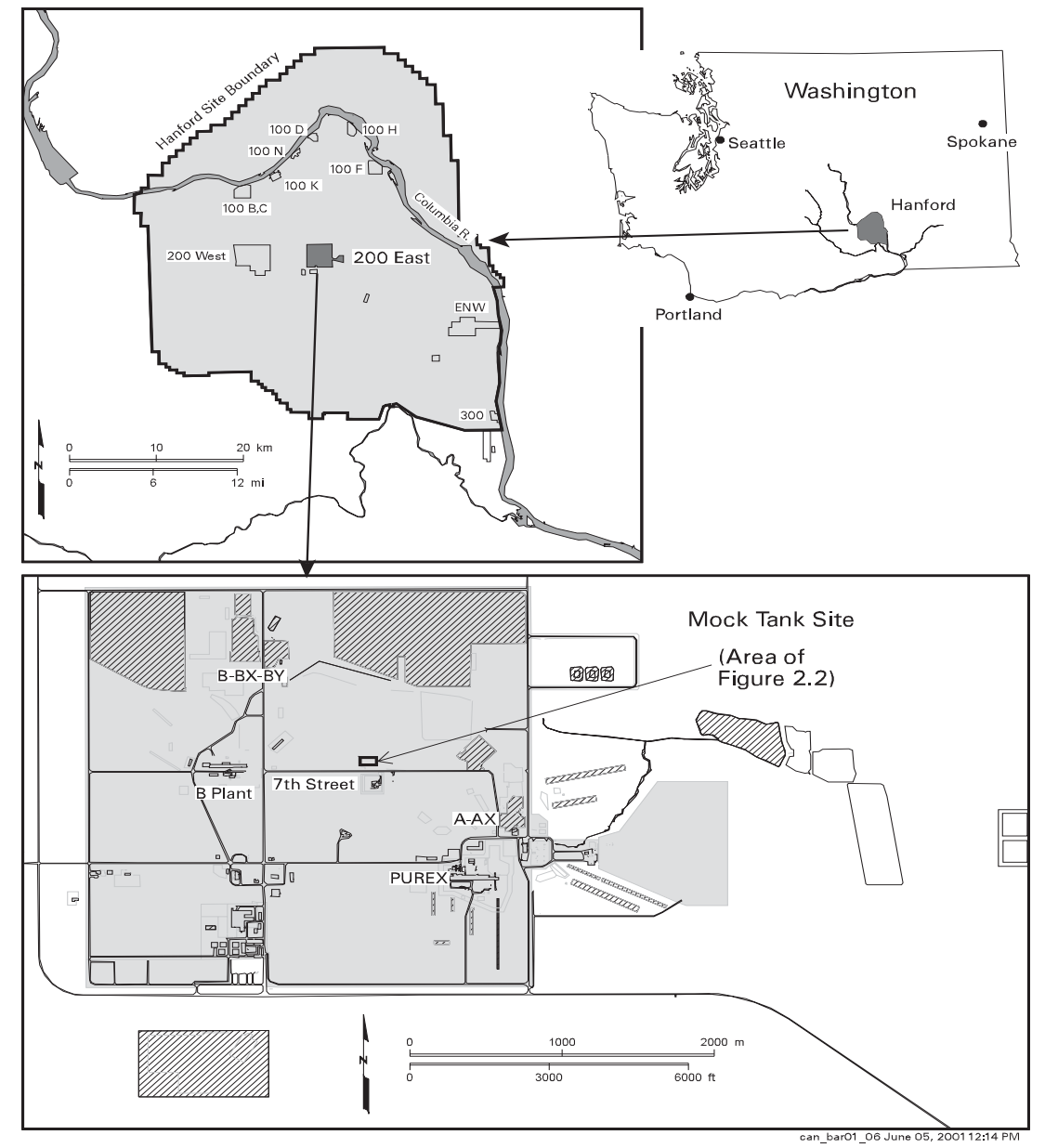

Figure A.3. Location of the Mock Tank Site on the Hanford Site 
The Technology Development Area (TDA) is directly east of the Mock Tank Structure (Figure A.5). It will be used for development of tracer suites, analysis techniques, and design iterations for the PITT technology demonstration. The PITT technology demonstration will take place at the Mock Tank Structure along with the geophysical methods demonstration. Seven cone penetrometer (CPT) wells (four vadose zone wells and three liquid infiltration points) will be installed in a linear array at the TDA for CITT/PITT/ITTT development activities. Five CPT wells (four vadose zone wells and one liquid infiltration point) will compose the infiltration gallery (IG) at the southeast corner of the TDA; these will be used in a time-to-depth leak-migration experiment. Three additional CPT boreholes will be emplaced around the Mock Tank Structure for characterization purposes. A conventional borehole will be drilled in the northern part of the TDA to provide characterization data. Nine 4-in.-diameter wells will be drilled adjacent to the Mock Tank Structure. These will be configured in three triangular arrays of three wells each and will serve as air injection, monitoring, and extraction wellfields from east to west, respectively. These wells will be numbered according to their screened interval and function. For example, 2030I is an injection well screened from 20 to $30 \mathrm{ft}$ below ground surface (bgs). Additional details on the wellfields follow.



Figure A.4. Photograph of the Mock Tank Site 


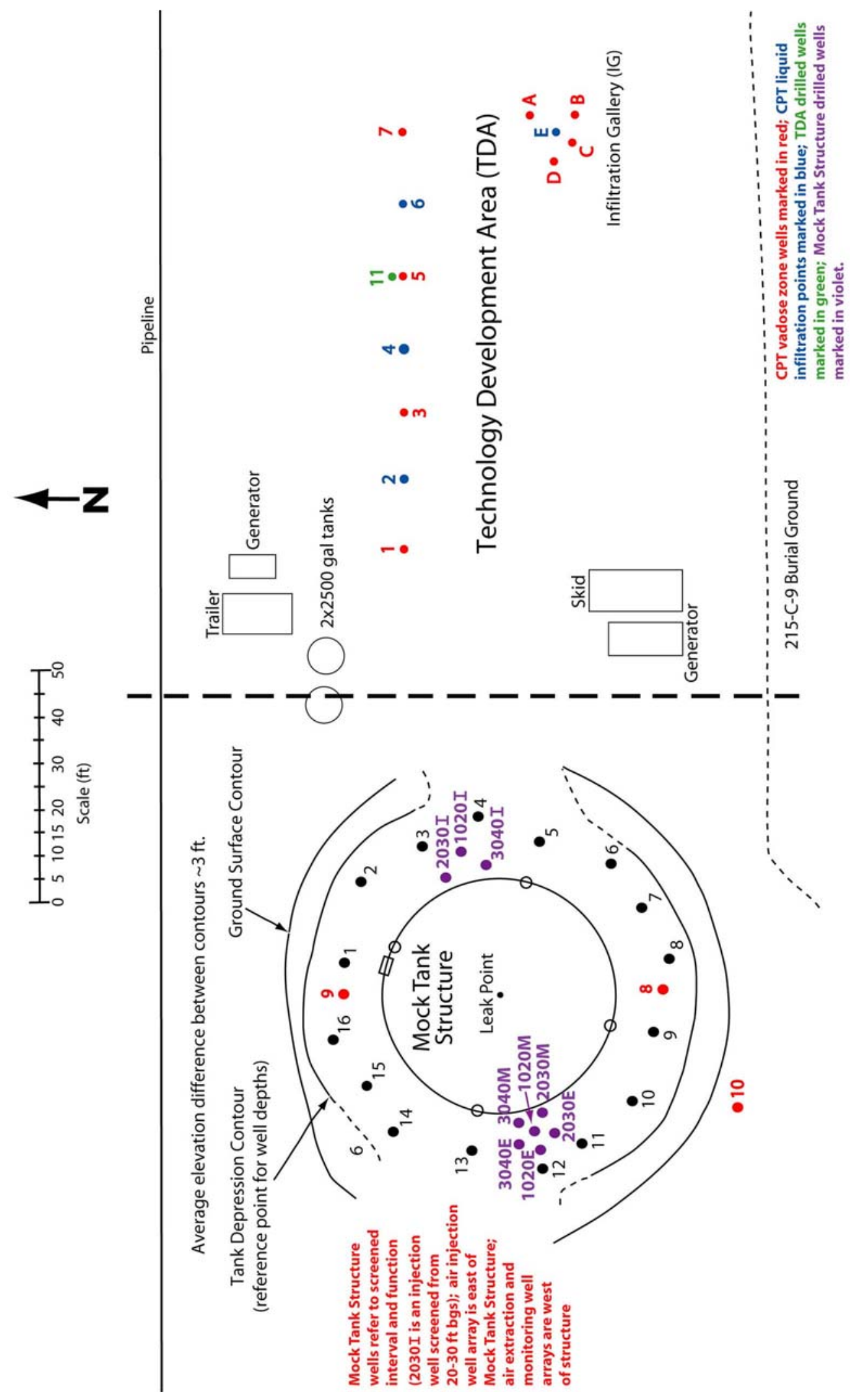

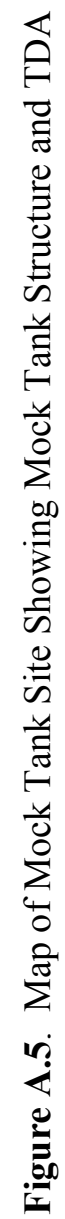




\section{A.2 PITT Field Operations-Site Planning and Construction Activities}

Borehole and leak-point emplacement will be the primary construction activities at both the Mock Tank Structure and the TDA. Numerous preparative activities are required before construction activities can begin. These activities are described below.

\section{A.2.1 Permitting and Site Surveys}

Biological and cultural resource surveys have been carried out and approval for project activities has been issued by the appropriate authorities. The site was previously surveyed and reviewed for construction in 1994 and no significant changes were noted from that time until the present.

\section{A.2.2 Environmental Controls}

A liquid discharge permit for the 4000 gal of $36 \mathrm{wt} \%$ sodium thiosulfate solution to be used in the PITT technology and geophysical methods demonstrations has been issued to the geophysical methods demonstration team. TDA activities require simulated leak testing and may require using both treated water and $36 \mathrm{wt} \%$ sodium thiosulfate solution. Discharge permits have been issued for 5200 gal of treated water and 4200 gal of thiosulfate solution to support these activities.

Chlorinated and/or fluorinated containing aliphatic carbon compounds will be used as both PITT and in-tank tracers (methane may be used as a conservative tracer). The low concentrations and total discharge-to-air quantities are within Hanford Site permit levels. Additionally, inert gases such as neon may be used as conservative tracers; these gases are not environmentally significant and are not regulated at the levels proposed during PITT tests. Diesel generators to be used at the site will be allowed under an existing Hanford Site air-discharge permit.

\section{A.2.3 Industrial Safety and Occupational Health Plan Implementation}

The Industrial Safety and Occupational Health (IS\&OH) planning is being carried out by the site Safety Engineer and will be implemented according to Hanford site standards; no unusual hazards are expected in the performance of the PITT testing. An underground radioactive materials area, 218-C-9 Burial Ground, is adjacent to the Mock Tank Site (see Figure A.5), but previous surveys have determined no radiological hazard is present. A radiological survey will be performed when subsurface work is initiated; standard decontamination procedures will be carried out on any drilling or CPT equipment used. An approved Job Hazard Analysis and an approved Safety and Hazard Mitigation Plan are included as Attachments A and B, respectively.

\section{A.2.4 Site Characterization Activities}

A CPT will be mobilized to the site by late June 2001 to carry out lithologic characterization, sample collection, and pneumatic testing activities. Samples will be analyzed for grain-size distribution and soil moisture; they will also be used in laboratory column tests for tracer development. A thiosulfate 
injection/neutron logging experiment designed to measure time-to-depth of an approximately 400-gal thiosulfate injection will take place at the IG and will be used in the design of the TDA wellfield.

\section{A.2.5 Provision of Site Utilities}

Electrical service will be provided by up to four diesel generators ranging from 15 to $75 \mathrm{~kW}$. Process water will be contained in the two 2500-gal tanks used in the earlier ERT experiments at the site. Water for drinking and sanitary use, as well as sanitary facilities, will be provided by an appropriate subcontractor prior to initiating site construction activities.

\section{A.2.6 Modifications to the TDA}

Twelve 2-in.-diameter boreholes will be emplaced by CPT within the TDA. A linear array of seven CPT boreholes will form the nucleus of the TDA; four will be completed with PVC casings to $35 \mathrm{ft}$ bgs and screened intervals from 25 to $35 \mathrm{ft}$; three will be completed to $8 \mathrm{ft}$ bgs as liquid-injection points with screened intervals from 5 to $8 \mathrm{ft}$ bgs (see Figure A.5). An IG will be constructed in the southeast corner of the TDA for a leak-migration time-to-depth experiment using neutron logging. Four CPT boreholes will be completed to a depth of approximately $40 \mathrm{ft} \mathrm{bgs} \mathrm{(with} \mathrm{closed-end} \mathrm{PVC} \mathrm{casings)} \mathrm{around} \mathrm{a} \mathrm{central}$ liquid-injection point completed to $8 \mathrm{ft}$ bgs with a screened interval from 5 to $8 \mathrm{ft}$ bgs. An additional 4-in.-diameter borehole will be drilled immediately north of the linear array for pneumatic conductivity testing purposes.

\section{A.2.7 Modifications to Mock Tank Structure}

Three 2-in.-diameter CPT boreholes will be installed around the Mock Tank Structure for characterization purposes. Core samples will be collected and characterized. Nine auger installed PVC-cased boreholes will be completed at depths of up to $40 \mathrm{ft}$ surrounding the Mock Tank Structure. These boreholes will form a wellfield consisting of three triangular arrays (injection, monitoring, and extraction) with each array including three boreholes with 10-ft screened intervals (10 to $20 \mathrm{ft}, 20$ to $30 \mathrm{ft}$, and 30 to $40 \mathrm{ft}$ ) (see Figure A.5). These wells are numbered according to their screened interval and function (2030I is an injection well screened from 20 to $30 \mathrm{ft} \mathrm{bgs).} \mathrm{Each} \mathrm{well} \mathrm{in} \mathrm{the} \mathrm{injection} \mathrm{array} \mathrm{will} \mathrm{be} \mathrm{aligned}$ through the tank centerpoint with the monitoring and extraction well array members with the same screened interval on the opposite side of the tank.

\section{A.3 PITT Field Operations}

PITT field operations will generally be carried out in the following order:

1) Coordination and planning

2) Site characterization activities

3) Wellfield installation

4) CITT

5) Background PITTs to measure ambient soil moisture

6) Tank-leak detection PITTs/ITTTs 


\section{A.3.1 Coordination and Planning}

The following coordination and planning activities will be undertaken to ensure the PITT technology demonstration is successful.

- Coordination of field activities with the geophysical methods demonstration.

- Identification and allocation of labor resources for the duration of the field work.

- Identification and procurement of tracers, scheduling of production (if necessary), and shipment.

- Identification and procurement of necessary tracer handling, injection, and analysis equipment.

- Scheduling and coordination of housing, travel, and other personnel issues.

- Mobilization of personnel and equipment.

\section{A.3.2 Flowfield/Control Equipment Deployment and Testing}

Blowers, valves, sensors, and plumbing will be deployed with ample time for testing and correction of any defects that may impact test performance. Data-logging systems and sensing equipment will be tested as part of the flowfield control system. System performance, as well as flowfield control, tracer capture, and geosystem parameter confirmation, will be demonstrated prior to beginning leakmeasurement PITTs. Flow rates from 10 to 50 SCFM will be utilized in PITT/ITTT operations.

\section{A.3.3 Analytical Equipment Deployment and Testing}

Analytical equipment to be deployed at the test site includes two GCs (Buck Scientific Model 610, HP Model 5890) with sampling loops; a flame ionization detector (FID) and an electron capture detector (ECD) will be used to detect various types of tracers (PITT/ITTT). Both GCs are equipped with GSGasPro 0.32-mm columns. Additionally, an MTI gas-sampling GC will be used for analysis of neon tracer to be used during CITTs and as a possible part of PITT tracer suites. Analytical equipment and analysis protocols will be tested and calibrated before deployment; equipment tests will continue after deployment and before PITT/ITTT operations commence to ensure reliable tracer-concentration analysis.

\section{A.3.4 Technology Development Area CITT}

A CITT will be carried out at the PTDA well array before commencement of PITT activities, using neon as the conservative tracer and the MTI GC as the analysis instrument. The CITT will serve to verify flowfield control, tracer capture, and site characterization parameters, as well as verify proper flowfieldcontrol and tracer-analysis system operation.

\section{A.3.5 TDA PITT/ITTT Operations}

Development operations at the TDA will serve as design iterations for the PITT activities during the technology demonstration at the Mock Tank Structure. An infiltration experiment will be performed using neutron logging to monitor migration time/depth of an approximately 350 -gal sodium thiosulfate solution (36 wt\%) injection for test design purposes. Well-screen length and depth parameters for follow- 
on activities may be modified if results warrant. At present, the combined tracer suite (PITT/ITTT) consists of chloro/fluorocarbons, neon, and methane with injection concentrations in the 1,000 ppmv range. The reduced size of the development-area PITT/ITTT wellfields allow a PITT/ITTT to be carried out in approximately 30 hours; the wellfield is designed to allow repeated measurements of simulated leak saturations beginning from a background-level soil-moisture content.

An ITTT will be carried out during a water injection into the linear array flowfield after a background PITT and prior to the commencement of PITT development operations. The ITTT will be carried out using nitrous oxide as the (simulated) in-tank tracer; this compound is already present in many SSTs and is soluble enough in saline solutions to warrant its investigation as an expedient in-tank tracer. Approximately 400 gal of water will be sparged with nitrous oxide before the water is injected prior to PITT development operations; the nitrous oxide will be detected using the same GC analysis equipment used for PITT operations.

\section{A.3.6 Mock Tank Structure CITT}

A CITT will be carried out at the Mock Tank Structure wellfield as part of the initial background PITT (due to time constraints). As at the TDA, the CITT will serve to verify flowfield control, tracer capture, and site characterization parameters; it will also serve as a system test for the PITT technology demonstration effort.

\section{A.3.7 Mock Tank Structure PITT/ITTT Operations}

PITT operations at the Mock Tank Structure will be coordinated with the geophysical methods demonstration. A background PITT to measure ambient soil moisture will be carried out in the week preceding simulated-leak solution injections, with sufficient PITTs being carried out during the demonstration activities to verify "proof-of-concept" of PITT technology applications to tank-leak detection. The leak interval(s) will consist of five periods of injections (varying from 500 to 1,500 gal each) of $36 \mathrm{wt} \%$ sodium thiosulfate solution from the central leak-point in the Mock Tank Structure, with actual leak aliquots and timing as stated in the finalized test specifications. The tracer suites will be determined from TDA activities and laboratory tests but are expected to consist of chloro/fluoro carbons, methane, and possibly noble gases, with injection concentrations in the 1,000 ppmv range. Chloro/fluorocarbons will also be used as (simulated) in-tank tracers for performing ITTTs; the sodium thiosulfate solution will be sparged with the tracer before each injection begins.

\section{A.3.8 PITT/ITTT Data Analysis Techniques}

First-temporal-moment analysis and inverse-modeling techniques (as described in section 1.3) will be used to analyze PITT data from GC analysis plots of tracer concentration vs. time. These results will be compared with results from the geophysical methods demonstration. A hard-copy printout of each analytical run will be made for recording purposes, as well as backup electronic media copies. Each analytical run will be identified by date, time, sampling location, variables and values measured, and units. Data on ambient temperature, barometric pressure, precipitation, and humidity will be obtained from the Hanford Meteorological Station. 
Preliminary tracer-transport simulations have been carried out by Duke Engineering \& Services using UTCHEM, a three-dimensional multiphase flow and transport simulator developed at the University of Texas at Austin. UTCHEM has been used in the design of numerous PITTs and subsurface surfactant floods and has proven to be a reliable subsurface flow and transport code; it is currently part of the EPA Center for Subsurface Modeling Support suite.

Geosystem parameters for the UTCHEM simulation were estimated using vadose-zone soil characteristics described in the Performance Evaluation Report for Soil Vapor Extraction Operations at the Carbon Tetrachloride Site, February 1992-September 1999; BHI-00720 Rev. 4., and the Preliminary System Assessment Capability Concepts for Architecture, Platform, and Data Management web document from the Groundwater/Vadose Zone Integration Project. A uniform water saturation of 0.10 (v/v) was assumed throughout the simulated flowfield.

A 2800-gal tank leak was simulated by increasing the water saturation to $0.9(\mathrm{v} / \mathrm{v})$ in a $15 \mathrm{x} 15 \mathrm{x} 7 \mathrm{ft}$ grid in a layer beneath the tank; Figures A.6 and A.7 compare the baseline tracer-elution curves to those produced by the simulated tank leak. Both partitioning and conservative tracers were affected; the conservative tracer responded to the reduced air permeability caused by the leak (Figure A.6), and the partitioning tracers were further retarded by the increased water saturation (Figure A.7).

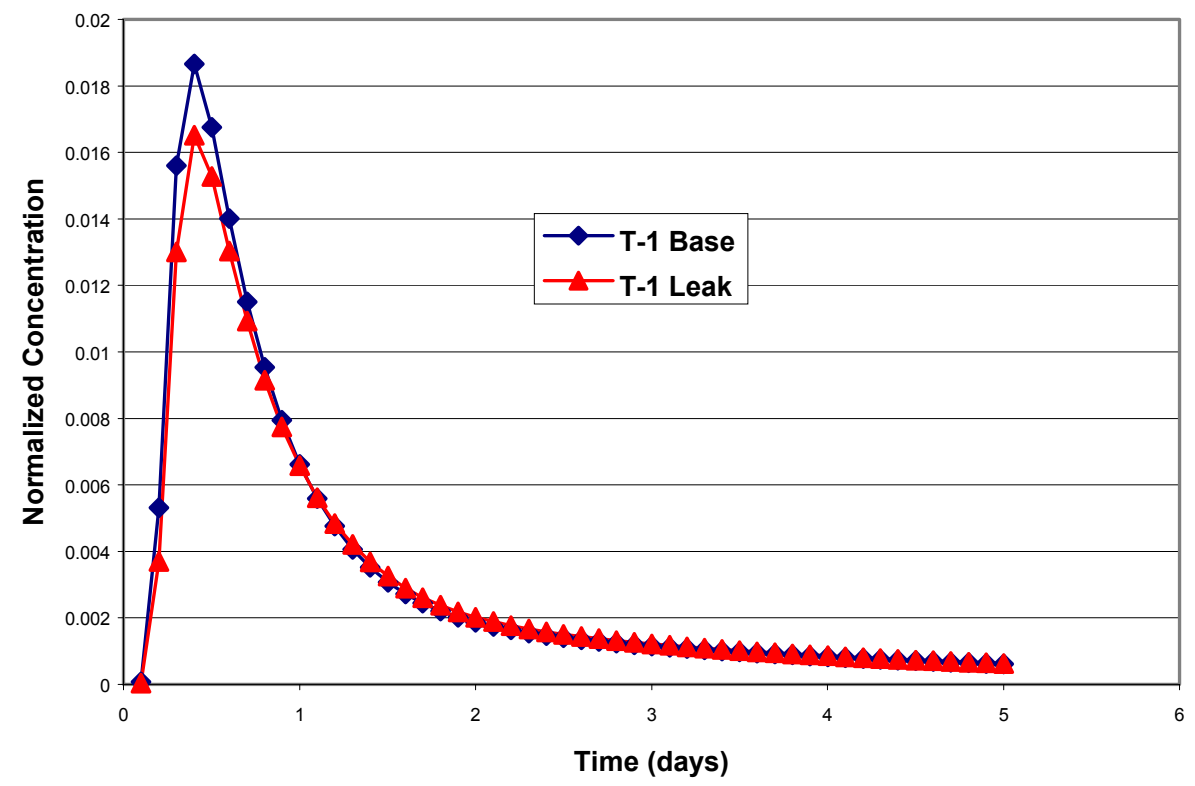

Figure A.6. UTCHEM simulation of conservative tracer behavior after tank leak. The difference between curves is due to permeability changes in flowfield, not partitioning behavior; this property is under investigation as an early leakdetection method. 


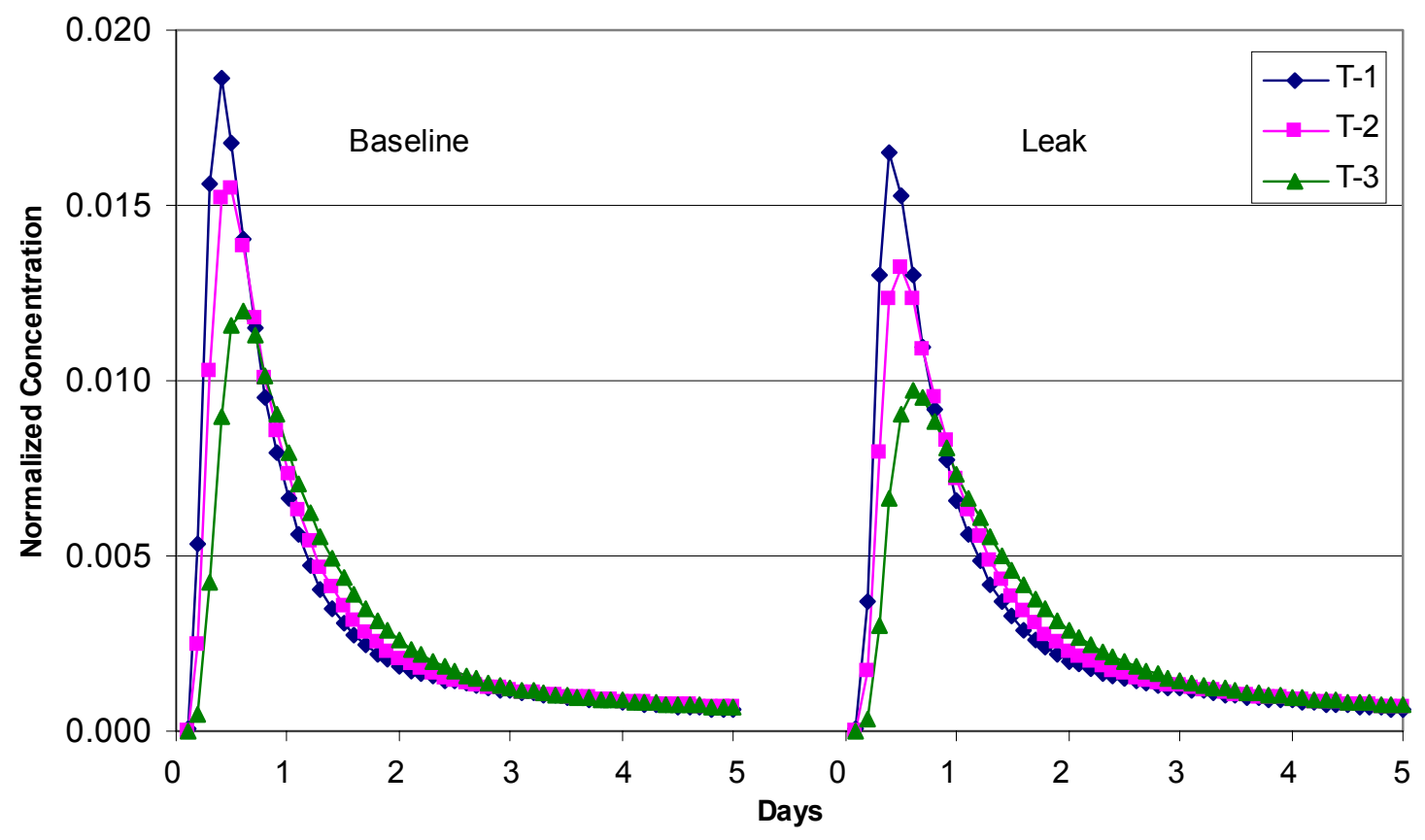

Figure A.7. Comparison of UTCHEM Simulations of Tracer Behavior under Baseline and TankLeak Conditions (change in peaking behavior is evident early in elution curve; note substantially decreased peak concentrations of partitioning tracers 2 and 3 )

\section{A.4 References and Bibliography}

Battelle Memorial Institute. 1999. Performance Evaluation Report for Soil Vapor Extraction Operations at the Carbon Tetrachloride Site, February 1992-September 1999; BHI-00720 Rev. 4.

Deeds N, G Pope, and D McKinney. 1999. "Vadose Zone Characterization of a Contaminated Field Site Using Partitioning Interwell Tracer Technology.” Environmental Science and Tech Vol. 33, No. 16.

Dwarakanath D, N Deeds, and G Pope. 1999. "Error Analysis of Partitioning Interwell Tracer Tests." Environmental Science and Tech 33(21):16.

Gee G and A Ward. 2000. Vadose Zone Transport Field Studies-FY 2000: Summary of Activities. Pacific Northwest National Laboratory, Richland, Washington.

Groundwater/Vadose Zone Integration Project. Preliminary System Assessment Capability Concepts for Architecture, Platform, and Data Management. Web document: http://www.bhierc.com/projects/vadose/docs/projdocs.htm (1999).

Jackson RE. Personal communication to Richard J. Cameron 11/6/2000. 
Khaleel R and EJ Freeman. 1995. Variability and Scaling of Hydraulic Properties for 200 Area Soils, Hanford Site. WHC-EP-0883, Westinghouse Hanford Company, Richland, Washington.

Majer EL, KH Williams, and JE Peterson. 2000. High Resolution Imaging of Vadose Zone Transport using Crosswell Radar and Seismic Methods. LBNL-47465, Lawrence Berkeley National Laboratory, Berkeley, California.

Ramirez A, W Daily; A Binley; D LaBrecque and D Roelant. 1995. Detection of Leaks in Underground Storage Tanks Using Electrical Resistance Methods. UCRL-JC-122180; Lawrence Livermore National Laboratory, Livermore, California.

U.S. Department of Energy and Washington State Department of Ecology. 1996. Memorandum of Understanding. DOE-RL and Ecology, Richland, Washington.

Vista Engineering, Inc. 2001. "Ex-Tank Leak Detection and Leak Monitoring Technologies Test Specification.” RPP-8476 Rev. 1, Vista Engineering, Inc., Kennewick, Washington.

Westinghouse Hanford Co. 1996. Trade Study of Leakage Detection, Monitoring, and Mitigation Technologies to Support Hanford Single-Shell Tank Waste Retrieval. WHC-SD-WM-ES-379 Rev. 0, Richland, Washington.

Yoon S, I Barman, A Datta-Gupta, and GA Pope. March 1999. "In Situ Characterization of Residual NAPL Distribution Using Streamline-Based Inversion of Partitioning Tracer Tests." Proceedings of the 1999 Exploration and Production Environmental Conference. Society of Petroleum Engineers, Austin, Texas, pp. 391-400. 


\section{Attachment A}

\section{Job Hazard Analysis/Safety and Hazard Mitigation Plan}

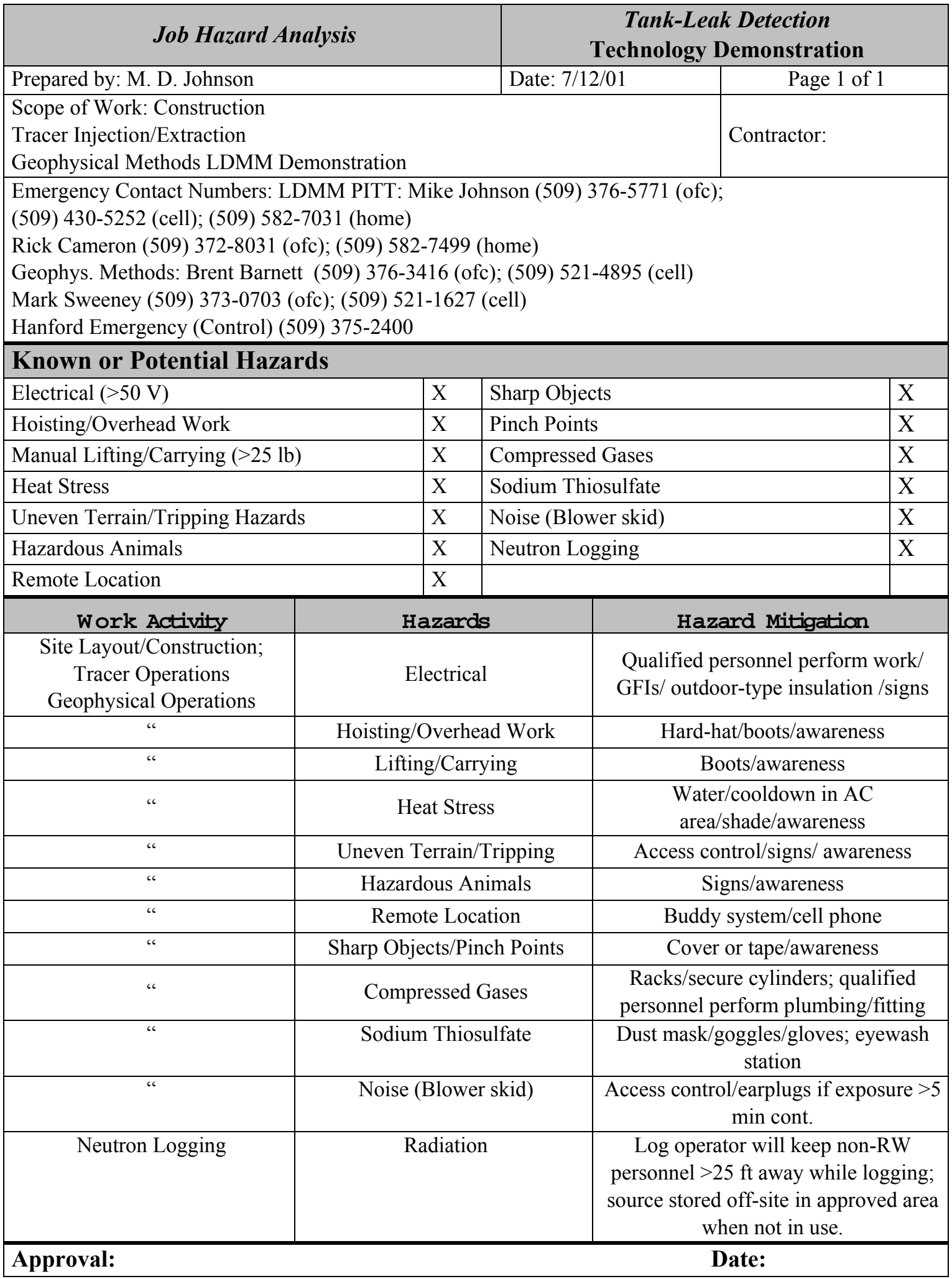




\section{Attachment B}

\section{Safety and Hazard Mitigation Plan}

PNNL Operating Procedure

\begin{tabular}{|c|c|c|}
\hline $\begin{array}{l}\text { Title: Mock Tank Safety \& Hazard } \\
\text { Mitigation Plan }\end{array}$ & \multicolumn{2}{|l|}{$\begin{array}{l}\text { Org. Code: D9T84 } \\
\text { Procedure No.: Mock Tank } 001 \\
\text { Rev. No.: } 0\end{array}$} \\
\hline $\begin{array}{l}\text { Work Location: } \\
200 \text { E Mock Tank }\end{array}$ & $\begin{array}{l}\text { Effective Date: } \\
\text { August 13, } 2001\end{array}$ & \\
\hline Author: Mike Johnson & Supersedes Date: New & \\
\hline \multirow[t]{2}{*}{$\begin{array}{l}\text { Identified Hazards: } \\
\text { Radiological } \\
\text { Hazardous Materials } \\
\text { Physical Hazards } \\
\text { Hazardous Environment } \\
\text { Other: }\end{array}$} & \multicolumn{2}{|l|}{$\begin{array}{l}\text { Are One-Time Modifications Allowed? } \\
\begin{array}{ll}\text { Yes } \quad \text { No }\end{array}\end{array}$} \\
\hline & \multicolumn{2}{|l|}{$\begin{array}{l}\text { Identified Use Category: } \\
\text { Mandatory Use } \\
\text { Reference Use }\end{array}$} \\
\hline Person Signing & Signature & Date \\
\hline \multicolumn{3}{|l|}{ Author } \\
\hline \multicolumn{3}{|l|}{ Technical Reviewer (optional) } \\
\hline \multicolumn{3}{|l|}{ Line or Project Manager (Approval) } \\
\hline \multicolumn{3}{|l|}{ Concurrence as appropriate: } \\
\hline \multicolumn{3}{|l|}{ Safety and Health } \\
\hline Other & & \\
\hline $\begin{array}{l}\text { Review and approve } \\
\text { every } 2 \text { years: }\end{array}$ & & \\
\hline
\end{tabular}




\section{Safety and Hazard Mitigation Plan}

Page 2 of 4

This site has the usual hazards of a construction site. Therefore, similar safety procedures will be used. Visitors must receive a safety briefing and sign in before being permitted on the site. Visitors must be escorted when in work areas (delineated by cordons). All staff working on the site must attend safety meetings and read/sign Job Hazard Analysis (JHA) documents. Material Safety Data Sheets (MSDS) will be available onsite for any applicable substances.

Hazards and mitigation activities are as follows:

Electrical: Only qualified personnel will perform electrical work. Ground-fault interrupters (GFIs) and outdoor-approved insulation will be used on all outdoor circuits. Signs are posted where high voltages are present; do not open access doors on generators or other equipment.

Hoisting/Overhead Work: Always wear a hard-hat and boots when collecting samples at drill rig or when lifting objects that may strike you in the head, even if they are not necessarily "overhead" (PVC pipe lengths $>8$ ' if lifted vertically).

Lifting/Carrying $>50 \mathrm{lb}$ : Lift with your legs, not with your back; obtain help if object to be lifted/moved weighs $>75 \mathrm{lb}$. Make sure that objects to be lifted/carried will not strike other objects and personnel or pinch lifter's/carrier's hands. Do not carry objects that obstruct vision of carrier; obtain assistance with carry. Be aware of tripping hazards when carrying objects; clear area of hazards or obtain assistance with carry if load obstructs vision of foreground.

Heat Stress: Drink adequate amounts of (potable) water or liquids. If overheated, cool down in airconditioned area (trailer). Take regular cool-down breaks when performing heavy labor in hot weather. Use shade tarps/parasols when possible (well logging).

Uneven Terrain/Tripping Hazards: Follow access-control signs and cordons; do not permit visitors unescorted access to work areas. Point out hazards to visitors. Wear boots for ankle support; cover or remove tripping hazards when possible. Be constantly aware of your surroundings and any possible hazards on the ground. Do not carry items that obstruct your vision of your surroundings or of the ground.

Hazardous Animals: Watch for spiders, snakes, or other biting/stinging animals when working with boxes of parts, lengths of pipe, etc. Animals may seek these spaces for coolness during the day, or for warmth at night. At night, do not reach into unlit spaces or walk in unlit areas. Carry flashlight at night.

Remote Location: Use buddy system (two people on site) or keep site cell phone on person; arrange for hourly check-ins by phone if working alone.

Sharp Objects/Pinch Points: Cover or tape sharp objects that cannot be removed; file, tape, or cover surfaces that may present a cutting hazard. Place red hazard ribbon across large pinch points; be aware of 
pinch hazards when lifting or handling objects. Secure large heavy/objects from falling and/or provide positive-clearance barriers ("deadfall blocks").

Compressed Gases: Only qualified personnel will perform work with plumbing or fitting of regulators, etc. All cylinders will be stored in an approved manner; gas cylinders of standard size will be secured to racks; small cylinders will be stored in shipping containers or other secure fashion. MSDSs for tracer gases will be available onsite.

Sodium Thiosulfate: Wear gloves, goggles, and dust mask when handling thiosulfate crystals. Eyewash station is next to the 2500-gal water tanks (see site diagram); personnel will be familiar with operation of eyewash station before handling thiosulfate crystals.

Noise: Earplugs must be worn if personnel remain inside blower-skid area (enclosed by yellow rope) for more than five minutes continuously.

Neutron Logging: Log operators will keep anyone without current RW I training and dosimetry at least $25 \mathrm{ft}$ away from the logging tool or wellhead being logged. The logging tool will be kept in an offsite storage area when not in active operation. The Mock Tank Site is covered under a Hanford site permit for neutron logging. 


\section{Acknowledgement}

By signing this sheet you acknowledge the safety briefing provided by the project representative and this document. You agree to comply with the requirements of this and other relevant procedures, report unmitigated hazards to project management, and report any injury or off-normal event (use 375-2400 for emergency response, and promptly report minor off-normal events to project management).

\begin{tabular}{|c|c|c|c|}
\hline Name (print) & PR\# or HID\# & Signature & Date \\
\hline & & & \\
\hline & & & \\
\hline & & & \\
\hline & & & \\
\hline & & & \\
\hline & & & \\
\hline & & & \\
\hline & & & \\
\hline & & & \\
\hline & & & \\
\hline & & & \\
\hline & & & \\
\hline & & & \\
\hline & & & \\
\hline & & & \\
\hline & & & \\
\hline & & & \\
\hline & & & \\
\hline & & & \\
\hline & & & \\
\hline & & & \\
\hline & & & \\
\hline & & & \\
\hline & & & \\
\hline & & & \\
\hline & & & \\
\hline & & & \\
\hline & & & \\
\hline & & & \\
\hline & & & \\
\hline & & & \\
\hline
\end{tabular}




\section{Appendix B}

\section{Supplemental Laboratory Study Data}




\section{Appendix B \\ Supplemental Laboratory Study Data}

Three series of experiments were carried out as part of the partitioning tracer method activities for the FY 2001 Tank Leak Detection Demonstration (TLDD):

- flow-cell experiments characterizing tracer behavior in a two-dimensional flowfield (Washington State University [WSU])

- packed-column experiments characterizing aqueous-partitioning tracer behavior under fastflow/non-equilibrium conditions (University of Texas-Austin [UT-Austin]).

- packed-column experiments characterizing tracer partitioning coefficients in the presence of saturated salt solutions (PNNL/UT-Austin).

The results of the flow-cell experiments at WSU were summarized in the text of the report (Section 3); the detailed results of the packed-column experiments are given here.

\section{B.1 Tracer Behavior under Fast-Flow Conditions}

This experimental series was composed of eight individual experiments characterizing aqueouspartitioning tracer behavior under varying flow conditions. The experiments employed glass chromatography columns packed with Ottawa sand (F-95 or F-35 grade) on a vibratory shaker that were then brought to a known water-saturation value $\left(\mathrm{S}_{\mathrm{w}} ; \mathrm{vol} / \mathrm{vol}\right)$. Gas-phase tracers were then injected into the column at known concentrations with the eluted concentrations analyzed by gas chromatography (GC) using a flame ionization detector (FID). Tracer experiments were then carried out and tracer data-analysis results compared to $S_{w}$ values measured in the columns.

\section{B.1.1 Verification of Aqueous Partitioning Coefficients}

The first experiment verified aqueous partitioning coefficients for methane and difluoromethane at normal flow rates. A chromatography column (2.54-cm inner diameter; 22.86-cm pack length) was drypacked with F-35 grade Ottawa sand and brought to a residual water saturation of 0.23 by flooding and air flow. Volumetric measurement of the pore volume gave $35.9 \mathrm{~cm}^{3}$; a mass-balance estimate gave a pore volume of $35.4 \mathrm{~cm}^{3}$. Tracer concentrations of $1000 \mathrm{ppm}$ methane and difluoromethane (in dry nitrogen carrier) were injected at a flow rate of $0.14 \mathrm{~cm}^{3} / \mathrm{min}$; tracer slug size was $20.28 \mathrm{~cm}^{3}$. Results of tracerelution analysis are summarized in Table B.1.

The $\mathrm{S}_{\mathrm{w}}$ derived from first-moment analysis of the tracer response curves (Figure B.1) was 0.21, which agrees well with the volumetrically determined $S_{w}$ of 0.23 . Pore volume determined by the conservative tracer-response curve (methane) was $35.9 \mathrm{~cm}^{3}$, which agrees well with the values of $35.9 \mathrm{~cm}^{3}$ (volumetric) and $35.4 \mathrm{~cm}^{3}$ (mass-balance). This experiment was the initial step in adapting partitioning tracers for tank leak detection and quantification. 
Table B.1. Results of Experiment 1

\begin{tabular}{||l|c|c|}
\hline Tracer & Methane & Difluoromethane \\
\hline$\%$ Tracer Recovered & $96 \%$ & $93 \%$ \\
\hline Retardation Factor & 1.00 & 1.44 \\
\hline Static K & 0 & 1.70 \\
\hline Water Saturation & N/A & 0.206 \\
\hline Mean Residence Time (hr) & 4.3 & 3.36 \\
\hline
\end{tabular}



Figure B.1. PITT Tracer Response Curve for Experiment 1

\section{B.1.2 Flow Effects on Tracer Behavior}

This series of seven experiments investigated tracer partitioning behavior under faster flow rates than previously used in vadose-zone PITTs. The first three experiments in this series $(2 \mathrm{~A}, 2 \mathrm{~B}, 2 \mathrm{C})$ were carried out using the same column as in the previous experiment. The column was again dry-packed with F-35 grade Ottawa sand and brought to residual water saturation of 0.238 by flooding and air flow. Volumetric measurement of the pore volume gave $35.9 \mathrm{~cm}^{3}$, and a mass-balance estimate gave a pore volume of $35.4 \mathrm{~cm}^{3}$. Tracer concentrations of $1000 \mathrm{ppm}$ methane and difluoromethane (in dry nitrogen carrier) were injected at flow rates of $0.20 \mathrm{~cm}^{3} / \mathrm{min}, 0.70 \mathrm{~cm}^{3} / \mathrm{min}$, and $2.3 \mathrm{~cm}^{3} / \mathrm{min}$. Tracer slug sizes were regulated by a $17.5 \mathrm{~cm}^{3}$ injection loop. Figure B.2 is a diagram of the apparatus used.

Experiment 2A used a flow rate of $0.20 \mathrm{~cm}^{3} / \mathrm{min}$, yielding a residence time of 3.37 hours. The results of tracer-elution analysis are summarized in Table B.2. The $\mathrm{S}_{\mathrm{w}}$ derived from first-moment analysis of the tracer response curves (Figure B.3) was 0.235 , which compares well with the volumetrically determined $\mathrm{S}_{\mathrm{w}}$ of 0.238 . 


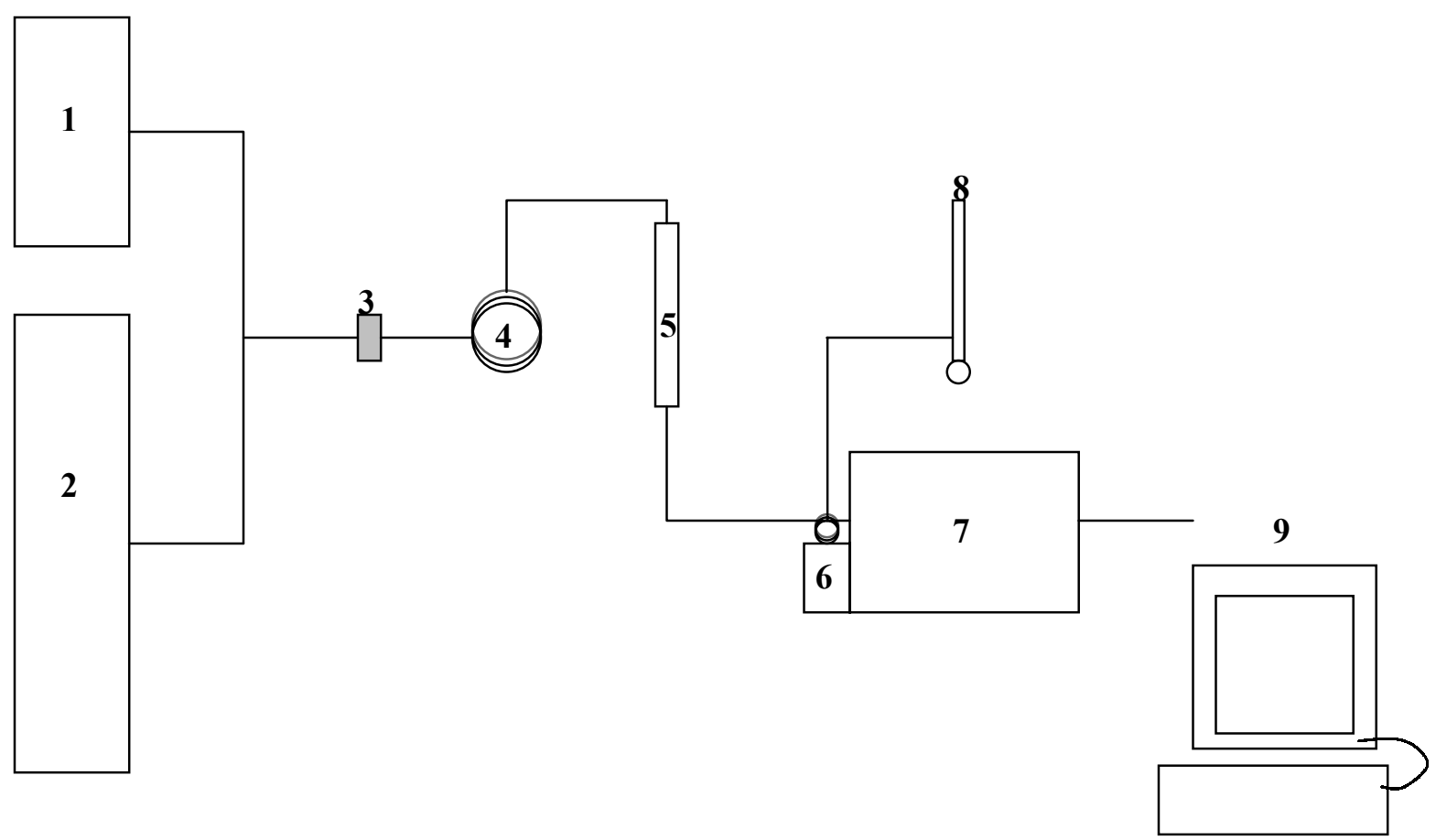

Equipment List:

1. Gas-tracer solution cylinder

2. Nitrogen gas cylinder

3. Porter Instruments VCD-1000 flow controller

4. Injection loop made from $1 / 8$-in. steel tubing

5. Kontes Chromaflex adjustable-length glass column

6. Valco Instrument VICI 10 port G.S.V. with 1-mL sample loop

7. SRI GC model $8610 \mathrm{~B}$ with an $8 \mathrm{ft} \times 1 / 8$ in. Supelco $60 / 80$ Carbopack column and FID

8. Alltech $10-\mathrm{mL}$ bubble meter

9. Dell 450/L PC with Windows-based Peaksimple program

Figure B.2. Diagram of Apparatus

Table B.2. Results of Experiment 2A

\begin{tabular}{||l|c|c||}
\hline Tracer & Methane & Difluoromethane \\
\hline$\%$ Tracer Recovered & $92 \%$ & $85 \%$ \\
\hline Retardation Factor & 1.00 & 1.52 \\
\hline Static K & 0 & 1.7 \\
\hline Water Saturation & N/A & 0.235 \\
\hline Mean Residence Time (hr) & 2.22 & 3.36 \\
\hline
\end{tabular}




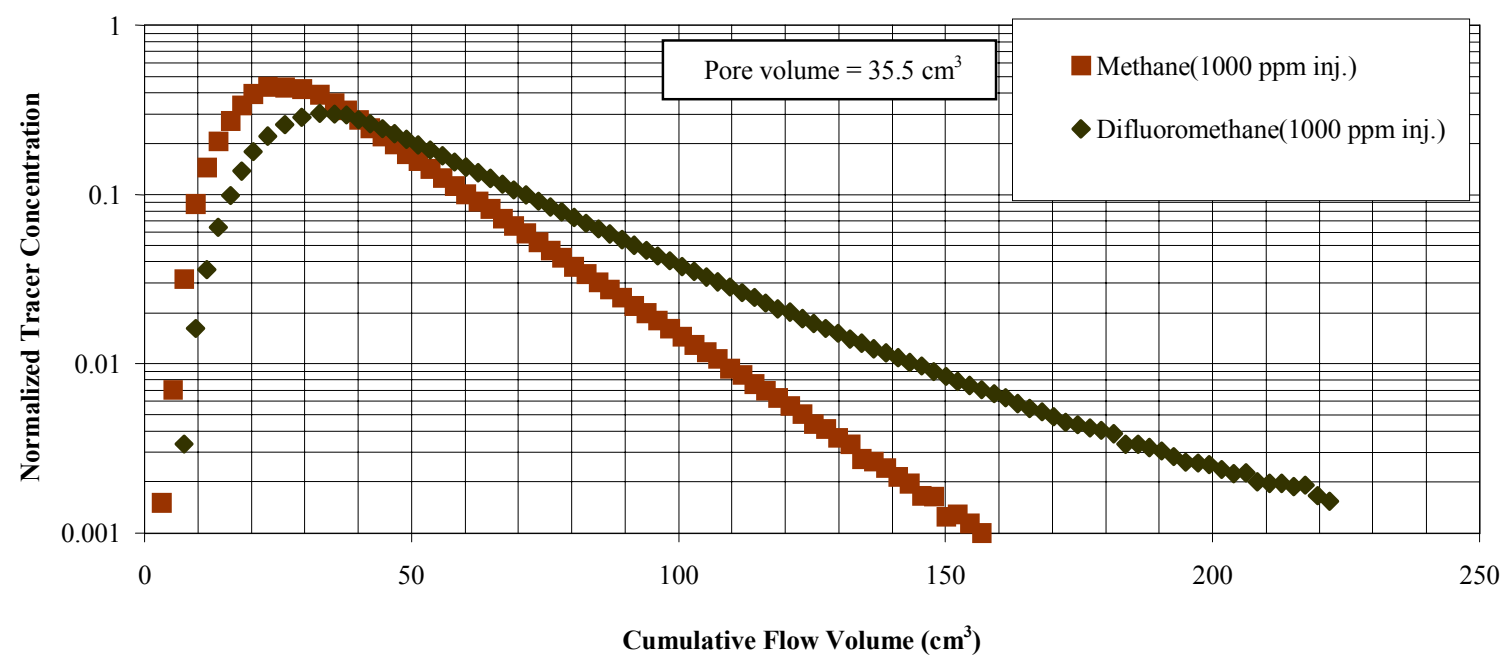

Figure B.3. PITT Tracer Response Curve for Experiment 2A

Experiment 2B used a flow rate of $0.70 \mathrm{~cm}^{3} / \mathrm{min}$, yielding a residence time of 1.10 hours. The results of tracer-elution analysis are summarized in Table B.3. The $S_{w}$ derived from first-moment analysis of the tracer response curves (Figure B.4) was 0.219, and the volumetrically determined $\mathrm{S}_{\mathrm{w}}$ was 0.238 .

Table B.3. Results of Experiment 2B

\begin{tabular}{|l|c|c||}
\hline Tracer & Methane & Difluoromethane \\
\hline$\%$ Tracer Recovered & $92 \%$ & $87 \%$ \\
\hline Retardation Factor & 1.00 & 1.48 \\
\hline Static K & 0 & 1.7 \\
\hline Water Saturation & N/A & 0.219 \\
\hline Mean Residence Time (h) & 0.74 & 1.10 \\
\hline
\end{tabular}



Figure B.4. PITT Tracer Response Curve for Experiment 2B 
Experiment $2 \mathrm{C}$ use flow rate of $2.33 \mathrm{~cm}^{3} / \mathrm{min}$, yielding a residence time of 0.28 hours. The results of tracer-elution analysis are summarized in Table B.4. The $\mathrm{S}_{\mathrm{w}}$ derived from first-moment analysis of the tracer response curves (Figure B.5) was 0.226, and volumetrically determined $\mathrm{S}_{\mathrm{w}}$ was 0.238 .

Table B.4. Results of Experiment 2C

\begin{tabular}{||l|c|c||}
\hline Tracer & Methane & Difluoromethane \\
\hline$\%$ Tracer Recovered & $92 \%$ & $119 \%$ \\
\hline Retardation Factor & 1.00 & 1.50 \\
\hline Static K & 0 & 1.7 \\
\hline Water Saturation & N/A & 0.226 \\
\hline Mean Residence Time (h) & 0.19 & 0.28 \\
\hline
\end{tabular}



Figure B.5. PITT Tracer Response Curve for Experiment 2C

An error analysis was performed on the tracer data (Table B.5). The percent errors in the water saturation were 5.56, 6.92, and 10.59 for experiments $2 \mathrm{~A}, 2 \mathrm{~B}$ and $2 \mathrm{C}$, respectively. The standard deviation of the partitioning coefficient for difluoromethane was 0.106 . The standard deviation of the retardation factors was $0.019,0.030$, and 0.061 for the three experiments, respectively.

Table B.5. Error Analysis for Experiments 2A, 2B, and 2C

\begin{tabular}{||l|c|c|c||}
\hline Tracer & $\mathbf{S}_{\mathbf{W}}$ & $\boldsymbol{\sigma}_{\mathbf{S w}}$ & \% error \\
\hline Difluoromethane (2A) & 0.235 & 0.013 & 5.56 \\
\hline Difluoromethane (2B) & 0.219 & 0.015 & 6.92 \\
\hline Difluoromethane (2C) & 0.226 & 0.024 & 10.59 \\
\hline
\end{tabular}


The Damkohler number (the dimensionless ratio of interphase mass transfer to advection) was calculated for each of these experiments to determine whether local equilibrium was achieved (Table B.6). According to the theoretical predictions of Deeds et al. (1999), the error in saturation estimates for large Damkohler numbers should be very small, which is consistent with the observations that the measured water saturations agree well with the mass balance measurement. These results show that, for the residence times used in these experiments, water saturations measured by a PITT are not affected by rate limited mass transfer provided the Damkohler number is large.

Table B.6. Damkholer Numbers for Experiments 2A, 2B, and 2C

\begin{tabular}{|c|c|c|}
\hline \hline Experiment & $\begin{array}{c}\text { Mean Residence Time } \\
\text { (hours) }\end{array}$ & Damkohler Number \\
\hline 2A & 3.36 & 9.06 \\
\hline 2B & 1.09 & 5.82 \\
\hline 2C & 0.35 & 3.74 \\
\hline
\end{tabular}

The final four experiments in this series used higher flow rates than the previous experiments to investigate the effect of smaller Damkholer numbers on $S_{\mathrm{w}}$ measurements. These experiments were carried out using a shorter chromatography column (5.08-cm inner diameter, 7.62-cm pack length) than was used in the previous experiments. The column was dry-packed with F-95 grade Ottawa sand (finer than the F-35 grade used previously) and brought to a residual water saturation of 0.270 by flooding and air flow. Volumetric measurement of the pore volume gave $54.2 \mathrm{~cm}^{3}$. A mass-balance estimate gave a pore volume of $53.8 \mathrm{~cm}^{3}$. The apparatus used for tracer injection and analysis was the same one used in the first series of experiments (see Figure B.2), with tracer slug sizes regulated by the $17.5-\mathrm{cm}^{3}$ injection loop. Tracer concentrations of $1000 \mathrm{ppm}$ methane and difluoromethane (in dry nitrogen carrier) were injected at a flow rates of $0.81 \mathrm{~cm}^{3} / \mathrm{min}, 1.24 \mathrm{~cm}^{3} / \mathrm{min}, 2.20 \mathrm{~cm}^{3} / \mathrm{min}$, and $3.83 \mathrm{~cm}^{3} / \mathrm{min}$.

Experiment $3 \mathrm{~A}$ used a flow rate of $0.81 \mathrm{~cm}^{3} / \mathrm{min}$, yielding a residence time of 1.33 hours. The results of tracer-elution analysis are summarized in Table B.7. The $\mathrm{S}_{\mathrm{w}}$ derived from first-moment analysis of the tracer response curves (Figure B.6) was 0.260, which compares well with the volumetrically determined $\mathrm{S}_{\mathrm{w}}$ of 0.270 .

Table B.7. Results of Experiment 3A

\begin{tabular}{|l|c|c||}
\hline Tracer & Methane & Difluoromethane \\
\hline$\%$ Tracer Recovered & $99 \%$ & $97 \%$ \\
\hline Retardation Factor & 1.00 & 1.60 \\
\hline Static K & 0 & 1.7 \\
\hline Water Saturation & N/A & 0.260 \\
\hline Mean Residence Time (h) & 0.83 & 1.33 \\
\hline
\end{tabular}




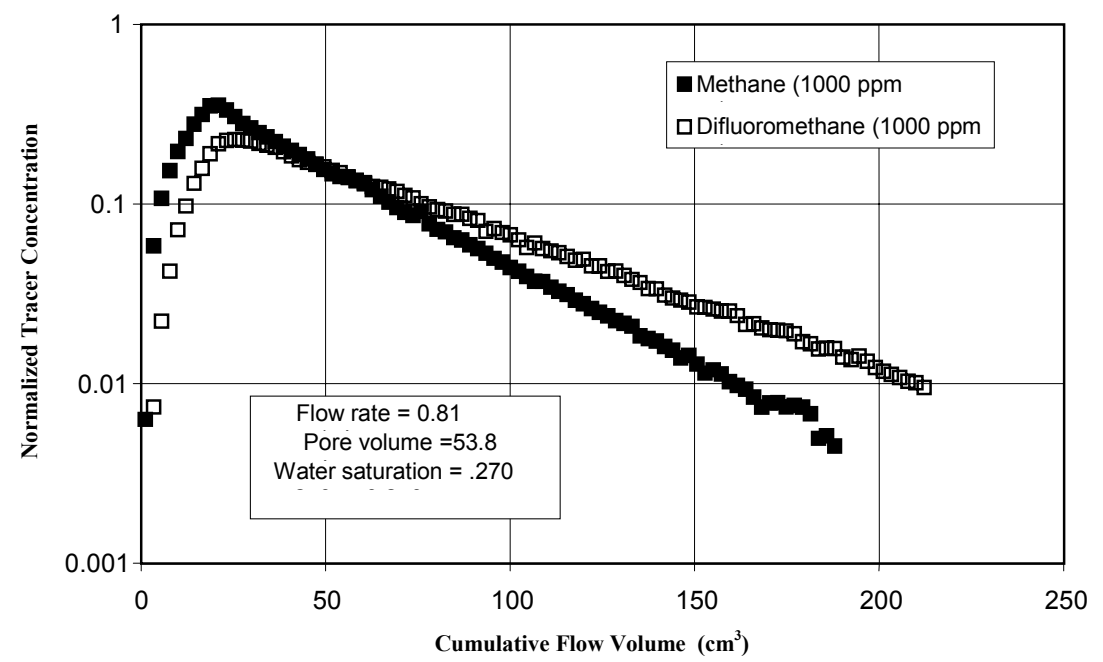

Figure B.6. PITT Tracer Response Curve for Experiment 3A

Experiment 3B used a flow rate of $1.24 \mathrm{~cm}^{3} / \mathrm{min}$, yielding a residence time of 0.86 hours. The results of tracer-elution analysis are summarized in Table B.8. The $\mathrm{S}_{\mathrm{w}}$ derived from first-moment analysis of the tracer response curves (Figure B.7) was 0.235, and volumetrically determined $\mathrm{S}_{\mathrm{w}}$ was 0.270 .

Table B.8. Results of Experiment 3B

\begin{tabular}{||l|c|c||}
\hline \hline Tracer & Methane & Difluoromethane \\
\hline \% Tracer Recovered & $101 \%$ & $106 \%$ \\
\hline Retardation Factor & 1.00 & 1.52 \\
\hline Static K & 0 & 1.7 \\
\hline Water Saturation & N/A & 0.235 \\
\hline Mean Residence Time (hr) & 0.56 & 0.86 \\
\hline
\end{tabular}

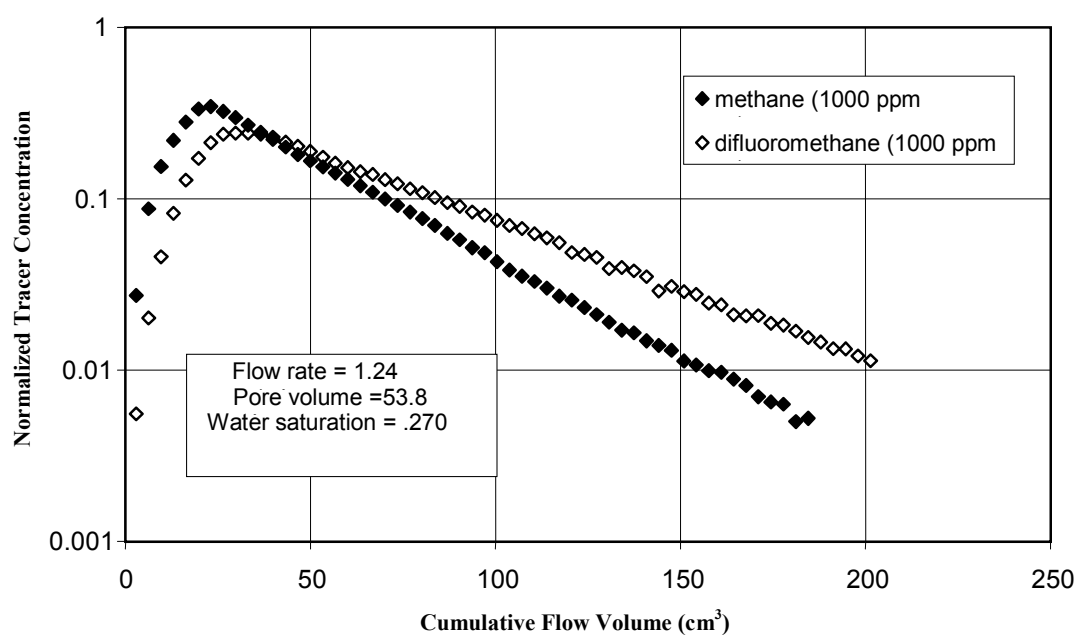

Figure B.7. PITT Tracer Response Curve for Experiment 3B 
Experiment $3 \mathrm{C}$ used a flow rate of $2.20 \mathrm{~cm}^{3} / \mathrm{min}$, yielding a residence time of 0.27 hours. The results of tracer-elution analysis are summarized in Table B.9. The $S_{w}$ derived from first-moment analysis of the tracer response curves (Figure B.8) was 0.235 (volumetrically determined $S_{w}$ was 0.270 ).

Table B.9. Results of Experiment 3C

\begin{tabular}{|l|l|l||}
\hline Tracer & Methane & Difluoromethane \\
\hline \% Tracer Recovered & $97 \%$ & $97 \%$ \\
\hline Retardation Factor & 1.00 & 1.59 \\
\hline Static K & 0 & 1.7 \\
\hline Water Saturation & N/A & 0.259 \\
\hline Mean Residence Time (h) & 0.31 & 0.50 \\
\hline
\end{tabular}

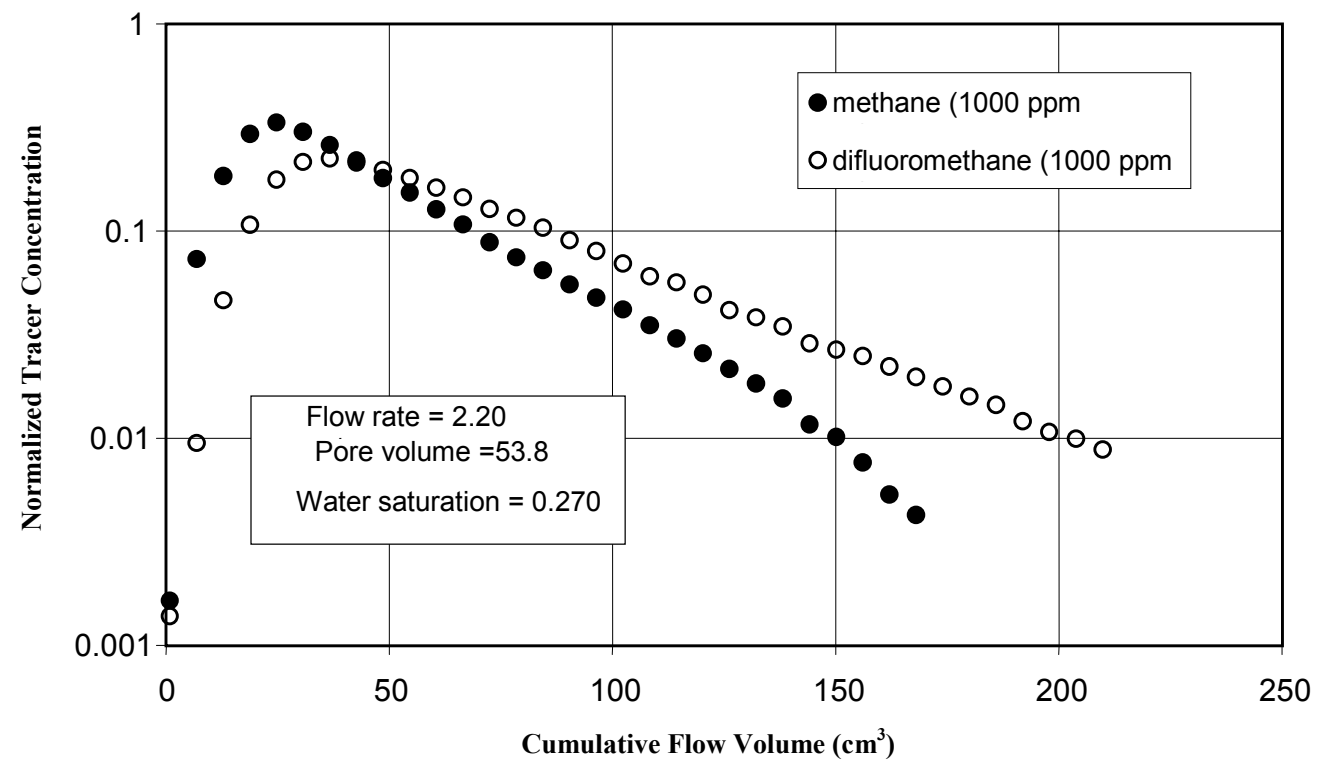

Figure B.8. PITT Tracer Response Curve for Experiment 3C

Experiment 3D used a flow rate of $3.83 \mathrm{~cm}^{3} / \mathrm{min}$, yielding a residence time of 0.7 hours. The results of tracer-elution analysis are summarized in Table B.10. The $\mathrm{S}_{\mathrm{w}}$ derived from first-moment analysis of the tracer response curves (Figure B.9) was 0.274, and volumetrically determined $\mathrm{S}_{\mathrm{w}}$ was 0.270 .

Table B.10. Results of Experiment 3D

\begin{tabular}{||l|c|c||}
\hline \hline Tracer & Methane & Difluoromethane \\
\hline$\%$ Tracer Recovered & $93 \%$ & $95 \%$ \\
\hline Retardation Factor & 1.00 & 1.64 \\
\hline Static K & 0 & 1.7 \\
\hline Water Saturation & N/A & 0.274 \\
\hline Mean Residence Time (h) & 0.16 & 0.27 \\
\hline
\end{tabular}




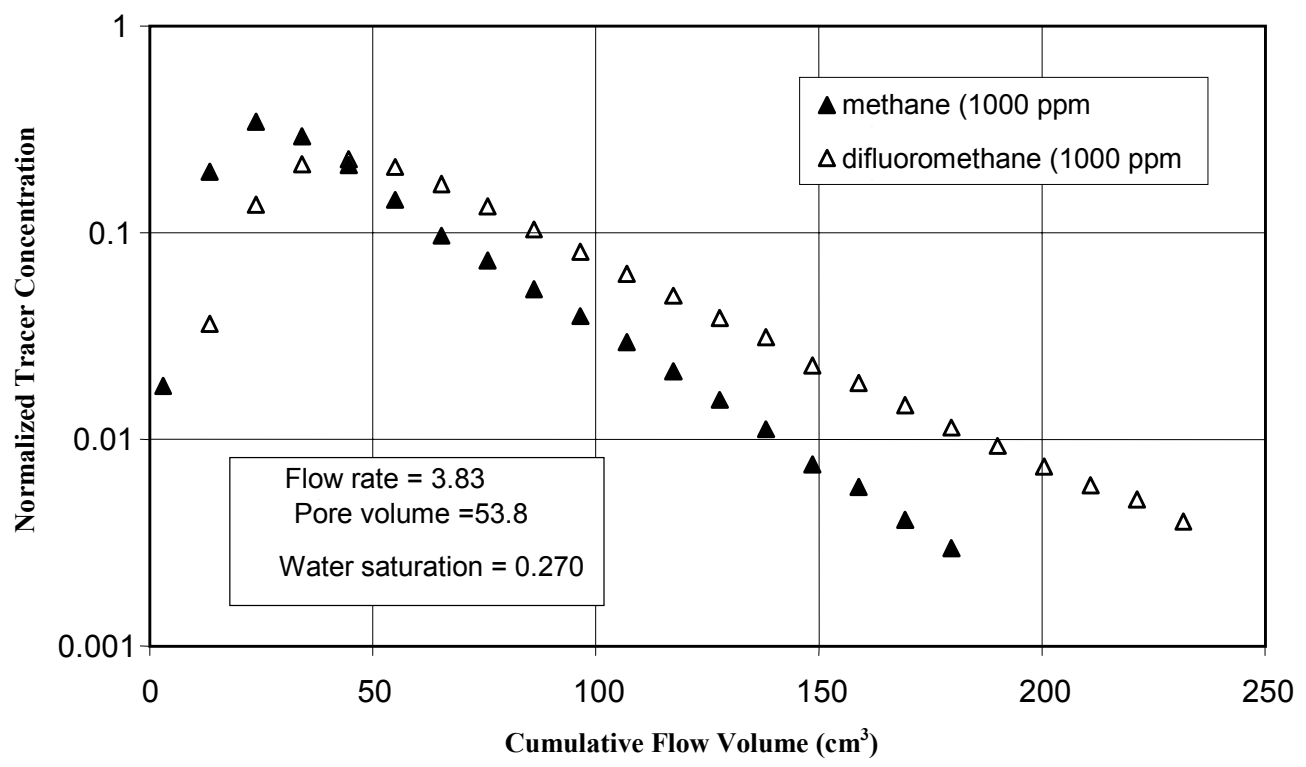

Figure B.9. PITT Tracer Response Curve for Experiment 3D

An error analysis (Table B.11) yielded percent errors in the water saturation of 5.83, 5.82, 5.38, and 4.91 for experiments $3 \mathrm{~A}, 3 \mathrm{~B}, 3 \mathrm{C}$, and $3 \mathrm{D}$, respectively. The standard deviation of the partitioning coefficient was 0.106 for difluoromethane. The standard deviation of the retardation factors was $0.029,0.023$, 0.022 , and 0.017 , respectively, for the four tests.

Table B.11. Error Analysis for Experiments 3A through 3D

\begin{tabular}{|l|c|c|c|}
\hline Tracer & $\mathbf{S}_{\mathbf{W}}$ & $\boldsymbol{\sigma}_{\mathbf{S w}}$ & \% error \\
\hline Difluoromethane (3A) & 0.260 & 0.015 & 5.83 \\
\hline Difluoromethane (3B) & 0.235 & 0.014 & 5.82 \\
\hline Difluoromethane (3C) & 0.259 & 0.014 & 5.38 \\
\hline Difluoromethane (3D) & 0.274 & 0.013 & 4.91 \\
\hline
\end{tabular}

The Damkohler numbers were lower than the previous series (Table B.12). The lowest Damkohler number was 1.21 with a mean tracer-residence time of 0.27 hours $(16.2 \mathrm{~min})$. Although the Damkohler numbers approached unity with very short residence times, the water saturation estimates from the tracers were accurate. These experiments agree with the conclusions of Deeds et al. (1999) that mass transfer effects at Damkohler numbers greater than unity do not impact the moment analysis, provided that the tracer-elution curve can be sufficiently captured. This means that the high advective flow rates envisaged for tank-leak detection PITTs will not adversely affect data analysis or results. 
Table B.12. Damkholer Numbers for Experiments 3A through 3D

\begin{tabular}{|c|c|c|}
\hline Experiment & $\begin{array}{c}\text { Mean residence time for } \\
\text { difluoromethane (hrs) }\end{array}$ & Damkohler number \\
\hline 3A & 1.33 & 2.19 \\
\hline 3B & 0.86 & 1.86 \\
\hline 3C & 0.50 & 1.50 \\
\hline 3D & 0.27 & 1.21 \\
\hline
\end{tabular}

\section{B.2 Tracer Partitioning Characteristics in Saline Solutions}

Fourteen experiments were performed at PNNL and two at UT-Austin investigating the effect of saline solutions on partitioning behavior. The first experiment at PNNL was to verify tracer partitioning behavior. This experiment also served as a shakedown for later experiments. A chromatography column (2.54-cm inner diameter, 47.0-cm pack length) was dry-packed with Hanford formation sand and brought to a residual water saturation of 0.409 by flooding and air flow. A mass-balance estimate of the pore volume gave $88.2 \mathrm{~cm}^{3}$. Tracer concentrations of $1000 \mathrm{ppmv}$ methane and chlorofluoromethane and $500 \mathrm{ppmv}$ of difluoromethane and pentafluoroethane (in dry nitrogen carrier) were injected at a flow rate of $2.0 \mathrm{~cm}^{3} / \mathrm{min}$. Results of tracer-elution analysis are summarized in Table B.13. The $\mathrm{S}_{\mathrm{w}}$ derived from first-moment analysis of the tracer response curves (Figure B.10) was 0.39, and the volumetrically determined $S_{w}$ was 0.41 . This experiment verified PNNL capabilities in tracer experimentation. The remaining 13 experiments characterized tracer partitioning behavior in ionic solutions (sodium thiosulfate and sodium nitrate). A summary of these experiments is presented in Table B.14.

Table B.13. Results of Preliminary PNNL Experiment

\begin{tabular}{||l|c|c|c|}
\hline \multicolumn{1}{|c|}{ Tracer } & Recovery & Static K & Sw \\
\hline Methane & $93 \%$ & 0 & N/A \\
\hline Difluoromethane & $96 \%$ & 1.72 & 0.38 \\
\hline Pentafluoroethane & $96 \%$ & 0.06 & N/A \\
\hline Chlorofluoromethane & $101 \%$ & 4.27 & 0.40 \\
\hline
\end{tabular}

The presence of $36 \mathrm{wt} \%$ sodium thiosulfate (as used in the demonstrations at the Mock Tank Site) reduced the difluoromethane dynamic $\mathrm{K}$ from 1.72 to 0.26 and the chlorofluoromethane dynamic $\mathrm{K}$ from 4.27 to 0.54 (Figure B.11). 




Figure B.10. PITT Tracer Response Curve for Preliminary PNNL Experiment

Two experiments were carried out at UT-Austin characterizing tracer partitioning behavior into saline solutions; the partitioning coefficient for difluoromethane decreased from 1.7 to only 0.25 when $40 \mathrm{wt} \%$ sodium thiosulfate was added to the water (Table B.15). The partitioning coefficient of dichloromethane in water was previously measured to be 10.7 . In the $40 \mathrm{wt} \%$ sodium thiosulfate solution, the partitioning coefficient was estimated to be 2.0 , but the value is considered only approximate because plastic tubing used in the test apparatus may have interfered with the elution of the tracer.

Table B.14. Summary of Saline-Solution Experiments at $\mathrm{PNNL}^{(\mathrm{a})}$

\begin{tabular}{|c|c|c|c|c|c|c|}
\hline PITT & Date & $\begin{array}{l}\text { Liquid } \\
\text { Phase }\end{array}$ & $\begin{array}{c}\text { Liquid } \\
\text { Density } \\
\left(\mathrm{gm} / \mathrm{cm}^{3}\right)\end{array}$ & Molarity & $\begin{array}{c}\text { K } \\
\text { Total } \\
\text { Difl Meth }\end{array}$ & $\begin{array}{c}\text { K } \\
\text { Total } \\
\text { ClFIMeth }\end{array}$ \\
\hline 1 & & Water & 0.997 & 0.000 & 1.78 & 4.27 \\
\hline 5 & $6 / 1 / 2001$ & $\mathrm{Na}_{2} \mathrm{~S}_{2} \mathrm{O}_{3}$ & 1.331 & 1.90 & 0.29 & 0.56 \\
\hline 6 & $6 / 5 / 2001$ & $\mathrm{Na}_{2} \mathrm{~S}_{2} \mathrm{O}_{3}$ & 1.331 & 1.90 & 0.23 & 0.52 \\
\hline 7 & $6 / 7 / 2001$ & $\mathrm{NaNO}_{3}$ & 1.03 & 0.696 & 1.65 & 4.40 \\
\hline 13 & $6 / 21 / 2001$ & $\mathrm{NaNO}_{3}$ & 1.05 & 1.035 & 1.30 & 3.43 \\
\hline 8 & $6 / 11 / 2001$ & $\mathrm{NaNO}_{3}$ & 1.07 & 1.39 & 1.07 & 2.89 \\
\hline 11 & $6 / 15 / 2001$ & $\mathrm{NaNO}_{3}$ & 1.11 & 2.09 & 1.03 & 2.64 \\
\hline 10 & $6 / 13 / 2001$ & $\mathrm{NaNO}_{3}$ & 1.18 & 3.48 & 0.93 & 2.35 \\
\hline 14 & $6 / 22 / 2001$ & $\mathrm{NaNO}_{4}$ & 1.26 & 5.22 & 0.66 & 1.57 \\
\hline 12 & $6 / 19 / 2001$ & $\mathrm{NaNO}_{3}$ & 1.35 & 6.96 & 0.40 & 0.85 \\
\hline
\end{tabular}

(a) Packing for all experiments was Hanford sand. 


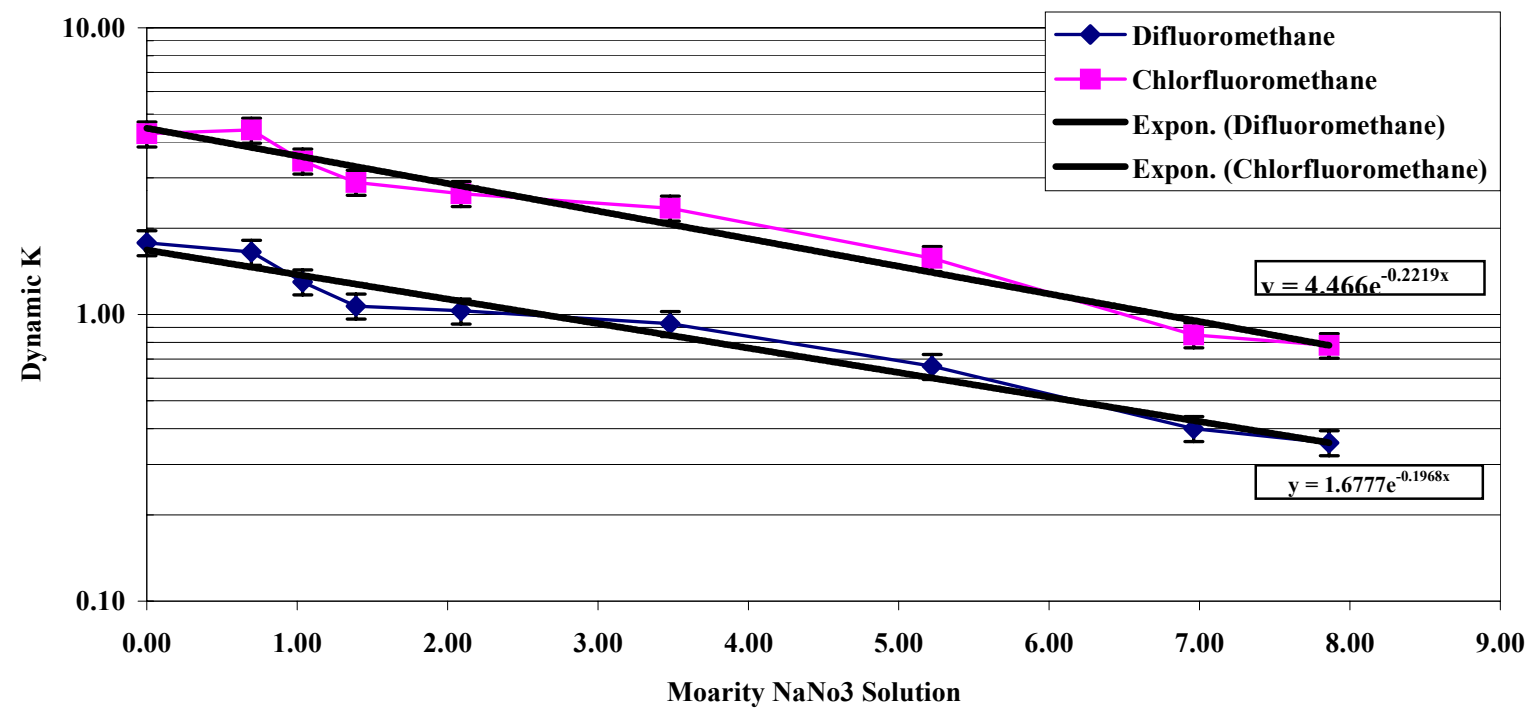

Figure B.11. Results of Saline-Solution Experiments at PNNL

Table B.15. Results of Saline-Solution Experiments at UT-Austin

\begin{tabular}{|l|c|c|c|c|}
\hline \multirow{2}{*}{} & \multicolumn{2}{|c|}{ Gas \#8 } & \multicolumn{2}{c|}{ Gas \#10 } \\
\cline { 2 - 5 } & $\mathbf{C H}_{\mathbf{4}}$ & $\mathbf{C H}_{\mathbf{2}} \mathbf{F}_{\mathbf{2}}$ & $\mathbf{C H}_{\mathbf{4}}$ & $\mathbf{C H}_{\mathbf{2}} \mathbf{C l}_{\mathbf{2}}$ \\
\hline \hline Mean residence volume (cc) & 32.2 & 35.3 & 32.4 & 56.3 \\
\hline Tracer recovered (\%) & 103 & 103 & 103 & 163 \\
\hline Retardation factor & 1 & 1.09 & 1 & 1.74 \\
\hline Water saturation & 0.27 & 0.27 & 0.27 & 0.27 \\
\hline Dynamic partitioning coefficient & - & 0.25 & - & 2.00 \\
\hline Mean residence time (hr) & 0.7 & 0.7 & 0.7 & 1.7 \\
\hline Flow rate (cc/min) & 0.79 & 0.79 & 0.79 & 0.55 \\
\hline
\end{tabular}

The observed lowering of partitioning coefficients in the presence of high-ionic-strength solutions such as tank waste will substantially reduce leak-detection sensitivity of the PITT methodology. Clearly, the issues related to non-equilibrium partitioning at high flow rates have been adequately addressed, but the decrease in partitioning coefficient at the high solute concentrations expected in Hanford tank wastes calls for reevaluation of tracer choice and revision of interwell-flowfield techniques to increase the PITT technology capability in the area of tank-leak quantification.

\section{Reference}

Deeds N, G Pope, and D McKinney. 1999. "Vadose Zone Characterization of a Contaminated Field Site Using Partitioning Interwell Tracer Technology.” Environmental Science and Tech Vol. 33, No. 16. 


\section{Appendix C}

Estimated Hydraulic and Pneumatic Conductivities for the Mock Tank Site Based on Geology, Lithology, and Grain-Size Analyses 


\section{Appendix C}

\section{Estimated Hydraulic and Pneumatic Conductivities for the Mock Tank Site Based on Geology, Lithology, and Grain-Size Analyses}

\section{C.1 Introduction}

Estimated hydraulic conductivity values for the Mock tank Site are given in this appendix based on grain-size analyses from 28 soil samples collected during the installation of cone penetrometer (CPT) borehole 8 (CPT 8) (see Figure 4.2 in the main report). The data were then used to estimate pneumatic conductivities. Pneumatic conductivities for the soil underlying the Mock Tank Site are needed for interpretation and performance assessment of the various Subsurface Air Flow and Extraction (SAFE) technologies.

\section{C.2 Background}

Much research has been done on the relationship of porous media and hydraulic conductivity. The United States Geological Survey (USGS) and other researchers have made very concerted efforts to correlate hydrologic properties of various sedimentary media to grain-size distribution. Their work has given some reasonably reliable approximations of hydraulic conductivities based on sieve data. The results from various aquifers, which are mostly in the western United States, demonstrate that the ability to accurately predict hydraulic properties from material grain-size distributions depends on the specific lithology, stratigraphy, and location. Site-specific conditions have intrinsic and unique lithologic (skewness, roundness, kurtosis, mineralogy) and depositional (consolidation, cementation) characteristics.

At Hanford, the quality of the grain-size data depends largely on the drilling method used. Samples collected by methods that are faster and inexpensive may produce more fines because of the grinding and pulverizing action of the drill bit. Alternatively, methods that better preserve the original grain-size distribution can be costly and time consuming.

\section{C.3 Geology of the Hanford Formation}

All of the CPT samples for this effort are from the Hanford formation, which is the informal name given to all glaciofluvial strata deposited from cataclysmic ice-age floods within the Pasco Basin (DOE 1988). The Hanford formation consists predominantly of unconsolidated sediments that cover a wide range in grain size, from pebble- to boulder-gravel, fine- to coarse-grained sand, silty sand, and silt. The Hanford formation is further subdivided into gravel- (H1), sand- (H2), and silt-dominated facies, which transition into one another laterally with distance from the main, high-energy, flood currents (Wood et al. 2000).

The sand and gravel fractions of the Hanford formation average about 50\% mafic (basalt) and 50\% felsic material (Tallman et al. 1979). The felsic component comprises quartz and feldspar with some samples containing greater than 10 percent pyroxene, amphibole, mica, chlorite, ilmenite, and magnetite. 
The silt- and clay-sized fractions consist of quartz, feldspar, mica, and smectite. This mineral assemblage gives the Hanford formation its characteristic "salt and pepper" appearance, often noted in drillers' and geologists' logs.

\section{C.4 Grouping and Matching of Grain-Size Distributions}

Grain-size distributions for the 28 samples at the Mock Tank Site were compared with similar grainsize distributions of known hydraulic conductivity for the Hanford formation sediments published by Khaleel and Freeman (1995). The samples, which were collected at 1-ft intervals from 7 to $35 \mathrm{ft}$ below ground surface (bgs), were grouped based on texture. Khaleel and Freeman (1995) considered four primary particle sizes:

- 10 U.S. sieve size (>2 mm [0.08 in.]) by USDA, Wentworth/USGS, AASHO scales; these are considered gravel.

- 10 to 60 U.S. sieve size (2 to $0.25 \mathrm{~mm}$ [0.08 to $0.01 \mathrm{in}$.]) by USDA, Wentworth/USGS, AASHO scales; these are considered coarse to medium sand.

- 60 to 200 U.S. sieve size ( 0.25 to $0.074 \mathrm{~mm}$ [0.01 to 0.002 in.]) by Wentworth/USGS, AASHO scales; these are considered fine sand.

- <200 U.S. sieve size (0.074 mm [0.01 in.]) by Wentworth/USGS, AASHO scales; these are considered silt and clay.

Only the four particle size categories (gravel, coarse to medium sand, fine sand, and silt/clay) were used to develop groups of similar grain-size distributions. Similar means that each sample contained a comparable percentage of each of the four categories. Once assigned to a common group, a similar (approximately matching) Hanford grain-size distribution was found in Khaleel and Freeman (1995). The hydraulic conductivity for that distribution from the nearest well listed was then assigned to that group of samples. The three groups of samples identified and their corresponding estimated hydraulic conductivities are shown in Table C.1.

Table C.1. Assignment of Hydraulic Conductivity Values

\begin{tabular}{|l|c|c|}
\hline \multicolumn{1}{|c|}{ Group } & $\begin{array}{c}\text { Hydraulic Conductivity } \\
(\mathbf{c m} / \mathbf{s})\end{array}$ & $\begin{array}{c}\text { Pneumatic Conductivity } \\
\mathbf{( c m / s )}\end{array}$ \\
\hline Sandy gravel & $1.8 \times 10^{-5}$ & $2.0 \times 10^{-6}$ \\
\hline Silty Sand & $2.8 \times 10^{-4}$ & $3.1 \times 10^{-5}$ \\
\hline Sand & $8.7 \times 10^{-4}$ & $9.6 \times 10^{-5}$ \\
\hline
\end{tabular}

\section{C.5 Pneumatic Conductivities}

Intrinsic permeability values (a function only of the porous medium of interest) are derived from hydraulic conductivities using water density and dynamic viscosity values. Pneumatic conductivities are then derived from the intrinsic permeability values using density and dynamic viscosity values for air 
(Table C.1). Standard conditions for property calculations are $293 \mathrm{~K}\left(20^{\circ} \mathrm{C}\right)$ for water, $294 \mathrm{~K}\left(21.1^{\circ} \mathrm{C}\right.$ or $\left.70^{\circ} \mathrm{F}\right)$ and $101.325 \mathrm{kPa}(1.0 \mathrm{~atm})$ pressure for air.

\section{C.6 References}

DOE. 1988. Consultation Draft, Site Characterization Plan, Reference Repository Location, Hanford Site, Washington. DOE-RW-0164, U.S. Department of Energy, Office of Civilian Radioactive Waste Management, Vol. 1, Washington, DC.

Khaleel R and EJ Freeman. 1995. Variability and Scaling of Hydraulic Properties for 200 Area Soils, Hanford Site. WHC-EP-0883, Westinghouse Hanford Company, Richland, Washington.

Tallman AM, KR Fecht, MC Marratt, and GV Last. 1979. Geology of the Separations Areas, Hanford Site, South-Central Washington. RHO-ST-23, Rockwell Hanford Operations, Richland, Washington.

Wood MI, R Schalla, BN Bjornstad, and SM Narbutovskih. 2000. Subsurface Conditions Description of the B-BX-BY Waste Management Area. HNF-5507 Rev. 0, CH2M HILL Hanford Group, Inc., Richland, Washington. 


\title{
Appendix D
}

\section{Supplemental Partitioning Tracer Data}

\author{
from the Mock Tank Structure
}




\section{Appendix D}

\section{Supplemental Partitioning Tracer Data from the Mock Tank Structure}

This document contains supplemental graphs of the partitioning tracer data collected by the field gas chromatograph (GC). The graphs show injected tracer behavior, normalized to the injected concentration and measured in hours from time of injection. They are arranged by individual partitioning interwell tracer test (PITT) (PITT-2, PITT-3, and PITT-5) conducted at the Mock Tank Structure for each of three screened intervals used by the subsurface air flowfield (10 to $20 \mathrm{ft} \mathrm{bgs,} 20$ to $30 \mathrm{ft}$ bgs, 30 to $40 \mathrm{ft}$ bgs) (Figures D.1 to D.9).

Within each graph there are four data sets showing the two tracers and the two well sets from which the data were collected. The data from the extraction wells are in blue, and the data from the monitoring wells (with a much lower flowrate of air) are in red. The conservative tracer (methane) is the darker shaded line, and the partitioning tracer (chlorofluoromethane) is the lighter shaded line in both the monitoring and extraction wells (red and blue, respectively).

Figure D.3 (PITT-2) demonstrates the desired partitioning behavior of the chlorofluoromethane tracer versus the conservative tracer, methane, with delayed elution visible in both the monitoring and extraction wells. A distinct peak is present for both compounds in both well sets with the respective peaks arriving at the same time (conservative tracer arrived first and partitioning tracer second in both wells). This indicates an undisturbed flowpath at this depth when the test took place. The highly altered elution present in the shallower depths beneath the Mock Tank Structure (Figures D.1 and D.2) confirm that a leak has occurred during this test.

Figure D.10 shows the tracer elution curves from extraction well 2030E during PITT-6. For this application of the partitioning tracer method, a different tracer injection protocol was used. First, the advective flowfield was established, and then the air injection was shut off for 30 minutes while the tracers were injected. This allowed the tracers to be introduced into the subsurface such that they were all in the direct flow lines toward the extraction wells due to the vacuum influence of the extraction process. This was in contrast to the way in which the tracers had been injected in each previous partitioning tracer test. The previous protocol resulted in tracer being pushed into the subsurface in 360 degrees, causing some tracer to take a very long flowpath to the extraction well and thus creating long tailings. Smoother tracer curves are noted in Figure D.10 than those produced during the other partitioning tracer tests. However, because this test was conducted following the primary TLDD activities, the data from PITT-6 were not analyzed. This PITT demonstration was an example of the kind of development activities that are needed to adopt the partitioning tracer method for leak detection and monitoring. 


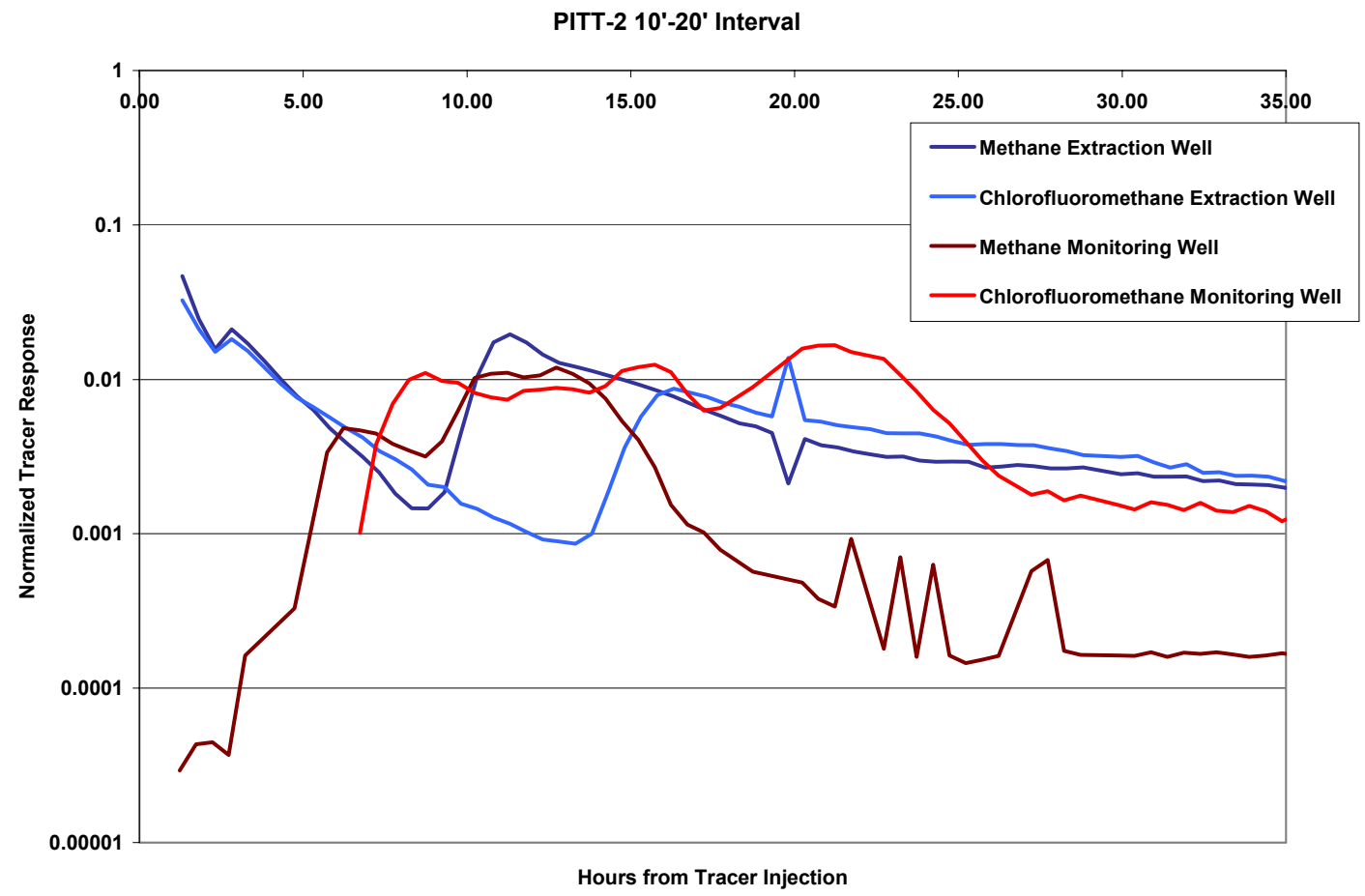

Figure D.1. PITT-2, 10 to $20 \mathrm{ft}$ bgs Screened Interval

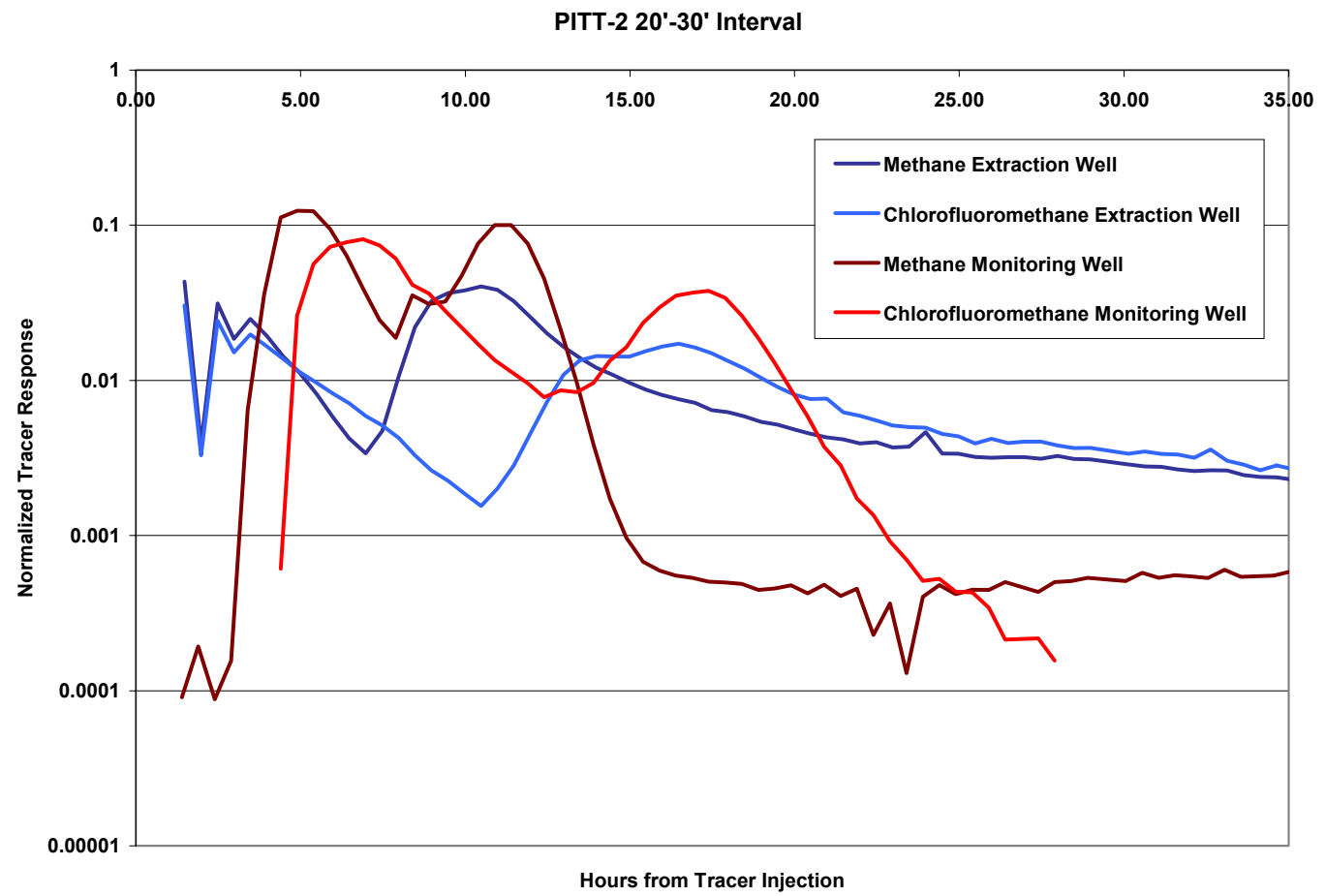

Figure D.2. PITT-2, 20 to $30 \mathrm{ft}$ bgs Screened Interval 
PITT-2 30'-40' Interval

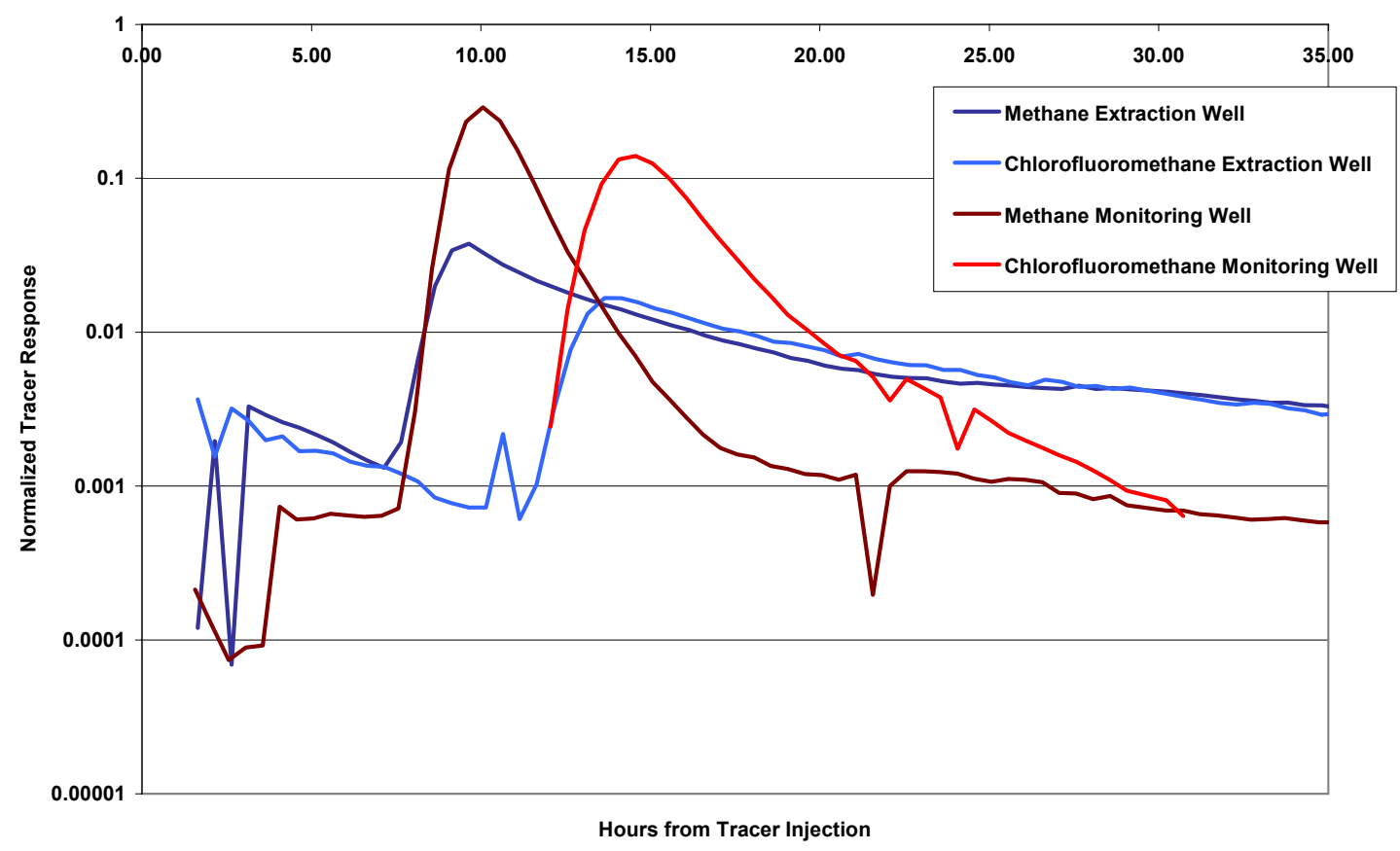

Figure D.3. PITT-2, 30 to $40 \mathrm{ft}$ bgs Screened Interval

PITT-3 10'-20' Interval

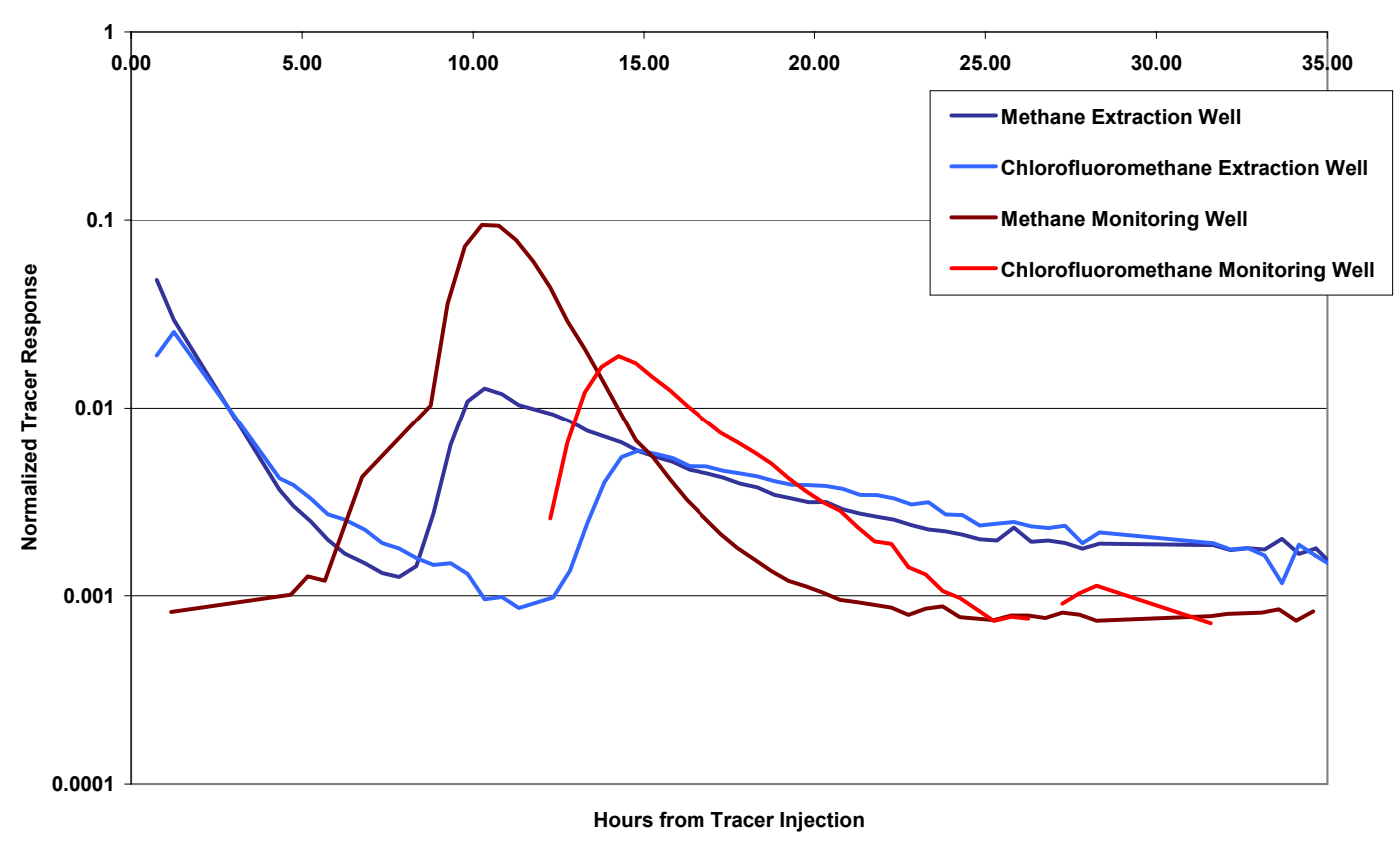

Figure D.4. PITT-3, 10 to $20 \mathrm{ft}$ bgs Screened Interval 


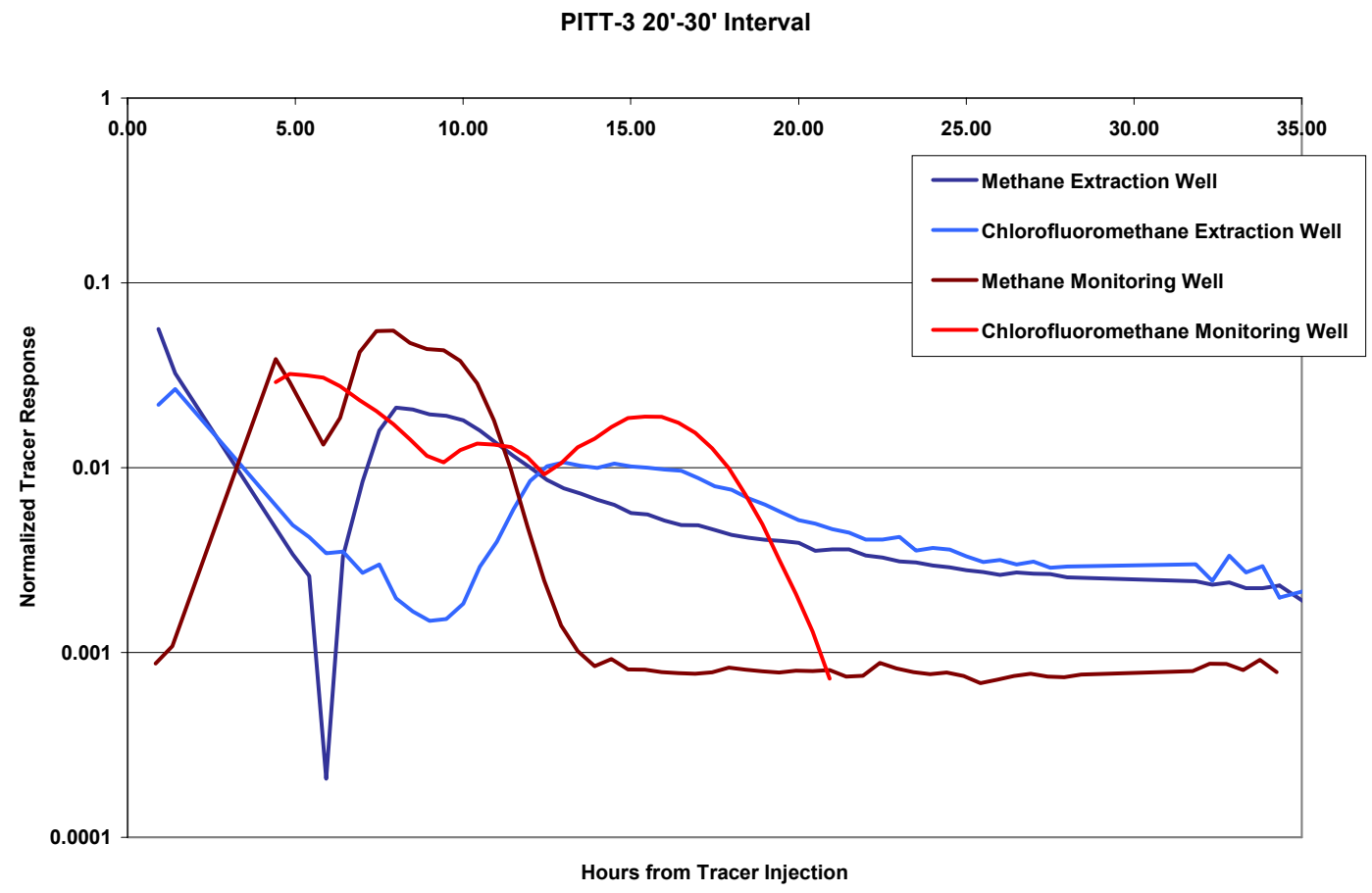

Figure D.5. PITT-3, 20 to $30 \mathrm{ft}$ bgs Screened Interval

PITT-3 30'-40' Interval

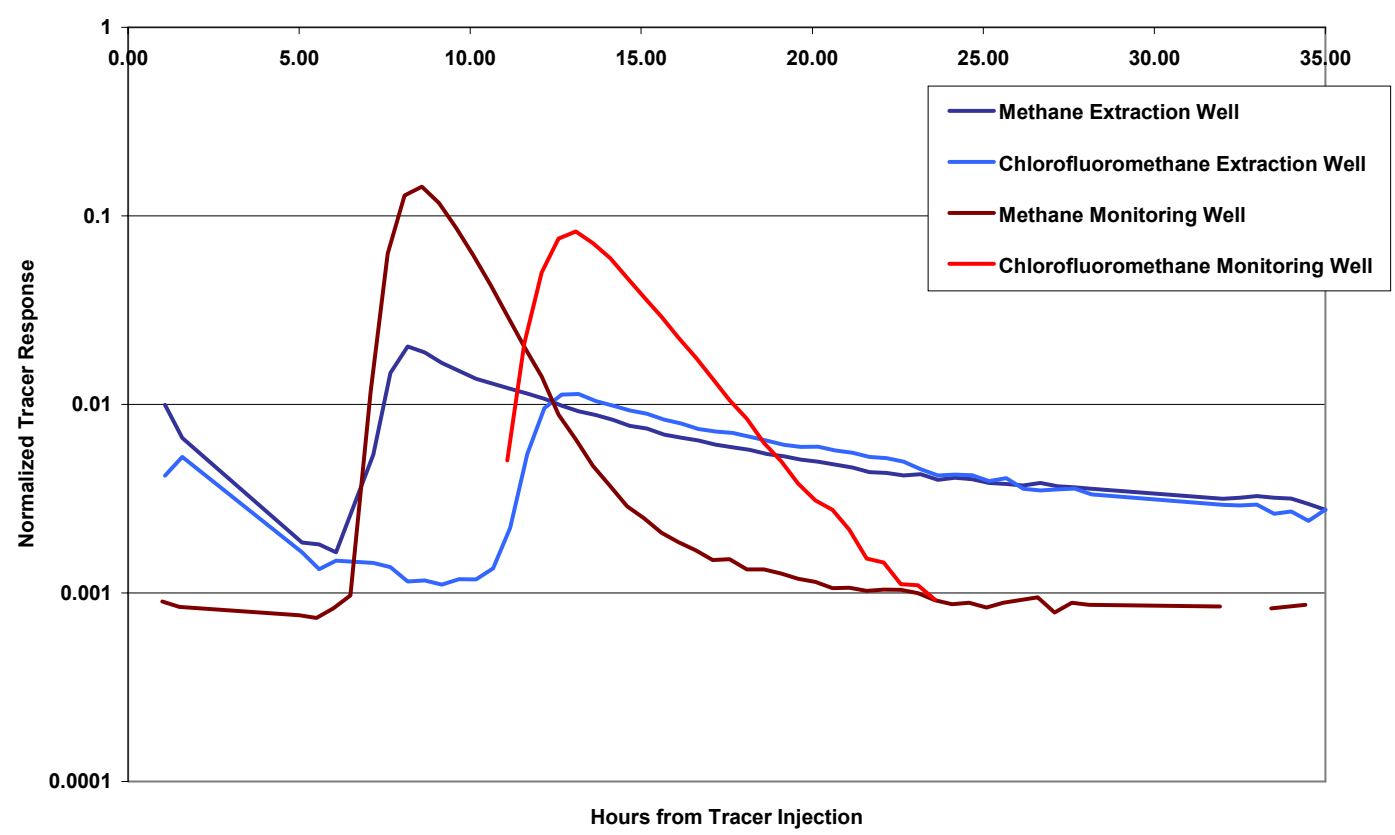

Figure D.6. PITT-3, 30 to $40 \mathrm{ft}$ bgs Screened Interval 


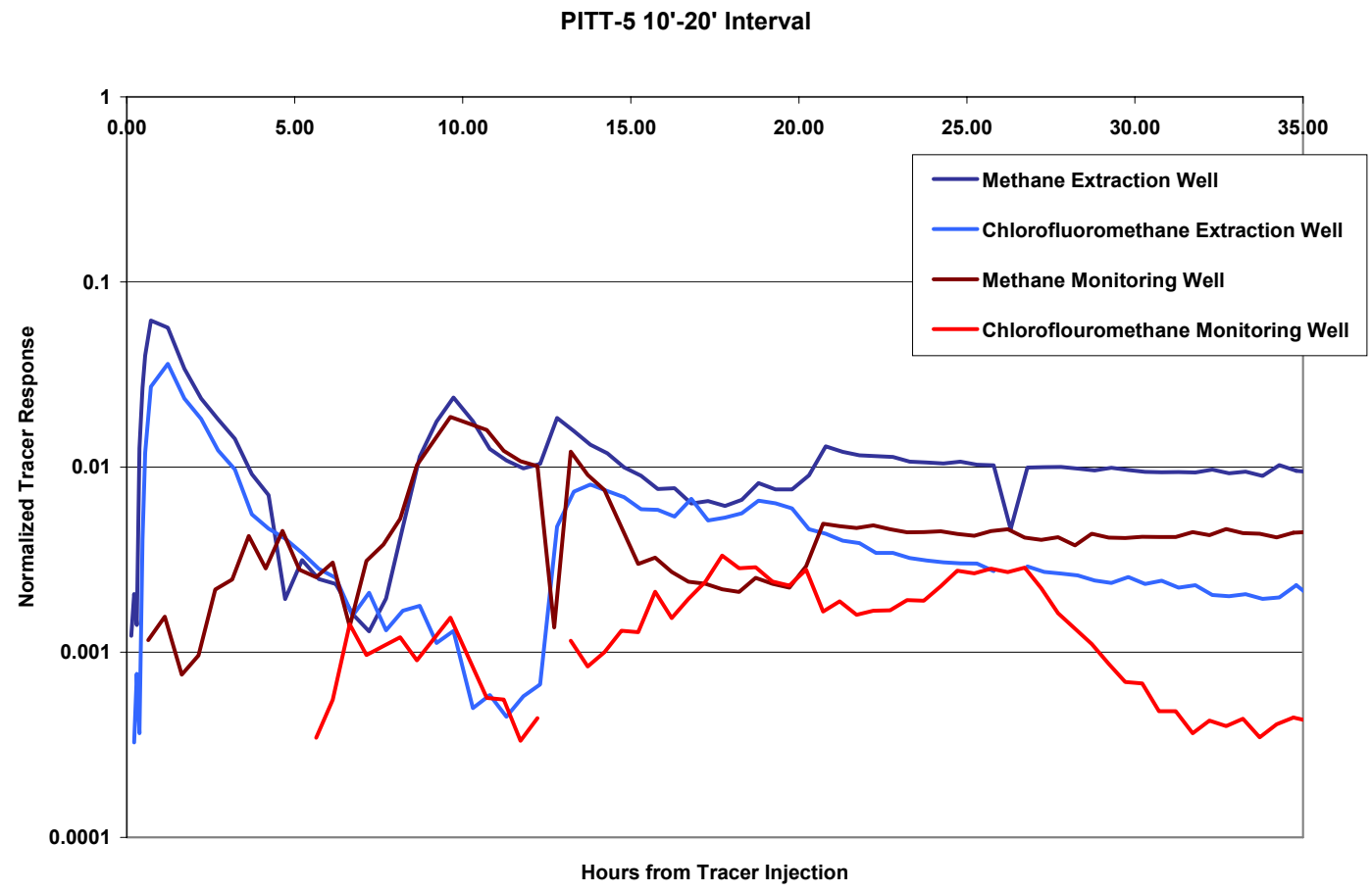

Figure D.7. PITT-5, 10 to $20 \mathrm{ft}$ bgs Screened Interval

PITT-5 20'-30' Interval

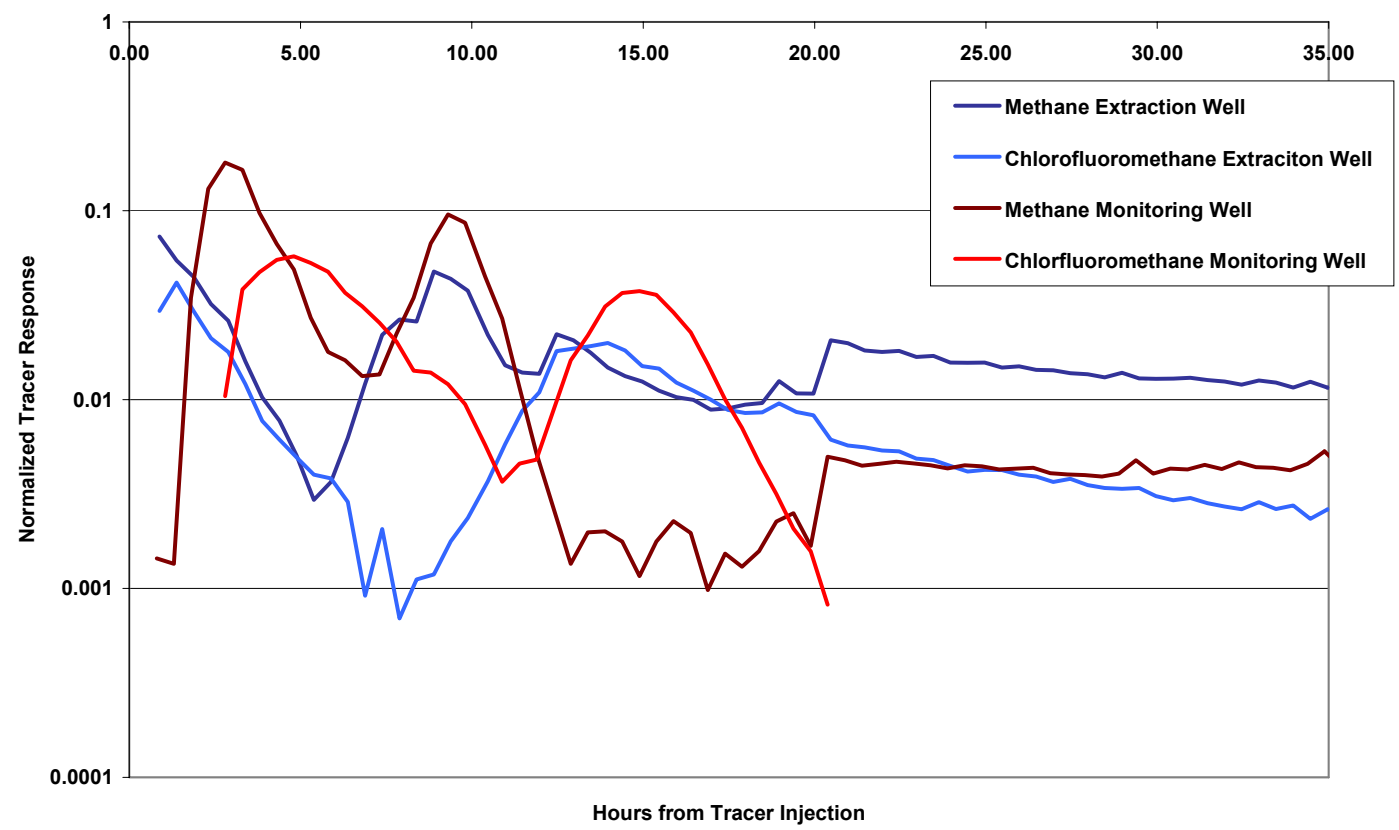

Figure D.8. PITT-5, 20 to $30 \mathrm{ft}$ bgs Screened Interval 


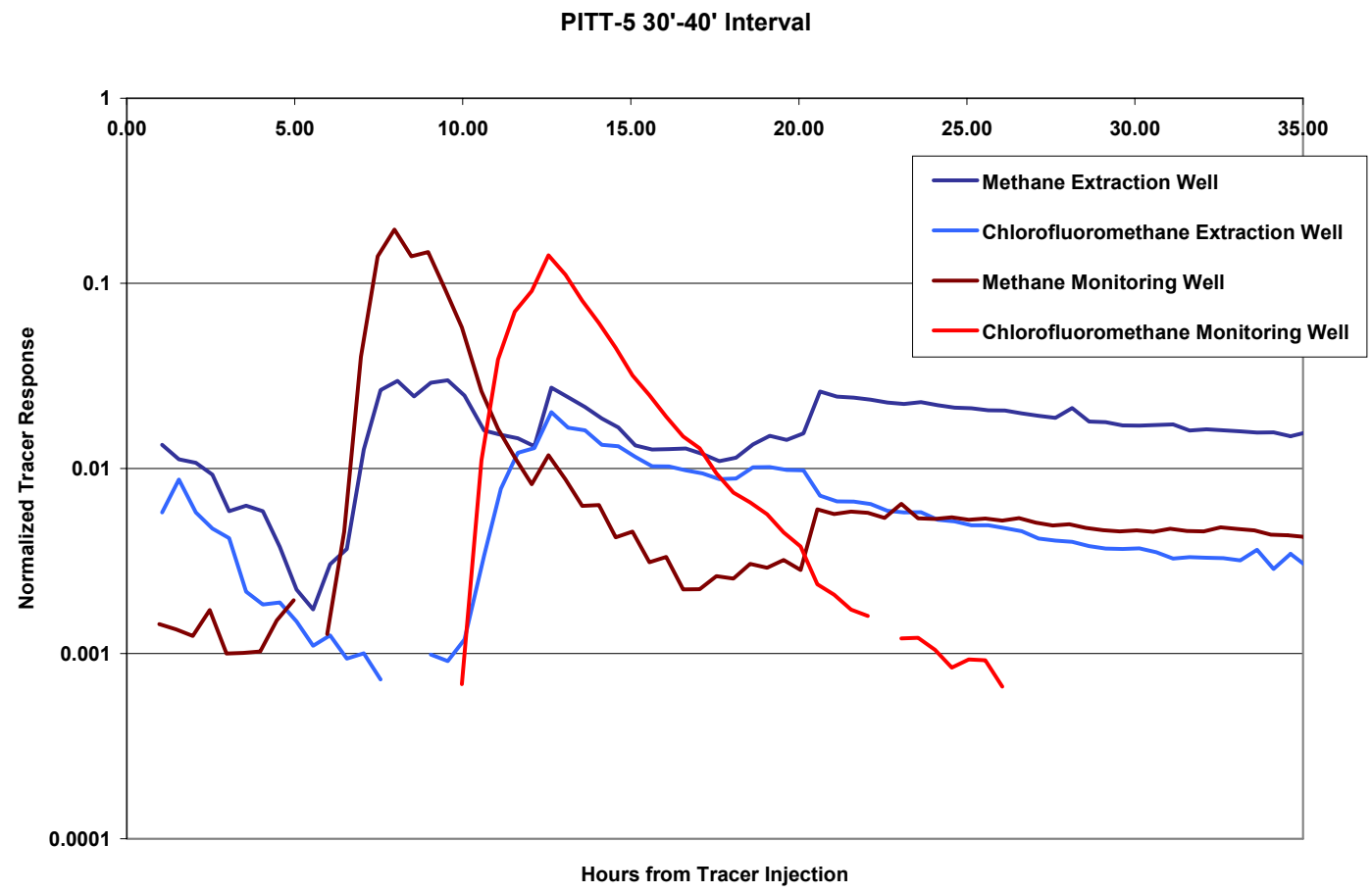

Figure D.9. PITT-5, 30 to $40 \mathrm{ft}$ bgs Screened Interval

PITT-6 20'-30' Interval

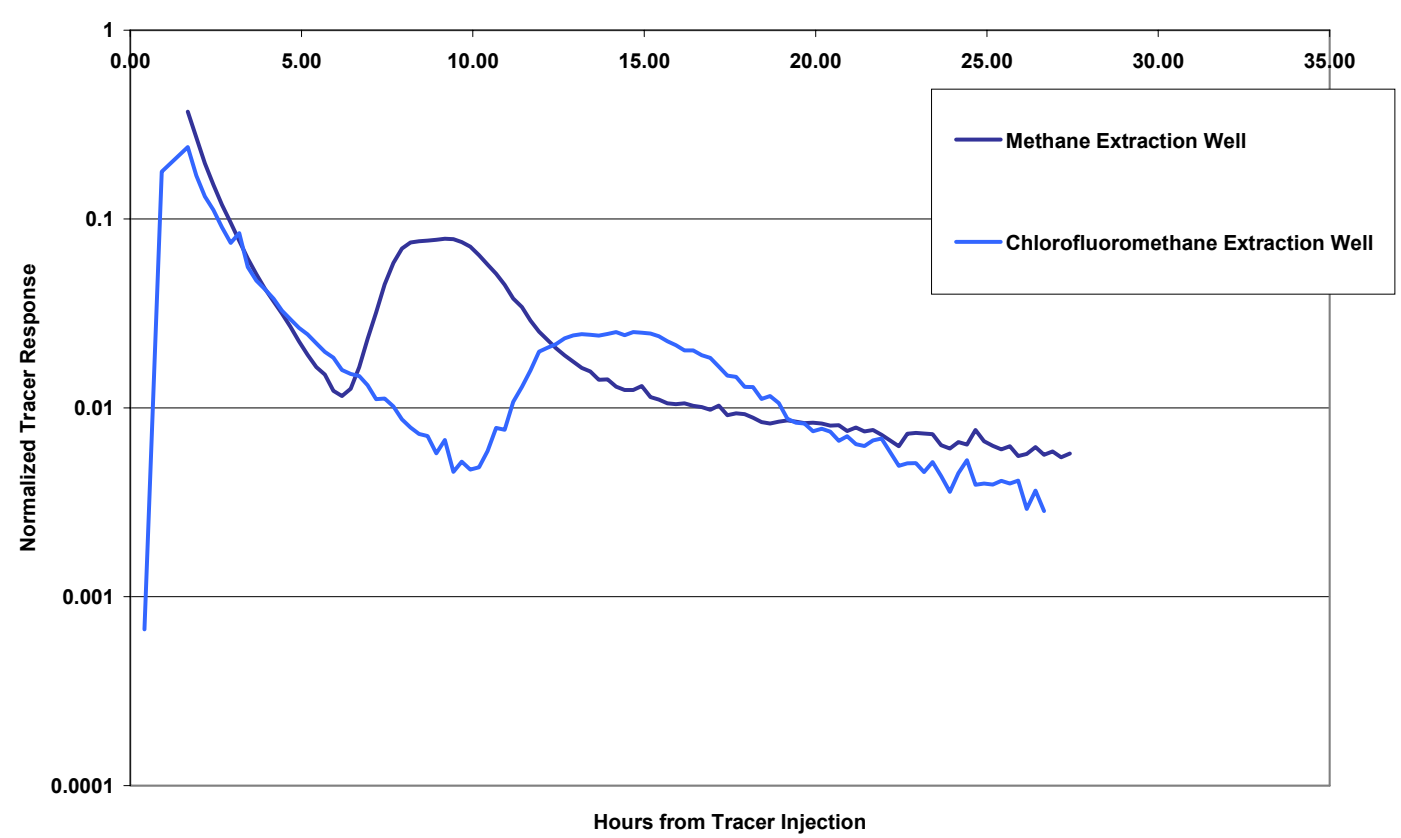

Figure D.10. PITT-6, 20 to $30 \mathrm{ft}$ bgs Screened Interval 
Appendix E

Complementary SAFE Technologies 


\section{Appendix E}

\section{Complementary SAFE Technologies}

This appendix provides descriptions of the complementary Subsurface Air Flow and Extraction (SAFE) technologies conceived during the course of this project. These technologies were discussed briefly in Section 6 of the main report. As with the four primary technologies tested in FY 2001 (in-tank tracers, flowfield disturbance, partitioning tracer method, and soil desiccation), these technologies are unique in concept but share a common subsurface flowfield (Figure E.1). Their potential applicability to leak detection, monitoring, and mitigation (LDMM) for retrieval operations at the single-shell tanks (SSTs) is summarized in Table E.1. These technologies are less mature than the other four and will require significantly more development before field-testing or deployment.

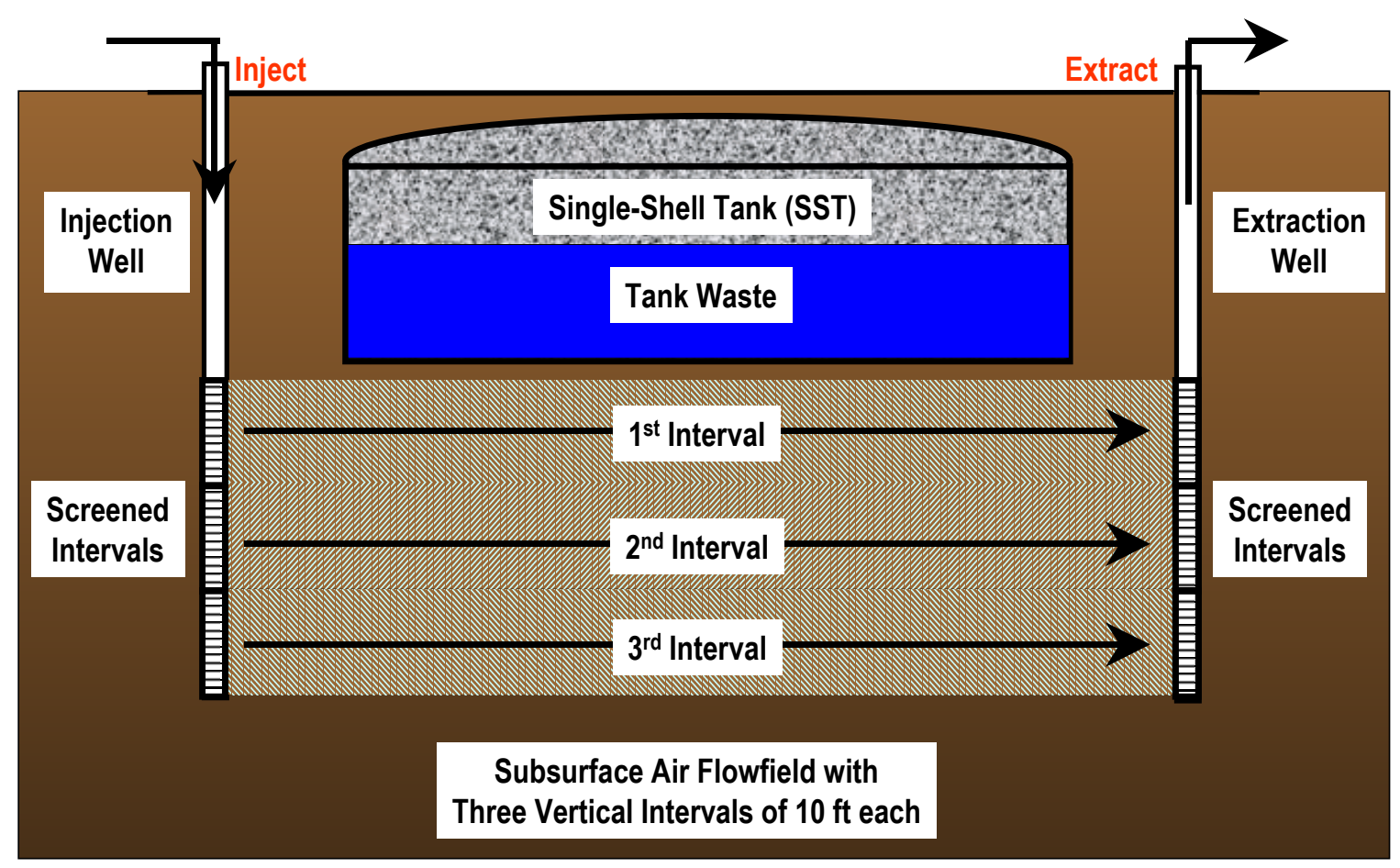

Figure E.1. Subsurface Air Flow and Extraction (SAFE) 
Table E.1. Complementary SAFE Technologies

\begin{tabular}{|c|c|c|c|c|c|c|c|c|}
\hline \multirow[b]{2}{*}{ Technology } & \multirow[b]{2}{*}{ Description } & \multicolumn{4}{|c|}{ Applicability } & \multirow[b]{2}{*}{ Testing Status } & \multirow[b]{2}{*}{ Needs } & \multirow[b]{2}{*}{ Comments } \\
\hline & & ڤ艹 & 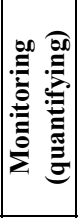 &  & 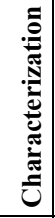 & & & \\
\hline $\begin{array}{l}\text { Radon } \\
\text { Displacement }\end{array}$ & $\begin{array}{l}\text { Detection of increased } \\
\text { concentrations of radon gas } \\
\text { in effluent well(s) as leak } \\
\text { liquid displaces radon from } \\
\text { soil }\end{array}$ & $\mathrm{X}$ & & & & $\begin{array}{l}\text { Concept only; could be very } \\
\text { inexpensive method for leak } \\
\text { detection; would require } \\
\text { establishing background levels } \\
\text { and fluctuations }\end{array}$ & $\begin{array}{l}\text { Could be tested at Mock } \\
\text { Tank Site }\end{array}$ & $\begin{array}{l}\text { Equipment for test is } \\
\text { on hand }\end{array}$ \\
\hline $\begin{array}{l}\text { Tank Waste } \\
\text { Vapors }\end{array}$ & $\begin{array}{l}\text { Potential candidate for leak } \\
\text { detection because ammonia } \\
\text { exists in most of the tanks; } \\
\text { butanol and acetone may be } \\
\text { applicable as well; detection } \\
\text { of radioactive gases such as } \\
\text { xenon and radon emanating } \\
\text { either from tank waste or } \\
\text { from in-tank tracers }\end{array}$ & $\mathrm{X}$ & & & & $\begin{array}{l}\text { Preliminary investigation; } \\
\text { possible in-tank radiotracers } \\
\text { identified }\end{array}$ & $\begin{array}{l}\text { Detection requires } \\
\text { specialized equipment; } \\
\text { column and box } \\
\text { experiments proposed }\end{array}$ & $\begin{array}{l}\text { Detection is } \\
\text { complicated by } \\
\text { subsurface transport } \\
\text { issues }\end{array}$ \\
\hline $\begin{array}{l}\text { Reactive } \\
\text { Tracers }\end{array}$ & $\begin{array}{l}\text { Use of tracers that react with } \\
\text { the tank waste for leak } \\
\text { detection and monitoring }\end{array}$ & $\mathrm{X}$ & $\mathrm{X}$ & & & $\begin{array}{l}\text { Testing using carbon dioxide } \\
\text { underway, tracer strongly } \\
\text { absorbing on Hanford soils }\end{array}$ & $\begin{array}{l}\text { Testing using hydrogen } \\
\text { sulfide proposed }\end{array}$ & $\begin{array}{l}\text { Both single and } \\
\text { binary reactive tracers } \\
\text { under preliminary } \\
\text { investigation }\end{array}$ \\
\hline $\begin{array}{l}\text { In Situ Gaseous } \\
\text { Reduction }\end{array}$ & $\begin{array}{l}\text { Use of chemically reactive } \\
\text { gas mixtures to reduce and } \\
\text { immobilize contaminants }\end{array}$ & & & $\mathrm{X}$ & & $\begin{array}{l}\text { Lab and field studies } \\
\text { conducted for chromium; lab } \\
\text { studies under way for } \\
\text { technetium }\end{array}$ & $\begin{array}{l}\text { Field test for technetium } \\
\text { reduction to demonstrate } \\
\text { effectiveness }\end{array}$ & \\
\hline $\begin{array}{l}\text { Interfacial } \\
\text { Tracers }\end{array}$ & & & & & $\mathrm{X}$ & Tested in other applications & $\begin{array}{l}\text { Lab and field studies } \\
\text { needed to develop } \\
\text { technology for LDMM } \\
\text { application }\end{array}$ & \\
\hline
\end{tabular}

\section{E.1 Radon Displacement}

Naturally occurring radon in the subsurface becomes displaced by an aqueous influx (Figure E.2). Radon emanation rates in most soils are increased by more than an order of magnitude as a result of complete saturation with water. Concentrated brine should enhance the effect considerably. The presence of a radon spike in the extracted air would indicate a tank leak. As such, radon displacement is a potential candidate for leak detection.

\section{E.2 Tank Waste Vapors}

Detection of trace radioactive gases or volatile tank waste vapors in the extracted air is a potential candidate technology for leak detection (Figure E.3). 


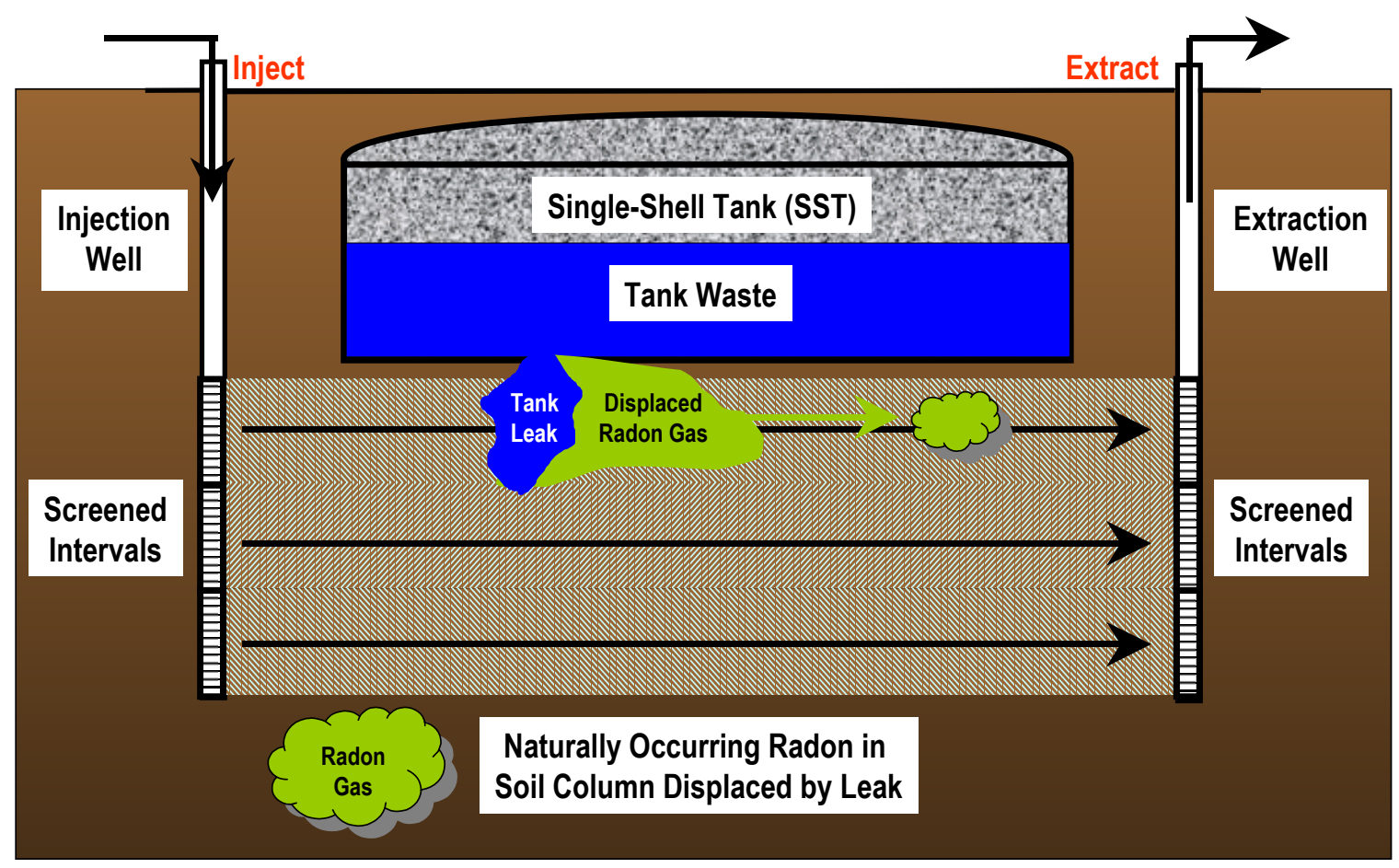

Figure E.2. Radon Displacement

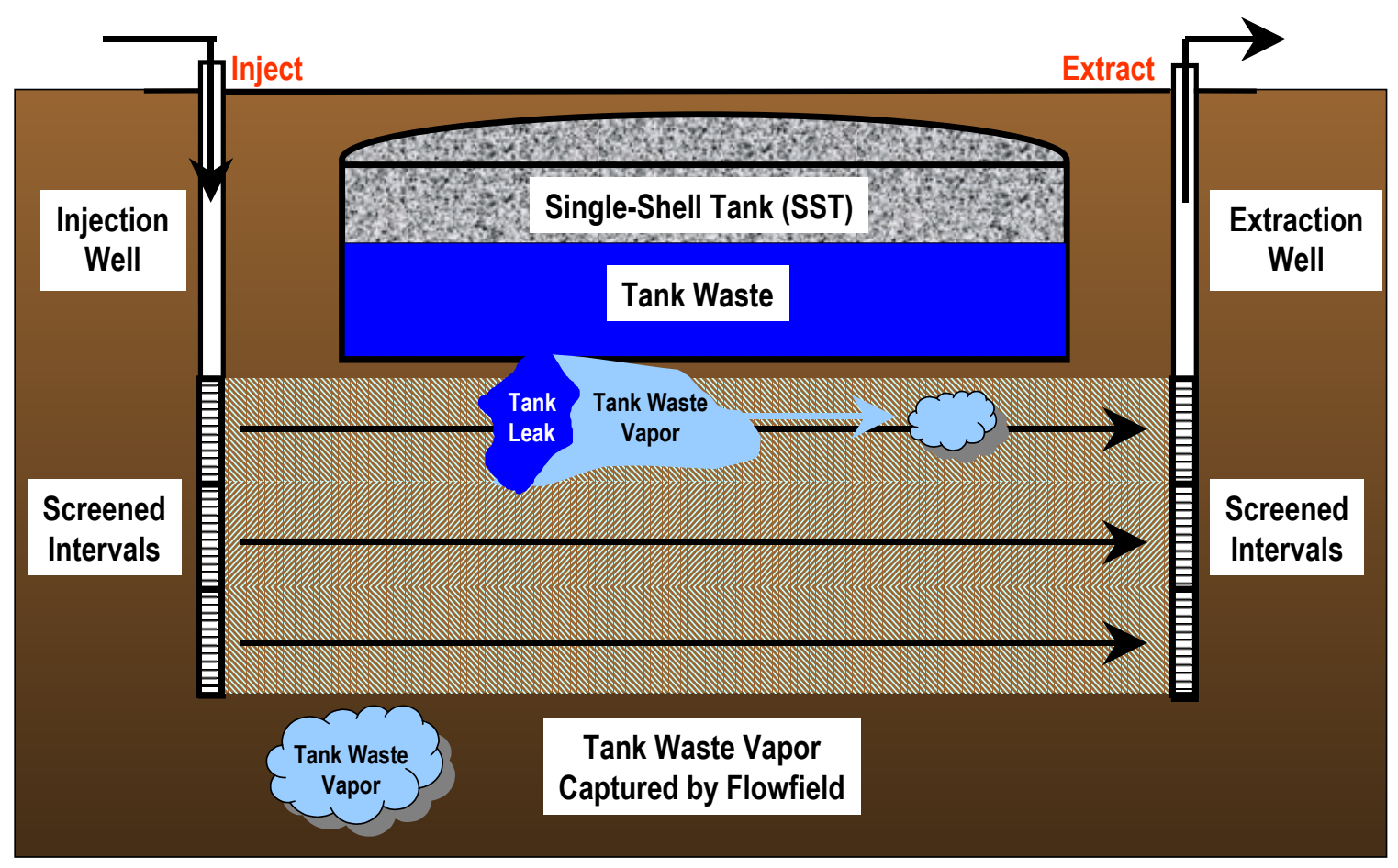

Figure E.3. Tank Waste Vapors 


\section{E.3 Reactive Tracers}

Reactive tracers that change chemically or are consumed when in contact with tank waste may be able to be used for leak detection and monitoring in a manner similar to the partitioning tracer method (see Figure E.4).



Figure E.4. Reactive Tracers

\section{E.4 In Situ Gaseous Reduction}

In situ gaseous reduction (ISGR) involves the use of chemically reactive gas mixtures (hydrogen sulfide in air or nitrogen) to reduce and immobilize contaminants (Figure E.5). This technology has been successfully demonstrated in the laboratory and the field for the immobilization of chromium in the vadose zone at the White Sands Missile Range. Preliminary laboratory tests conducted by Pacific Northwest National Laboratory (PNNL) under the Department of Energy's (DOE) Environmental Management Science Program (EMSP) indicate the successful reduction and immobilization of technetium. This technology is envisioned to mitigate tank leaks that have already occurred as well as creating a barrier to remediate potential future leaks. 


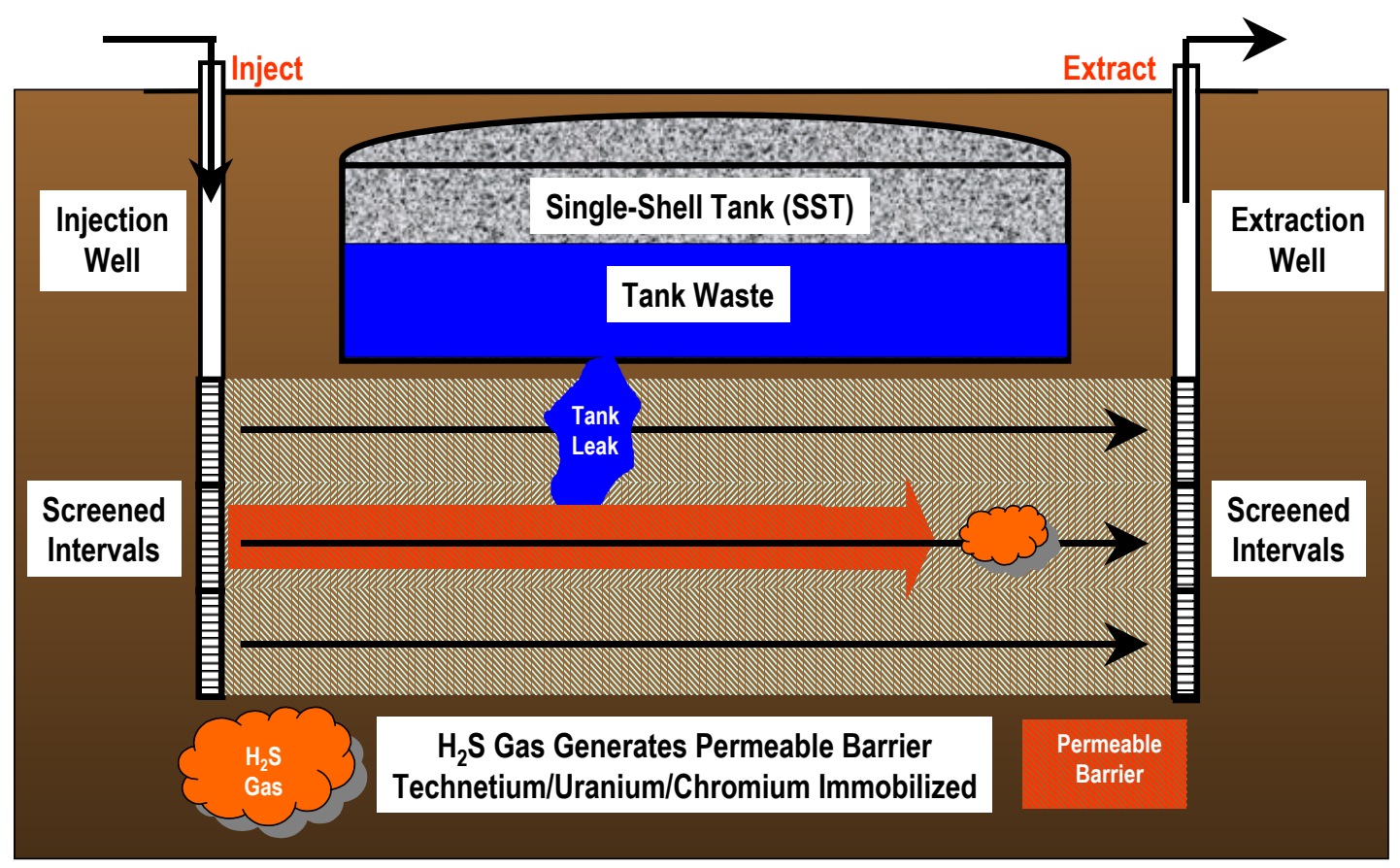

Figure E.5. In Situ Gaseous Reduction

\section{E.5 Interfacial Tracers}

Interfacial tracers may provide characterization data on the subsurface environment that can be used for improving application of other technologies and as input to transport and risk modeling (Figure E.6).

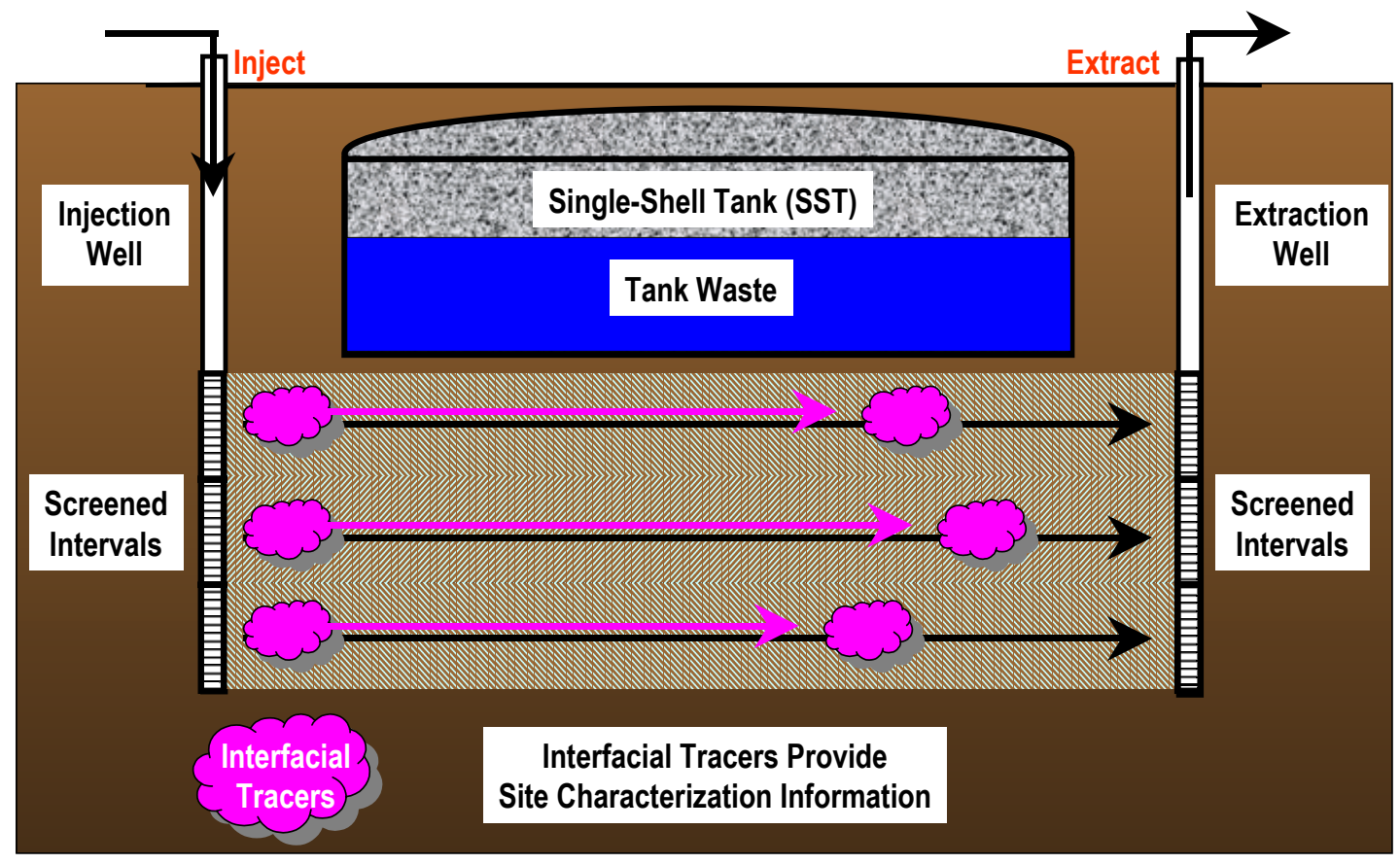

Figure E.6. Interfacial Tracers 


\section{Appendix F}

Detailed Chronology of SAFE Events Conducted in FY 2001 


\section{Appendix F}

\section{Detailed Chronology of SAFE Events Conducted in FY 2001}

\section{F.1 Summary of Events Conducted at the Infiltration Gallery from 7-15-01 to 7-17-01}

The infiltration gallery (IG) is located in the far southeast corner of the Technology Development Area (TDA) (see Figure 4.2 in the main report) and consists of five wells in a single grouping. The grouping has one well in the center with three wells situated $4 \mathrm{ft}$ from the center and equidistant from each other: The one to the north is labeled well $\mathrm{A}$, the one to the southwest is well $\mathrm{B}$, and the one to the southeast is well D. The fifth well is $2 \mathrm{ft}$ south of the center well and labeled well C. All five wells were installed with the cone penetrometer (CPT) and are completed with 2-in.-diameter PVC.

The center well is $8 \mathrm{ft}$ deep and screened over the lowermost $3 \mathrm{ft}$. This well was used as the injection point for a water infiltration test. Wells $\mathrm{A}, \mathrm{B}, \mathrm{C}$, and D are $40 \mathrm{ft}$ deep with no screened intervals. These wells were used for logging with the neutron probe.

\section{Infiltration Test}

The infiltration test was run to ascertain the approximate infiltration rate at which the proposed leak solution of sodium thiosulfate would penetrate the subsurface. This information was then used to prepare for the leak tests at the Mock Tank Structure. For the IG test, 350 gal of sodium thiosulfate was prepared in advance, then injected over a period of 30 hours into well $\mathrm{C}$. The neutron probe was then lowered into wells A, B, C, and D at regular intervals and times to record the movement of the sodium thiosulfate. Table F. 1 contains a chronology for the infiltration test.

Table F.1. Chronology for the IG Infiltration Test

\begin{tabular}{|c|c|c|}
\hline Date and time & $\begin{array}{l}\text { ime from sta } \\
\text { of test (hr) }\end{array}$ & Activity \\
\hline $7 / 16 / 0111: 32$ & 0.00 & $\mathrm{Na}_{2} \mathrm{~S}_{2} \mathrm{O}_{3}\left(\mathrm{H}_{2} 0\right) 5$ solution injection start $(.43 \mathrm{gal} / \mathrm{min})$ \\
\hline 7/16/01 11:52 & 0.33 & Solution injection interrupted due to wellhead overflow \\
\hline 7/16/01 11:57 & 0.42 & Solution injection resumed $(0.38 \mathrm{gal} / \mathrm{min})$ \\
\hline $7 / 16 / 0112: 25$ & 0.88 & Solution injection adjusted ( $0.40 \mathrm{gal} / \mathrm{min})$ \\
\hline $7 / 16 / 0112: 55$ & 1.38 & Solution injection adjusted $(0.34 \mathrm{gal} / \mathrm{min})$ \\
\hline 7/16/01 15:00 & 3.47 & Solution injection adjusted $(0.29 \mathrm{gal} / \mathrm{min})$ \\
\hline 7/17/01 17:30 & 29.97 & $\mathrm{Na}_{2} \mathrm{~S}_{2} \mathrm{O}_{3}\left(\mathrm{H}_{2} \mathrm{O}\right) 5$ solution injection end (400 gal read injected from totalizer) \\
\hline
\end{tabular}




\section{F.2 Summary of Events Conducted at the TDA from 7-23-01 to 8-1-01}

The TDA is due east of the Mock Tank Structure. It was used for development and preliminary testing of the Subsurface Air Flow and Extraction (SAFE) technologies prior to demonstration at the Mock Tank Structure. A linear array of wells was installed down the center of the TDA. It consists of seven wells placed at 15 - $\mathrm{ft}$ intervals in a linear array from east to west. The individual wells were numbered in ascending order starting with the westernmost as well 1.

Wells 1, 3, 5, and 7 are 2-in. CPT boreholes that are $35 \mathrm{ft}$ deep. They are cased with PVC and screened over the lowermost $10 \mathrm{ft}$. These wells were used interchangeably for subsurface air flow injection and extraction and tracer gas injection during the SAFE activities. Wells 2, 4, and 6 are 2-in. boreholes that are $8 \mathrm{ft}$ deep. They are lined with PVC and have screened intervals for the lowermost $3 \mathrm{ft}$. These wells served as injection points for the leak simulants, which include water and sodium thiosulfate.

An airtight canvas and plastic tarp was laid over the liner array to seal the subsurface. The edges of the tarp extend about $15 \mathrm{ft}$ from the wells in all directions. Six-in.-wide plastic tape was used to seal the tarp adjacent to the holes cut in it for the wellheads.

\section{F.2.1 Neon Conservative Interwell Tracer Test}

A conservative interwell tracer test (CITT) was run to identify the amount of neon tracer gas that could predictably be recovered during actual tests in the subsurface below the TDA and Mock Tank Structure. For this test, the injection blower was connected via 2-in. PVC piping to well 1 at the western end of the linear array and the extraction blower was connected via 2-in. PVC piping to well 3, which is $30 \mathrm{ft}$ east of well 1 . The tracer gas was injected into the air stream flowing into well 1 , and the gas chromatograph (GC) was connected via $1 / 4$-in. copper sampling line to the wellhead of well 3 . Table F.2 contains a chronology of the neon CITT.

Table F.2. Chronology for Neon CITT

\begin{tabular}{|c|c|c|}
\hline Date and time & $\begin{array}{l}\text { ime from sta } \\
\text { of test (hr) }\end{array}$ & Activity \\
\hline 7/23/01 8:20 & -3.47 & $\begin{array}{l}\text { Flowfield established at } 14 \mathrm{cfm} \text { nominal injecting into well \#1 and } 24 \mathrm{cfm} \text { nominal } \\
\text { extracting from well \#3 }\end{array}$ \\
\hline 7/23/01 8:45 & -3.05 & $\begin{array}{l}\text { Flowfield adjusted to } 19 \mathrm{cfm} \text { nominal injecting into well } \# 1 \text { and } 24 \mathrm{cfm} \text { nominal } \\
\text { extracting from well } \# 3\end{array}$ \\
\hline 7/23/01 11:44 & -0.07 & Data collection started (file CITT_3) \\
\hline 7/23/01 11:48 & 0.00 & Tracer injection started, neon $(5 \mathrm{~L} / \mathrm{min})$ \\
\hline $7 / 23 / 0112: 00$ & 0.20 & $\begin{array}{l}\text { Flowfield adjusted to } 17 \mathrm{cfm} \text { nominal injecting into well } \# 1 \text { and } 25 \mathrm{cfm} \text { nominal } \\
\text { extracting from well } \# 3\end{array}$ \\
\hline $7 / 23 / 0112: 28$ & 0.67 & $\begin{array}{l}\text { Flowfield adjusted to } 20 \mathrm{cfm} \text { nominal injecting into well } \# 1 \text { and } 25 \mathrm{cfm} \text { nominal } \\
\text { extracting from well } \# 3\end{array}$ \\
\hline 7/23/01 12:48 & 1.00 & Tracer injection ended, neon \\
\hline 7/24/01 8:20 & 20.53 & Data collection interrupted to transfer data to an analysis computer, this CITT ended \\
\hline
\end{tabular}




\section{F.2.2 TDA Baseline Partitioning Interwell Tracer Test}

A baseline partitioning interwell tracer test (PITT) was run to establish a baseline of tracer retardation factors for a battery of tracers. Methane, chlorofluoromethane, pentafluoroethane, and difluoromethane were the tracer gases tested. The injection blower was connected to well 1 via 2 -in. PVC piping, and the tracers were injected into the air stream in the piping at the blower. The extraction blower was connected to well 3, $30 \mathrm{ft}$ east of well 1, via 2 -in. PVC piping. The GC was fed by a $1 / 4$-in. copper sample line connected to well 3 at the wellhead. Table F.3 contains a chronology for the TDA baseline PITT.

Table F.3. Chronology for TDA Baseline PITT

\begin{tabular}{|c|c|c|}
\hline Date and time & $\begin{array}{l}\text { me from sta } \\
\text { of test (hr) }\end{array}$ & 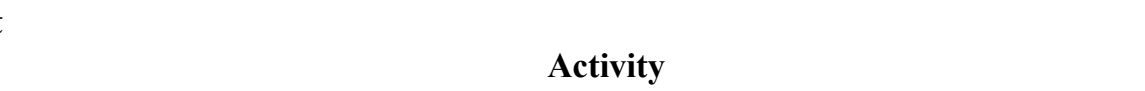 \\
\hline $7 / 26 / 019: 45$ & -0.18 & $\begin{array}{l}\text { Flowfield established at } 22 \mathrm{cfm} \text { nominal injecting into well } 1 \text { and } 24 \mathrm{cfm} \text { nominal } \\
\text { extracting from well } 3\end{array}$ \\
\hline 7/26/01 9:56 & 0.00 & $\begin{array}{l}\text { Tracer injection start, methane, chlorofluoromethane, pentafluoroethane, and } \\
\text { difluoromethane }\end{array}$ \\
\hline 7/26/01 10:56 & 1.00 & $\begin{array}{l}\text { Tracer injection end, methane, chlorofluoromethane, pentafluoroethane, and } \\
\text { difluoromethane }\end{array}$ \\
\hline 7/26/01 11:00 & 1.07 & Data collection started \\
\hline $7 / 26 / 0112: 20$ & 2.40 & $\begin{array}{l}\text { Flowfield adjusted to } 19 \mathrm{cfm} \text { nominal injecting into well } 1 \text { and } 24 \mathrm{cfm} \text { nominal } \\
\text { extracting from well } 3\end{array}$ \\
\hline $7 / 27 / 018: 14$ & 22.30 & $\begin{array}{l}\text { Flowfield adjusted to } 22 \mathrm{cfm} \text { nominal injecting into well } 1 \text { and } 24 \mathrm{cfm} \text { nominal } \\
\text { extracting from well } 3\end{array}$ \\
\hline $7 / 27 / 0114: 57$ & 29.02 & Data collection interrupted to perform well flowrate tests \\
\hline $7 / 27 / 0115: 42$ & 29.77 & Data collection resumed \\
\hline $7 / 29 / 0112: 00$ & 74.07 & Data collection ended, this test complete \\
\hline
\end{tabular}

\section{F.2.3 TDA In-Tank Tracer Test with Nitrous Oxide}

An in-tank tracer test (ITTT) was run to test the detection behavior of a tracer gas sparged into a liquid leaked in the midst of a subsurface air flow interwell arrangement similar to that proposed for the Mock Tank Structure. The injection blower was connected to the easternmost well, 7, with 2-in. PVC piping. The extraction blower was connected to well 5, $30 \mathrm{ft}$ west of well 7, with 2-in. PVC piping. The leak, 400 gal of water sparged with nitrous oxide, was injected into well 6. Table F.4 contains a chronology for the TDA ITTT with nitrous oxide.

Table F.4. Chronology for TDA ITTT

\begin{tabular}{|c|c|c|}
\hline $\begin{array}{l}\text { Date and } \\
\text { time }\end{array}$ & $\begin{array}{l}\text { Time from start } \\
\text { of test (hr) }\end{array}$ & Activity \\
\hline $7 / 29 / 0116: 45$ & -7.00 & Sparging began with $\mathrm{N}_{2} \mathrm{O}(4 \mathrm{~L} / \mathrm{min})$ \\
\hline 7/29/01 21:57 & -1.80 & $\begin{array}{l}\text { Flowfield established at } 8 \mathrm{cfm} \text { nominal injecting into well } 7 \text { and } 10 \mathrm{cfm} \text { nominal } \\
\text { extracting from well } 5\end{array}$ \\
\hline $7 / 29 / 0123: 45$ & 0.00 & Leak of water sparged with $\mathrm{N}_{2} \mathrm{O}$ began \\
\hline 7/30/01 0:00 & 0.25 & Leak of water sparged with $\mathrm{N}_{2} \mathrm{O}$ interrupted by loose hose connection \\
\hline 7/30/01 0:15 & 0.50 & Leak of water sparged with $\mathrm{N}_{2} \mathrm{O}$ resumed $(15.1 \mathrm{gal} / \mathrm{hr})$ \\
\hline $7 / 30 / 011: 15$ & 1.50 & Leak of water sparged with $\mathrm{N}_{2} \mathrm{O}$ ended \\
\hline 7/30/01 8:00 & 8.25 & $\begin{array}{l}\text { Flowfield adjusted to } 11 \mathrm{cfm} \text { nominal injecting into well } \# 7 \text { and } 14 \mathrm{cfm} \text { nominal } \\
\text { extracting from well } 5\end{array}$ \\
\hline
\end{tabular}




\section{F.3 Summary of PITTs at Mock Tank Structure from 8-9-01 to 8-30-01}

Nine wells were used for SAFE experiments conducted on the Mock Tank Structure. These wells are positioned in three clusters of three wells each around the 50-ft-diameter tank. Within the cluster, the wells are $5 \mathrm{ft}$ apart. Each group consists of 4-in. wells drilled to 20,30 and $40 \mathrm{ft}$ bgs, with the bottom $10 \mathrm{ft}$ screened for air injection and extraction. The individual wells were labeled to reflect their screened interval and function. All three clusters were arranged in a line passing through the center of the Mock Tank Structure.

The first well cluster is east of the Mock Tank Structure, $5 \mathrm{ft}$ outside the edge of the tank. They are connected to the injection blowers by PVC pipe reduced from 4- to 2-in. diameter at the wellhead with magnahelic gauges reading the injection flow rate via differential pressure on pitot tubes in the PVC pipe $4 \mathrm{ft}$ from the wellhead. This group served as injection wells. They fed air into the ground and provided carrier air for the input of tracer gas slugs. They were labeled 1020I (injection well screened from 10 to $20 \mathrm{ft}$ bgs), 2030I (injection well screened from 20 to $30 \mathrm{ft} \mathrm{bgs}$ ), and 3040I (injection well screened from 30 to $40 \mathrm{ft}$ bgs).

The second well cluster is west of the Mock Tank Structure, $5 \mathrm{ft}$ outside the edge of the tank. The wells are capped with 4 -in.-diameter PVC caps. Copper tubing ( $1 / 4$ in. inner diameter) was fitted to the wellhead caps for sampling lines, and a small vacuum pump provided a 4- to 8-cfm flow. The vacuum pump maintained a low flow sufficient to draw a small sample from the airstreams passing under the tank. These were labeled 1020M (monitoring well screened from 10 to $20 \mathrm{ft} \mathrm{bgs}$ ), 2030M (monitoring well screened from 20 to $30 \mathrm{ft} \mathrm{bgs}$ ), and 3040M (monitoring well screened from 30 to $40 \mathrm{ft}$ bgs).

The third cluster of wells is west of the Mock Tank Structure and about $10 \mathrm{ft}$ outside the edge of the tank, outboard of the monitoring well cluster. These wells were connected to the extraction blowers via PVC pipe reduced from 4- to 2-in. in diameter at the wellhead. Magnahelic gauges monitored the extraction flowrate by reading differential pressure on the pitot tubes in the pipe $4 \mathrm{ft}$ from the wellhead. Copper sampling lines ( $1 / 4$ in. inner diameter) were fit within the 2-in. PVC leading to the extraction blowers $25 \mathrm{ft}$ from the wellhead. These extraction wells provided the vacuum needed for the subsurface air flow and samples for the GC. The wells are labeled 1020E (extraction well screened from 10 to $20 \mathrm{ft}$ bgs), 2030E (extraction well screened from 20 to $30 \mathrm{ft}$ bgs), and 3040E (extraction well screened from 30 to $40 \mathrm{ft} \mathrm{bgs}$ ).

Airtight canvas and plastic tarps were used on the ground surface to restrict the air exchange with the subsurface. A ring of tarps was laid around the Mock Tank Structure from the edge of the tank wall $10 \mathrm{ft}$ out. A 50-ft-diameter circular tarp was laid across the entire internal surface of the Mock Tank Structure. Two 20- $\mathrm{x} 30$ - $\mathrm{ft}$ tarps were laid adjacent to the ring of tarps around the tank edge directly outboard of the well groups. All of the tarps were sealed to the Mock Tank Structure with 6 in.-wide heavy plastic tape. Holes were cut to facilitate wellheads where applicable.

\section{F.3.1 Individual SAFE Tests}

Each of the SAFE tests revolved around the schedule for simulated leaks at the Mock Tank Structure. These leaks were relatively close together in time, and all were leaked from the same location at the center of the Mock Tank Structure. This meant that the leak solution of sodium thiosulfate accumulated 
under the tank over time. While some solution may have infiltrated deeper than the screened interval of the deepest wells, 30 to $40 \mathrm{ft}$ bgs, some was assumed to remain during subsequent leaks.

\section{F.3.2 Baseline PITT}

The baseline PITT was undertaken to establish the baseline behavior of the partitioning tracer gases before injection of the sodium thiosulfate. Table F.5 contains a chronology for the Mock Tank Structure baseline PITT.

Table F.5. Chronology for Mock Tank Structure Baseline PITT

\section{Elapsed Time}

$\begin{array}{ccl}\begin{array}{c}\text { Date, time } \\ \text { 8/7/01 16:00 }\end{array} & \begin{array}{c}\text { Ahr) } \\ \text {-4.00 }\end{array} & \begin{array}{l}\text { Activity } \\ \text { Flowfield established, } 50 \text { cfm nominal per screened interval, 150 cfm nominal total } \\ \text { for all screened intervals, for both injection and extraction wells. }\end{array} \\ \text { 8/7/01 20:00 } & 0.00 & \begin{array}{l}\text { Data collection commenced, file named "base". } \\ \text { 8/7/01 20:00 }\end{array} \\ \text { 8/7/01 20:30 } & 0.00 & \begin{array}{l}\text { Tracer injection start, methane and chlorofluoromethane. } \\ \text { 8/8/01 4:20 }\end{array} \\ \text { 8/8/01 10:00 } & 8.33 & \begin{array}{l}\text { Tracer injection end, methane (125 gal total injected) and chlorofluoromethane. } \\ \text { Data collection interrupted by computer illegal operation error. }\end{array} \\ \text { 8/8/01 16:50 } & 20.83 & \begin{array}{l}\text { Data collection resumed. } \\ \text { Data collection ended, flowfield terminated }\end{array}\end{array}$

\section{F.3.3 ITTT-1}

ITTT-1 was conducted concurrent with the first leak of sodium thiosulfate of unknown quantity, thought to be 800 to 1200 gal. The leak started while the ITTT was already taking place. For this ITTT, a 50/50 mixture of difluoromethane and pentafluoroethane tracer was sparged into the sodium thiosulfate leak solution. No leak solution was in the ground prior to this test. Monitoring for ITTT-1 continued through PITT-2 and PITT-3. Table F.6 contains a chronology of the Mock Tank Structure ITTT-1.

Table F.6. Chronology for Mock Tank Structure ITTT-1

\section{Elapsed}

Date, time Time (hr)

$8 / 8 / 0111 \cdot 00$ $-21.50$

$-13.00$

Activity

$8 / 8 / 0119: 30$

8/9/01 6:30

$-2.00$

Began to sparge ITT of at $8 \mathrm{~L} / \mathrm{min}$, difluoromethane and pentafluoroethane

$8 / 9 / 017: 30$

$8 / 9 / 017: 30$

$8 / 9 / 017: 50$

8/9/01 8:30

0.00

Sparging of ITT flow increased to $18 \mathrm{~L} / \mathrm{min}$, difluoromethane and pentafluoroethane

Flowfield established, $80 \mathrm{cfm}$ nominal per screened interval, $240 \mathrm{cfm}$ nominal total for all screened intervals for injection wells, $120 \mathrm{cfm}$ nominal per screened interval, $360 \mathrm{cfm}$ nominal total for all screened intervals for extraction wells.

$8 / 9 / 0111: 20$

Data collection began, file named "1PITT." Sparging of ITT increased to maximum available flow, difluoromethane.

-0.67 Flowfield changed from 80 to $50 \mathrm{cfm}$ nominal per screened interval and from $240 \mathrm{cfm}$ nominal total for all screened intervals for injection wells, $110 \mathrm{cfm}$ nominal per screened interval, and $330 \mathrm{cfm}$ nominal total for all intervals for extraction wells to $150 \mathrm{cfm}$ total for all screened intervals for both injection and extraction wells.

2.83 Sparging of ITT set to $8 \mathrm{~L} / \mathrm{min}$, difluoromethane and pentafluoroethane. 
Table F.6. Chronology for Mock Tank Structure ITTT-1

\begin{tabular}{|c|c|c|}
\hline Date, time & $\begin{array}{c}\text { Elapsed } \\
\text { Time (hr) }\end{array}$ & Activity \\
\hline 8/9/01 13:30 & 5.00 & $\begin{array}{l}\text { Flowfield changed from } 50 \mathrm{cfm} \text { nominal per screened interval, } 150 \mathrm{cfm} \text { nominal total for } \\
\text { all screened intervals to } 10 \mathrm{cfm} \text { nominal per screened interval, } 30 \mathrm{cfm} \text { nominal total for all } \\
\text { screened intervals for both injection and extraction wells. }\end{array}$ \\
\hline 8/9/01 16:10 & 7.67 & Sparging of ITT set to $9 \mathrm{~L} / \mathrm{min}$, difluoromethane. \\
\hline $\begin{array}{l}\text { 8/9/01 23:00- } \\
8 / 10 / 018: 00\end{array}$ & 14.50 & $\begin{array}{l}\text { Flowfield to wells } 2030 \mathrm{E} \text { and } 3040 \mathrm{E} \text { lost during the night at an unknown time between 8- } \\
\text { 9-01, 23:00 and 8-10-01 08:00 due to diesel generator failure. }\end{array}$ \\
\hline 8/10/01 8:30 & 24.00 & $\begin{array}{l}\text { Flowfield to wells } 2030 \mathrm{I} \text { and } 3040 \mathrm{I} \text { shut down. Flowfield left at } 10 \mathrm{cfm} \text { nominal per } \\
\text { screened interval (only well } 1020 \mathrm{I}), 10 \mathrm{cfm} \text { total for all screened intervals for injection } \\
\text { wells, and } 10 \mathrm{cfm} \text { per screened interval (only well } 1020 \mathrm{E} \text { ), } 10 \mathrm{cfm} \text { nominal total for all } \\
\text { screened intervals for extraction wells. }\end{array}$ \\
\hline 8/10/01 13:30 & 29.00 & $\begin{array}{l}\text { Flowfield re-established to all wells, set at } 10 \mathrm{cfm} \text { nominal per screened interval, } 30 \mathrm{cfm} \\
\text { nominal total for all screened intervals for both injection and extraction wells. }\end{array}$ \\
\hline $8 / 10 / 0114: 28$ & 29.97 & Tracer injection started, flow set at $5 \mathrm{~L} / \mathrm{min}$, neon. \\
\hline 8/10/01 14:59 & 30.48 & Tracer injection ended, neon \\
\hline $8 / 10 / 0115: 30$ & 31.00 & Flowfield lost to both injection a \\
\hline 8/10/01 16:00 & 31.50 & $\begin{array}{l}\text { Flowfield reestablished to both injection and extraction wells by switching to backup } \\
\text { blowers, flow rates set to } 10 \mathrm{cfm} \text { nominal per screened interval, } 30 \mathrm{cfm} \text { nominal total for } \\
\text { all screened intervals for both injection and extraction wells. }\end{array}$ \\
\hline 8/11/01 8:30 & 48.00 & $\begin{array}{l}\text { Printing of data stopped overnight due to printer failure. Sample files 1Pitt531 through } \\
\text { 1Pitt564 did not print. }\end{array}$ \\
\hline 8/11/01 11:00 & 50.50 & Data collection interrupted due to computer illegal operation error. \\
\hline 8/11/01 11:53 & 51.38 & Data collection resumed. \\
\hline 8/11/01 13:30 & 53.00 & Sparging of ITT set to $8 \mathrm{~L} / \mathrm{min}$, difluoromethane. \\
\hline $8 / 11 / 01 \quad 15: 20$ & 54.83 & $\begin{array}{l}\text { Data collection interrupted by GC failing due to excessive heat in the trailer; air } \\
\text { conditioning fails, file "1PITT." }\end{array}$ \\
\hline $8 / 11 / 0116: 26$ & 55.93 & Data collection resumed, file named "1Leak." \\
\hline 8/12/01 6:30 & 70.00 & Flowfield interrupted to extraction wells due to generator failure. \\
\hline 8/12/01 7:00 & 70.50 & Flowfield restored to extraction wells by generator restart \\
\hline $8 / 12 / 0115: 15$ & 78.75 & $\begin{array}{l}\text { Monitoring wells } 1020 \mathrm{M}, 2030 \mathrm{M} \text {, and } 3040 \mathrm{M} \text { lost vacuum pressure due to electrical short, } \\
\text { cutting power to their small pumps. }\end{array}$ \\
\hline$/ 12 / 0116: 30$ & 80.00 & Data collection ended for this ITT, file "1LEAK." \\
\hline
\end{tabular}

\section{F.3.4 PITT-2}

The injection of the first simulated leak into the subsurface below the Mock Tank Structure continued through the beginning of PITT-2 and ended partway through. A second simulated leak injection began during PITT-2 and ended shortly afterward. For this PITT, methane and chlorofluoromethane were used as conservative and partitioning tracers, respectively. Table F.7 contains a chronology of the Mock Tank Structure PITT-2. 
Table F.7. Chronology for Mock Tank Structure PITT-2

Elapsed ITTT-1

Date, time Time (hr) Time (hr)

$8 / 12 / 0116: 50 \quad-0.95 \quad 80.33$

total for all screened intervals for both injection and extraction wells.

8/12/01 17:00 -0.78 $\quad 80.50$ Tracer injection started, methane and chlorofluoromethane. Data collection began,

8/12/01 17:15 $\quad-0.53 \quad 80.75$ Tracer injection interrupted due to tracer lines feeding the wrong pipes, methane

and chlorofluoromethane.

8/12/01 17:47 $\quad 0.00 \quad 81.28$ Tracer injection resumed plumbed to the correct pipes, methane and chloro-

8/12/01 17:51 $\quad 0.07 \quad 81.35$ Peaksimple showed good flow of tracer into the flowfield (Peaksimple was connected to the injection wells, not the extraction wells, at this time, and monitoring wells while conducting "injection sampling.")

8/12/01 18:47 $\quad 1.00 \quad 82.28 \quad$ Tracer injection stopped (250 gal injected), methane and chlorofluoromethane (586 gal injected).

8/12/01 19:00 1.22

8/12/01 19:15 1.47

$8 / 12 / 0120: 45 \quad 2.97$

8/13/01 8:30

14.72

$8 / 13 / 0114: 15 \quad 20.47$

8/13/01 14:33 20.77

8/13/01 19:00

25.22

8/13/01 23:00

8/13/01 23:40

8/14/01 12:00

8/15/01 12:50

8/15/01 13:00

8/16/01 8:30

8/16/01 15:20
29.22

29.88

42.22

67.05

67.22

86.72

93.55
82.50

increased from $50 \mathrm{cfm}$ nominal per screened interval, $150 \mathrm{cfm}$ nomina total for all screened intervals to $70 \mathrm{cfm}$ nominal per screened interval, $210 \mathrm{cfm}$ nominal total for all screened intervals for both injection and extraction wells.

82.75 Flowfield interrupted for injection wells only by diesel generator overheating (ambient temperature was over $100^{\circ} \mathrm{F}$.) Flowfield left at $50 \mathrm{cfm}$ nominal, $150 \mathrm{cfm}$ nominal total for all screened intervals for extraction wells only.

84.25 Flowfield for injection wells restored, flow rate of $50 \mathrm{cfm}$ nominal per screened interval, $150 \mathrm{cfm}$ nominal total for all screened intervals set for both injection and extraction wells.

96.00 Simulated leak 1 ended. blower, which had been melting with a stainless steel section. Flowfield left at $50 \mathrm{cfm}$ nominal per screened interval, $150 \mathrm{cfm}$ nominal total for all screened intervals for extraction wells only.

102.05 Flowfield for injection wells restored by replacing PVC pipe next to blower with a galvanized steel section, flowfield set to $50 \mathrm{cfm}$ nominal per screened interval, 150 $\mathrm{cfm}$ nominal total for all screened intervals for both injection and extraction wells.

106.50 Equipment in lab trailer required constant attention due to excessive heat $\left(105^{\circ} \mathrm{F}\right.$ + ); the air conditioning had quit working. No data loss.

110.50 Data collection interrupted by computer failure (excessive heat), file "2PITT."

111.17 Data collection restored, file "2PITT."

123.50 Simulated leak 2 started.

148.33 Data collection stopped, file "2PITT."

148.50 Data collection restarted, new file named "2aPITT."

168.00 Data collection interrupted by computer restart error, file "2aPITT." Data collection stopped.

174.83 Simulated leak 2 ended.
101.75 Flowfield interrupted for injection wells only to replace PVC pipe from injection 


\section{F.3.5 PITT-3}

PITT-3 was run concurrently with a simulated leak expected to be a fixed volume of about 500 gal of sodium thiosulfate in one continuous injection prior to the beginning of the PITT. The gases used in this PITT were methane and chlorofluoromethane as conservative and partitioning tracers, respectively. At this point there has been an expected total leak volume of 1300 to 1700 gal of sodium thiosulfate injected into the subsurface directly under the Mock Tank Structure. Tank F.8 contains a chronology for the Mock Tank Structure PITT-3.

Table F.8. Chronology for the Mock Tank Structure PITT-3

\section{Elapsed ITTT-1}

Date, time Time (hr) Time (hr)

\begin{tabular}{|c|c|c|c|}
\hline $8 / 16 / 0115: 20$ & -17.42 & 174.83 & Simulated leak 2 A started. \\
\hline $8 / 17 / 017: 00$ & -1.75 & 190.50 & $\begin{array}{l}\text { Flowfield established at } 50 \mathrm{cfm} \text { nominal per screened interval, } 150 \mathrm{cfm} \text { nominal } \\
\text { total for all screened intervals for both injection and extraction wells. }\end{array}$ \\
\hline 8/17/01 8:30 & -0.25 & 192.00 & Simulated leak $2 A$ ended. \\
\hline $8 / 17 / 018: 45$ & 0.00 & 192.25 & $\begin{array}{l}\text { Tracer injection started, methane and chlorofluoromethane. Data collection } \\
\text { started, "3PITT," for injection sampling. }\end{array}$ \\
\hline 8/17/01 9:15 & 0.50 & 192.75 & $\begin{array}{l}\text { Tracer injection ended, methane ( } 125 \text { gal injected) and chlorofluoromethane } \\
\text { (293 gal injected). }\end{array}$ \\
\hline $17 / 0110: 20$ & 1.58 & 193.83 & $\begin{array}{l}\text { Data collection interrupted by power loss due to diesel generator failure to the } \\
\text { analytical equipment in the lab trailer for file named "3PITT." }\end{array}$ \\
\hline $8 / 17 / 0113: 00$ & 4.25 & 196.50 & Data collection restored with new power source to lab trailer, file "3РITT." \\
\hline 8/17/01 18:00 & 9.25 & 201.50 & The wind became very high and shook lab trailer housing analytical equipment. \\
\hline $8 / 18 / 012: 30$ & 17.75 & 210.00 & The wind died down. \\
\hline $8 / 18 / 0113: 10$ & 28.42 & 220.67 & Data collection interrupted by computer illegal operation error, file "3PITT." \\
\hline $8 / 18 / 0114: 25$ & 29.67 & 221.92 & $\begin{array}{l}\text { Data collection partially restored, file "3PITT." No files were saved for the } \\
\text { samples taken from "3PITT111" on. }\end{array}$ \\
\hline 8/18/01 15:20 & 30.58 & 222.83 & Data collection interrupted to reset computer, file "3PITT." \\
\hline $8 / 18 / 0116: 20$ & 31.58 & 223.83 & Data collection restored, new file named "3aPITT." \\
\hline $8 / 18 / 0117: 45$ & 33.00 & 225.25 & High wind returned and shook lab trailer and analytical equipment again. \\
\hline $8 / 19 / 011: 30$ & 40.75 & 233.00 & The wind abated. \\
\hline $8 / 20 / 0111: 00$ & 74.25 & 266.50 & Data collection stopped, file "3aPITT." Flowfield stopped. \\
\hline
\end{tabular}

\section{F.3.6 ITTT-2}

Prior to ITTT-2, another simulated leak injection was conducted between test activities and was expected to be about 500 gal. ITTT-2 took place during the subsequent simulated leak injection of uncertain volume into the subsurface below the Mock Tank Structure. Chlorodifluoromethane was used as an in-tank tracer to demonstrate early detection of this simulated leak. Table F.9 contains a chronology for the Mock Tank Structure ITTT-2. 
Table F.9. Chronology for the Mock Tank Structure ITTT-2

\begin{tabular}{|c|c|c|}
\hline Date, time & $\begin{array}{l}\text { apsed T } \\
\text { (hr) }\end{array}$ & Activity \\
\hline $8 / 20 / 0112: 00$ & -26.50 & Simulated leak 3 started. \\
\hline 8/21/01 9:00 & -5.50 & Simulated leak 3 ended. \\
\hline $8 / 21 / 0110: 45$ & -3.75 & Sparging of in-tank tracer started with chlorodifluoromethane. \\
\hline $8 / 21 / 0111: 45$ & -2.75 & Sparging of in-tank tracer interrupted with chlorodifluoromethane. \\
\hline $8 / 21 / 0114: 30$ & 0.00 & Simulated leak 4 started. \\
\hline $8 / 21 / 0116: 00$ & 1.50 & $\begin{array}{l}\text { Sparging of in-tank tracer resumed with chlorodifluoromethane bottle full open for } \\
\text { maximum saturation in minimal time. }\end{array}$ \\
\hline $8 / 21 / 0117: 05$ & 2.58 & $\begin{array}{l}\text { Flowfield established at } 50 \mathrm{cfm} \text { nominal per screened interval, } 150 \mathrm{cfm} \text { nominal total for } \\
\text { all screened intervals for both injection wells and extraction wells. }\end{array}$ \\
\hline $8 / 21 / 0117: 30$ & 3.00 & $\begin{array}{l}\text { Data collection started with triple sorbent trap (TST) samples taken by hand every half } \\
\text { hour starting } 1730 \text { and ending } 2000 \text { samples only taken from well } 1020 \mathrm{E} \text {. }\end{array}$ \\
\hline 8/21/01 20:00 & 5.50 & Data collection stopped with TST samples taken by hand. \\
\hline $8 / 21 / 0120: 15$ & 5.75 & Data collection started, file named "4PITT." Sampling well 1020E only. \\
\hline $8 / 22 / 0113: 00$ & 22.50 & Took TST sample by hand from well 1020E. \\
\hline $8 / 22 / 0113: 55$ & 23.42 & Data collection interrupted by switching to backup power supply, file "4PITT." \\
\hline $8 / 22 / 0114: 30$ & 24.00 & Data collection restored, file "4PITT." \\
\hline 8/23/01 9:30 & 43.00 & Data collection stopped, file "4PITT." \\
\hline
\end{tabular}

\section{F.3.7 PITT-5}

PITT-5 started immediately after the final simulated leak injection of uncertain volume leak took place and used tracers of methane and chlorofluoromethane as conservative and partitioning tracers, respectively. The bulk of the sodium thiosulfate leak solution had been injected into the subsurface directly below the Mock Tank Structure and 2300 to 2700 gal should have been in the subsurface by the time the PITT began. The flowfield of $50 \mathrm{cfm}$ per screened interval for both air injection and extraction wells established during ITTT-2 was continued and maintained throughout PITT-5. Table F.10 contains a chronology for the Mock Tank Structure PITT-5.

Table F.10. Chronology for the Mock Tank Structure PITT-5

\section{Elapsed ITTT-2}

\begin{tabular}{|c|c|c|c|}
\hline Date, time & Time (hr) & Time (hr) & Activity \\
\hline $8 / 23 / 0111: 30$ & -1.03 & 45.00 & Data collection started, file named "5PITT." \\
\hline $8 / 23 / 0112: 00$ & -0.53 & 45.50 & Simulated leak 4 ended. \\
\hline $8 / 23 / 0112: 32$ & 0.00 & 46.03 & Tracer injection started, methane and chlorofluoromethane. \\
\hline $8 / 23 / 0113: 02$ & 0.50 & 46.53 & $\begin{array}{l}\text { Tracer injection ended, methane ( } 125 \text { gal injected) and chlorofluoromethane } \\
\text { (421 gal injected). }\end{array}$ \\
\hline $8 / 24 / 013: 15$ & 14.72 & 60.75 & Zeroed the Peaksimple computer. \\
\hline $8 / 24 / 017: 10$ & 18.63 & 64.67 & Zeroed the Peaksimple computer. \\
\hline $8 / 25 / 010: 50$ & 36.30 & 82.33 & Data collection interrupted by power surge, file "5PITT." \\
\hline $8 / 25 / 011: 10$ & 36.63 & 82.67 & Data collection restored, file "5PITT." \\
\hline $8 / 25 / 017: 20$ & 42.80 & 88.83 & $\begin{array}{l}\text { Data collection changed, sampling now only on well } 2030 \mathrm{E} \text { every } 15 \text { minutes, } \\
\text { file "5PITT." }\end{array}$ \\
\hline 8/27/01 9:00 & 92.47 & 138.50 & Simulated leak 5 started. \\
\hline 8/27/01 13:00 & 96.47 & 142.50 & Data collection ended, file "5PITT." Flowfield shut down. \\
\hline
\end{tabular}




\section{F.3.8 PITT-6}

The final PITT at the Mock Tank Structure was conducted using tracers of methane and chlorofluoromethane as conservative and partitioning tracers, respectively, for an unplanned leak injection. The tracer injection method for PITT- 6 was altered from previous PITTs by injecting the tracer without the injection blowers running. The extraction blowers provided sufficient suction to draw the injected tracer volume into the subsurface and slightly toward the extraction wells. Once the tracer injection was complete, the injection blowers were restarted. This action prevented the wide dispersion of tracer gases and confined the tracer slugs to the subsurface beneath the Mock Tank Structure. This simulated leak contained the remainder of the sodium thiosulfate solution from the previous simulated leaks. At the end of this leak, all 4000 gal of the sodium thiosulfate were in the ground. Table F.11 contains a chronology for the Mock Tank Structure PITT-6.

Table F.11. Chronology for the Mock Tank Structure PITT-6

\begin{tabular}{|c|c|c|}
\hline Date, time & $\begin{array}{l}\text { Elapsed } \\
\text { Time (hr) }\end{array}$ & Activity \\
\hline $8 / 28 / 019: 00$ & -3.83 & Simulated leak 5 ended. \\
\hline 8/28/01 11:30 & -1.33 & Data collection started for file "6PITT." \\
\hline $8 / 28 / 0112: 30$ & -0.33 & $\begin{array}{l}\text { Flowfield established at } 50 \mathrm{cfm} \text { nominal per screened interval, } 150 \mathrm{cfm} \text { nominal total for all } \\
\text { screened intervals for extraction wells only. }\end{array}$ \\
\hline $8 / 28 / 0112: 50$ & 0.00 & Tracer injection started, methane and chlorofluoromethane. \\
\hline 8/28/01 13:20 & 0.50 & $\begin{array}{l}\text { Tracer injection ended, methane ( } 125 \text { gal injected) and chlorofluoromethane ( } 494 \text { gal } \\
\text { injected). }\end{array}$ \\
\hline $8 / 28 / 0113: 30$ & & $\begin{array}{l}\text { Flowfield established at } 50 \mathrm{cfm} \text { nominal per screened interval, } 150 \mathrm{cfm} \text { nominal total for all } \\
\text { screened intervals for both injection wells and extraction wells. }\end{array}$ \\
\hline 30/01 11:00 & 46.17 & Data collection ended for file "6PITT." Flowfield shut down. \\
\hline
\end{tabular}

\section{F.3.9 Leak Event Summary}

The holding tank for sodium thiosulfate contained 4000 gal at the beginning of the simulated leak injections. It was completely emptied by a series of simulated leak injections over 20 days. Because the volume of the solution in the subsurface below the Mock Tank Structure before each new simulated leak injection affected the data for each successive activity, the impact of residual sodium thiosulfate in the subsurface may merit consideration. Some of the solution might have infiltrated below the lowest screened interval, ending at $40 \mathrm{ft}$ bgs, interrogated by the SAFE subsurface flowfield. 